\title{
SISTEMA RADICULAR DE CANA-DE-AÇÚCAR E IDENTIFICAÇÃO DE RAÍZES METABOLICAMENTE ATIVAS
}

\section{CARLOS EDUARDO FARONI}

\author{
Dissertação apresentada à Escola Superior de \\ Agricultura “Luiz de Queiroz”, Universidade de São \\ Paulo, para obtenção do título de Mestre em \\ Agronomia, Área de Concentração: Solos e Nutrição \\ de Plantas.
}

P I R A C I C A B A

Estado de São Paulo - Brasil

Novembro - 2004 


\section{SISTEMA RADICULAR DE CANA-DE-AÇÚCAR E IDENTIFICAÇÃO DE RAÍZES METABOLICAMENTE ATIVAS}

\section{CARLOS EDUARDO FARONI}

Engenheiro Agrônomo

Orientador: Prof. Dr. PAULO CESAR OCHEUZE TRIVELIN

Dissertação apresentada à Escola Superior de Agricultura “Luiz de Queiroz”, Universidade de São Paulo, para obtenção do título de Mestre em Agronomia, Área de Concentração: Solos e Nutrição de Plantas.

P I R A C I C A B A

Estado de São Paulo - Brasil

Novembro - 2004 
Dados I nt ernacionai s de Cat al ogação na Publ i cação (CI P) DI VI SÃO DE BI BLI OTECA E DOCUMENTAÇÃO - ESALQI USP

Faroni, Carlos Eduardo

Sistema radicular de cana-de-açúcar e identificação de raízes metabolicamente ativas I Carlos Eduardo Faroni. - - Piracicaba, 2004.

68 p. : il.

Dissertação (Mestrado) - - Escola Superior de Agricultura Luiz de Queiroz, 2004.

Bibliografia.

1. Amostragem 2. Cana-de-açúcar 3. Isótopo estável 4. Manejo do solo 5. Nitrogênio 6. Sistema radicular 7 . Uréia I. Título

CDD 633.61

"Permi tida a cópia total ou parcial deste documento, desde que citada a f ont e - O aut or" 
À minha mãe,

\section{Sílvia}

Pela dedicação a minha formação, por sua fé, seu carinho e AMOR acima de tudo.

Ao meu pai,

José Carlos

Pelo apoio, incentivo e confiança.

Ao meu irmão,

\section{Guto}

Por me mostrar que dividir, muitas vezes, é um ato de somar.

Aos meus avós,

Orlandina, Geraldo, Therezinha e Alcides,

Pela amizade e incentivo.

OFEREÇO.

\section{À Amanda,}

Pela compreensão, confiança, carinho, amizade e, antes de tudo, pelo AMOR. 


\section{AGRADECIMENTOS}

Ao Prof. Dr. Paulo Cesar Ocheuze Trivelin, pela excelente orientação, incentivo, participação e amizade.

Aos professores Dr. Luis Ignácio Prochnow, Dr Jairo Antonio Mazza e Dr. Edgar Gomes Ferreira de Beauclair, pelas críticas e sugestões apresentadas no exame de qualificação.

Ao Prof Dr. Albertino Bendassolli, pelos ensinamentos e pelo apoio.

Ao Prof. Dr. Décio Barbin e a Prof ${ }^{a}$. Dr. Sônia Maria De Stefano Piedade, pelo auxílio nas análises estatísticas.

Ao Conselho do Programa de Pós-Graduação em Solos e Nutrição de Plantas pela confiança.

A CAPES e a FAPESP, pela concessão de bolsa de estudos nos períodos de 03/2003 a 08/2003 e 09/2003 a 02/2005 respectivamente.

A FAPESP pelo financiamento do projeto.

Ao CENA/USP, em especial ao Laboratório de Isótopos Estáveis, pelo suporte científico, técnico e logístico.

Ao Grupo COSAN S/A - Usina Costa Pinto, pela concessão da área experimental e apoio na colheita do experimento.

Ao técnico Palhares, pelo auxílio na escolha da área experimental e apoio nas práticas de campo.

Ao amigo Dr. André Cesar Vitti, pelas idéias na elaboração do projeto e pelo incentivo.

À colega e amiga Mírian Cristina Gomes da Costa, pelo auxílio no momento de dificuldade e por compartilhar das minhas das dúvidas. 
À colega e amiga Aline Genú, pelo auxílio no momento de urgência.

Aos grandes amigos: Anderson Lange, Carlos Roberto Sant'anna, Gleuber Mariano Teixeira, Henrique Junqueira Franco, Isabela Rodrigues Bologna e Tatiele Anete Bergamo Fenilli, por toda ajuda que me deram na realização desse trabalho, pelo convívio harmonioso e pelo companheirismo, em todos os momentos.

Ao colega e amigo Hugo Batagello, pela participação e disposição nas práticas de campo.

Ao amigo e ‘irmão’ João Paulo, pelo convívio, companheirismo e amizade.

À Samira e Jairo Campos de Araújo, pela amizade, compreensão, apoio e incentivo, principalmente nos momentos difíceis.

Aos funcionários do Laboratório de Isótopos Estáveis, em especial ao Bento, Clelber, Juliana, Miguel, Magda e Pingin, pelo convívio amigável e auxilio nas atividades de laboratório e administrativas.

Aos estagiários e ex-estagiários do Laboratório de Isótopos Estáveis: Caroline, Ciro, Felipe, Flávia, Gleison, Priscila e Renato, pelo apoio na realização deste trabalho e pela oportunidade de aprender e ensinar.

Aos amigos tiroleses Sílvio e Fabiano, pela tranqüilidade, responsabilidade e alegria com que colaboraram nas práticas de campo.

Queria agradecer a todas as pessoas aqui não citadas e que fizeram parte de mais este capítulo da minha vida. Agradecer àquelas que me ajudaram e/ou orientaram, vocês, independente do tamanho da participação, já fazem parte da minha história. 


\section{SUMÁRIO}

Página

LISTA DE FIGURAS................................................................................... viii

LISTA DE QUADROS.................................................................................. xi

LISTA DE TABELAS.................................................................................. xii

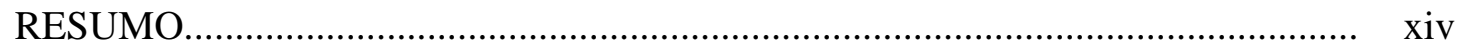

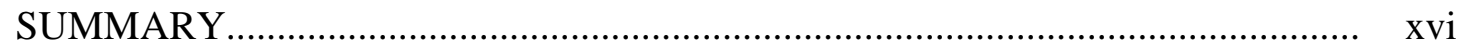

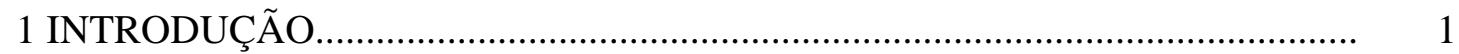

2 REVISÃO DE LITERATURA.......................................................................... 3

2.1 Desenvolvimento e distribuição do sistema radicular da cana-de-açúcar............. 3

2.2 Fatores que influenciam o desenvolvimento do sistema radicular......................... 6

2.3 Avaliação do sistema radicular............................................................................. 7

2.4 Importância do nitrogênio para a cultura da cana-de-açúcar................................. 9

2.5 Métodos de estudo do sistema radicular com traçador isotópico ${ }^{15} \mathrm{~N}$................... 10

2.5.1 Métodos de fornecimento do marcador isotópico ${ }^{15} \mathrm{~N}$ às plantas....................... 11

2.5.2 Fornecimento via foliar, absorção e distribuição da uréia ${ }^{15} \mathrm{~N}$ na planta........... 12

3 MATERIAL E MÉTODOS............................................................................. 15

3.1 Localização da área experimental, variedade de cana-de-açúcar, tipo de solo, manejo e épocas de amostragem......................................................................... 15

3.2 Delineamento e parcelas experimentais.............................................................. 17

3.3 Solução de uréia- ${ }^{15} \mathrm{~N}$ e forma de aplicação......................................................... 18

3.4 Equipamentos utilizados nas amostragens....................................................... 19

3.5 Esquema de coleta de amostras de planta e de solo contendo raízes................... 20

3.6 Processamento do material colhido........................................................................ 21 
3.7 Determinações de N-total e de abundância de ${ }^{15} \mathrm{~N}$.

3.8 Cálculos para quantificação da massa seca de raízes metabolicamente ativas (vivas)

3.9 Pluviosidade e balanço hídrico simplificado durante o desenvolvimento da cana-de-açúcar..

3.10 Análise estatística.

4 RESULTADOS E DISCUSSÃO.

4.1 Pluviosidade e extrato do balanço hídrico durante o desenvolvimento da cultura.

4.2 Densidade do solo 27

4.3 Umidade do solo. 30

4.4 Desenvolvimento da parte aérea da planta.. 33

4.5 Desenvolvimento e distribuição do sistema radicular: método do monólito. 34

4.6 Análise comparativa dos métodos de amostragem de sistema radicular para massa seca de raízes.

4.7 Massa seca de raízes metabolicamente ativas quantificadas pelo método do monólito e pela diluição isotópica.. 42

4.8 Resíduos de raízes vivas no solo. 46

4.9 Análise comparativa dos métodos de amostragem do sistema radicular para massa seca de raízes metabolicamente ativas. 48

4.10 Considerações finais 51

5 CONCLUSÕES. 53

ANEXOS. 54

REFERÊNCIAS BIBLIOGRÁFICAS. 59 


\section{LISTA DE FIGURAS}

Página

1 Esquema de posicionamento dos blocos em campo

2 Proteção da superfície do solo com lona plástica (A) e aplicação de solução de uréia- ${ }^{15} \mathrm{~N}$ com pulverizador tipo “spray” (B)

3 Equipamentos utilizados para a coleta de amostras em campo: peça em aço inox para a amostragem dos monólitos (A) e sonda amostradora de raízes (B)

4 Esquema de colheita das amostras em campo.

5 Pluviometria durante o desenvolvimento da cultura, sendo que as barras verdes representam os meses de amostragem em campo

6 Extrato do balanço hídrico durante o desenvolvimento da cultura, dado pela deficiência (DEF) e excesso (EXC) hídricos............................................................

7 Densidade $\left(\mathrm{g} \mathrm{dm}^{-3}\right.$ ) média do solo em diferentes profundidades na linha e entrelinha da cultura, em janeiro, março, maio e junho de 2004; as barras

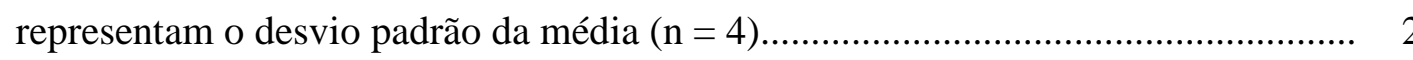


8 Densidade $\left(\mathrm{g} \mathrm{dm}^{-3}\right.$ ) média do solo, na linha e na entrelinha da cultura, nas profundidades de 0-20, 20-40, 40-60 e 60-80 cm, em função das épocas de amostragem; as barras representam o desvio padrão da média $(n=4)$.

9 Umidade $(\%, \mathrm{~m} / \mathrm{m})$ média do solo e sua distribuição no perfil, na linha e entrelinha da cultura, em janeiro, março, maio e junho de 2004; as barras representam o desvio padrão da média $(n=4)$.

10 Variação da Umidade $(\%, \mathrm{~m} / \mathrm{m})$ média do solo, na linha e na entrelinha da cultura, nas profundidades de 0-20, 20-40, 40-60 e 60-80 cm, em função das épocas de amostragem; as barras representam o desvio padrão da média $(n=4) \ldots \ldots$.

11 Massa seca e natural da parte aérea (colmos + ponteiros), em $\mathrm{t} \mathrm{ha}^{-1}$, nas quatro épocas de amostragem; letras diferentes representam diferença significativa a 5\% de probabilidade pelo teste $\mathrm{t}$

12 Massa seca do sistema radicular (raízes + rizomas), em $\mathrm{t} \mathrm{ha}{ }^{-1}$, nas quatro épocas de amostragem; letras diferentes representam diferença significativa a 5\% de probabilidade pelo teste $\mathrm{t}$.

13 Porcentagem de raízes no perfil do solo em profundidade (A) e em diferentes distâncias da linha de plantio (B), nas quatro épocas de amostragem.

14 Distribuição de raízes $\left(\mathrm{g} \mathrm{dm}^{-3}\right)$ no perfil do solo em janeiro, março, maio e junho de 2004; as barras representam o desvio padrão da média ( $\mathrm{n}=4)$.

15 Massa seca de raízes $\left(\mathrm{g} \mathrm{dm}^{-3}\right)$ pelos dois métodos de amostragem: monólito e sonda, para avaliação da distribuição de raízes no perfil do solo, na média das quatro épocas de amostragem; as barras representam o desvio padrão da média (n $=4)$. 
16 Massa seca de raízes $\left(\mathrm{g} \mathrm{dm}^{-3}\right)$ obtidas pelos métodos de amostragem: monólito e sonda, no perfil do solo, em janeiro, março, maio e junho de 2004; as barras representam o desvio padrão da média $(n=4)$

17 Raízes totais e raízes vivas ( $\mathrm{g} \mathrm{dm}^{-3}$ ) quantificadas pelo método do monólito, no perfil do solo, em janeiro, março, maio e junho de 2004; as barras representam o desvio padrão da média $(n=4)$.

18 Distribuição de raízes totais e raízes vivas quantificadas pelo método do monólito, no perfil do solo, em janeiro, março, maio e junho de 2004.

19 Distribuição de raízes totais e raízes vivas quantificadas pelo método do monólito, no perfil do solo, em janeiro, março, maio e junho de 2004.

20 Massa seca $\left(\mathrm{g} \mathrm{dm}^{-3}\right)$ de raízes vivas do monólito (RVM) e resíduo de raízes vivas no solo (resíduo RVsolo) em diferentes profundidades no perfil, em janeiro, março, maio e junho de 2004 .

21 Massa seca de raízes vivas $\left(\mathrm{g} \mathrm{dm}^{-3}\right.$ ) pelos dois métodos de amostragem: monólito (mais resíduo de raízes vivas no solo) e sonda, para avaliação da distribuição de raízes vivas no perfil do solo, na média das quatro épocas de amostragem; as barras representam o desvio padrão da média $(n=4)$.

22 Massa seca de raízes vivas $\left(\mathrm{g} \mathrm{dm}^{-3}\right.$ ) obtidas pelos métodos de amostragem: monólito (mais resíduos de raízes vivas no solo) e sonda, no perfil do solo, em janeiro, março, maio e junho de 2004; as barras representam o desvio padrão da média $(n=4)$. 


\section{LISTA DE QUADROS}

Página

1 Características agroindustriais da variedade RB85 5156 


\section{LISTA DE TABELAS}

Página

1 Caracterização química do solo.

2 Caracterização física do solo (composição granulométrica)

3 Testes de aplicações com pulverizador (“spray”).

4. Massa seca de raízes $\left(\mathrm{g} \mathrm{dm}^{-3}\right)$ de todo perfil do solo, de entrelinha a entrelinha, amostradas pelos métodos do monólito e da sonda, em quatro épocas de amostragens $(n=16)$.

5 Massa seca de raízes vivas $\left(\mathrm{g} \mathrm{dm}^{-3}\right)$ de todo perfil do solo, de entrelinha a entrelinha, amostradas pelos métodos do monólito e da sonda, em quatro épocas de amostragens $(n=16)$.

6 Abundância em ${ }^{15} \mathrm{~N}$ dos compartimentos estudados, nos diferentes locais e épocas de amostragem.

7 Teores de $\mathrm{N}$ (\%) dos compartimentos estudados, nos diferentes locais e épocas de amostragem.

8 Massa seca de raízes totais $\left(\mathrm{g} \mathrm{dm}^{-3}\right.$ ) pelos dois métodos de amostragem (monólito e sonda) e por local, para as quatro épocas de amostragem 
9 Massa seca de raízes vivas $\left(\mathrm{g} \mathrm{dm}^{-3}\right.$ ) pelos dois métodos de amostragem (monólito e sonda) e por local, para as quatro épocas de amostragem...................... 58 


\title{
SISTEMA RADICULAR DE CANA-DE-AÇÚCAR E IDENTIFICAÇÃO DE RAÍZES METABOLICAMENTE ATIVAS
}

\author{
Autor: CARLOS EDUARDO FARONI
}

Orientador: Prof. Dr. PAULO CESAR OCHEUZE TRIVELIN

\section{RESUMO}

O conhecimento da dinâmica de crescimento das raízes da cana-de-açúcar, bem como da arquitetura de seu sistema radicular, permite melhor compreensão das relações entre a planta e o seu ambiente de produção, possibilitando o manejo a partir de práticas agrícolas mais eficientes e sustentáveis que resultem em aumento de produtividade e longevidade da cultura. O presente estudo teve por objetivo desenvolver um método para determinação da distribuição e do desenvolvimento de raízes metabolicamente ativas de cana-de-açúcar no solo, por meio da técnica da diluição do isótopo ${ }^{15} \mathrm{~N}$, associado aos métodos de amostragem com monólito e sonda amostradora de raízes. O experimento foi realizado em área comercial de cana-de-açúcar na região canavieira de Piracicaba, Estado de São Paulo, em LATOSSOLO VERMELHO distrófico arenoso, com uma segunda rebrota do cultivar RB85 5156. O delineamento experimental foi em blocos subdivididos no tempo, com as amostragens de raízes realizadas a cada 50 a 60 dias de janeiro a junho de 2004. A uréia foi o veículo de fornecimento do marcador isotópico ${ }^{15} \mathrm{~N}$, por meio de solução aplicada às folhas das plantas. Após colheita da parte aérea, realizada 96 horas após a aplicação da solução de uréia, foram abertas trincheiras, transversalmente à linha da cultura, com dimensões de $1 \mathrm{~m}$ de comprimento e 1,4 m de largura. Amostras foram colhidas por meio de monólito nas profundidades de 0 a 20, 20 
a 40, 40 a 60 e 60 a 80 cm, na projeção da linha da cultura e lateralmente nas distâncias de 14 a $42 \mathrm{~cm}$ e de 42 a $70 \mathrm{~cm}$ da linha da cultura. Outras amostras foram colhidas com sonda amostradora de raízes, paralelamente à parede interna das trincheiras, a $10 \mathrm{~cm}$ de distância do local onde foram retirados os monólitos, nas mesmas profundidades e nas distâncias de 28 e 56 cm da linha. Em cada profundidade de amostragem, e na projeção da linha da cultura, foram separadas amostras de raízes visualmente ativas. Estas amostras forma consideradas padrão para a determinação por diluição isotópica de raízes com metabolismo ativo. As determinações do teor de $\mathrm{N}$ e de abundância de ${ }^{15} \mathrm{~N}$ em amostras de planta e de solo foram realizadas em um espectrômetro de massas modelo ANCA-SL da Eurapa Scientific Ltda. Os resultados mostraram que o método da diluição isotópica com ${ }^{15} \mathrm{~N}$ possibilitou avaliar a massa de raízes com metabolismo ativo e sua distribuição no solo, e o método de amostragem de raízes com a sonda foi viável em comparação com a amostragem do monólito, nas seguintes condições: na quantificação de raízes nas profundidades de 0 a 20, 20 a 40 e 60 a $80 \mathrm{~cm}$ do perfil do solo para raízes totais, e nos $20 \mathrm{~cm}$ superficiais do solo, profundidade na qual a massa de raízes foi maior, para raízes metabolicamente ativas. 


\title{
SUGAR CANE ROOT SYSTEM AND IDENTIFICATION OF ROOTS WITH ACTIVE METABOLISM
}

\author{
Author: CARLOS EDUARDO FARONI
}

Adviser: Prof. Dr. PAULO CESAR OCHEUZE TRIVELIN

\section{SUMMARY}

Knowledge about of sugarcane root growth dynamic, as well as the root system architecture of sugarcane crop allows understanding better the relationships between the plant and its environment. This knowledge is important to define the crop management with most efficiency and using sustainable practices, to increasing both sugarcane crop yield and longevity. The aim of this study was to evaluate a method in order to determine sugarcane roots with active metabolism and its distribution and growth in the soil profile, by using isotopic dilution technique with ${ }^{15} \mathrm{~N}$ associated with sampling by monolite and probe. The experiment was conducted in the sugarcane field, on the region of Piracicaba, State of São Paulo, Brazil, by using the second rattoon of the variety RB 85 5156, grown in a Rhodic Hapludox. The experimental design was in randomized blocks, with four replications. The split plot was considered in relation to the time. The

${ }^{15} \mathrm{~N}$ tracer was applied in the plants as urea solution. The above ground part of sugarcane plants were harvested 96 hours after urea solution applications, and trenches with one meter of length and 1.4 meter width were opened transversely to sugarcane rows. Samples were taken by monolite in 0-20, 20-40, 40-60 and 60-80 cm of depth in the soil profile in the row projection and horizontally in the distances of 14 to 42 and 42 to $70 \mathrm{~cm}$ from the cane row. Samples were taken by probe in a parallel plan with the 
internal trench wall at $10 \mathrm{~cm}$ of distance from the spot where monolites were collected, in the same depths and at 28 and $56 \mathrm{~cm}$ from the row. Roots visually assumed as metabolisms active were separated to each sampling depth and to row lateral projection and were considered standards to determine active roots. Determinations of $\mathrm{N}$ contents and ${ }^{15} \mathrm{~N}$ abundance in both plant and soil were carried on a mass spectrometer model ANCA-SL (Europa Scientific Ltda.). The results showed the isotopic dilution method with ${ }^{15} \mathrm{~N}$ allowed the evaluation of active roots mass and the root distribution in the soil. The root sampling method with probe was adequate comparing with root sampling by monolite in trench to quantify roots, in the following conditions: in the soil depths of 0 to 20,20 to 40 and 60 to $80 \mathrm{~cm}$ to total roots; and in the first $20 \mathrm{~cm}$ of depth, where the root mass was higher to active roots. 


\section{INTRODUÇÃO}

A agroindústria do açúcar e do álcool gera para o Brasil, em produto final, dez bilhões de dólares por ano, um milhão de empregos diretos e o seqüestro de $20 \%$ das emissões de carbono que o setor de combustíveis fósseis emite no país (Rodrigues, 2004). Com efeito, a cana-de-açúcar tem grande importância econômica, social e ambiental, fazendo do país o maior produtor mundial, com cinco milhões de hectares cultivados e uma produção que supera 340 milhões de toneladas de colmos. A região Centro-Sul concentra $85 \%$ da produção, das quais mais de $70 \%$ são produzidas no Estado de São Paulo (Unica, 2004).

A cana-de-açúcar é uma cultura que sob condições adequadas de suprimento de água possui elevada capacidade de conversão de energia luminosa em energia química (Câmara, 1993). No entanto, essa eficiência pode variar em função das condições edafoclimáticas e do estado nutricional da cultura. Um dos fatores de maior importância na relação planta-água-solo é a arquitetura e distribuição do sistema radicular, bem como sua dinâmica de crescimento (Vasconcelos, 2002a). Pelo exposto, o conhecimento do sistema radicular da cana-de-açúcar permite a utilização adequada das técnicas agronômicas, tais como: espaçamento, local de aplicação dos fertilizantes, operações de cultivo, drenagem dos solos e sistemas de irrigação, controle da erosão, uso de culturas intercalares, entre outras (Casagrande, 1991).

O estudo do sistema radicular, por ser muito trabalhoso, tem sido relegado a um plano secundário, apesar de sua importância. Os principais fatores para que isso ocorra são as grandes variabilidades de condições físicas, químicas e biológicas do solo, as quais influenciam na distribuição das raízes, podendo levar a resultados não representativos do desenvolvimento normal do sistema radicular das plantas 
(Vasconcelos et al., 2003). No estudo do desenvolvimento do sistema radicular da canade-açúcar há um agravante no que refere-se à renovação de raízes entre ciclos, ou no mesmo ciclo, tornando-se necessário a identificação de raízes vivas ou metabolicamente ativas em uma massa total amostrada.

Diante dessas dificuldades, o uso do método do traçador isotópico para nitrogênio $\left({ }^{15} \mathrm{~N}\right)$ possibilita quantificar as taxas de transferência do nutriente nos diferentes compartimentos do sistema, sendo empregado em estudos quando as técnicas clássicas são insuficientes, podendo o estudo do sistema radicular da cana-de-açúcar ser realizado com esse marcador isotópico por aplicação via foliar, já que o ${ }^{15} \mathrm{~N}$ é translocado às raízes (Trivelin et al., 1988a; Trivelin, 2000).

Nesse contexto, são formuladas as seguintes hipóteses: (1) o método da diluição isotópica com ${ }^{15} \mathrm{~N}$ possibilita avaliar a massa de raízes metabolicamente ativas e sua distribuição no solo e, (2) na quantificação e distribuição do sistema radicular da canade-açúcar no solo, o método de amostragem com uso de sonda amostradora de raízes é viável em comparação a amostragem com monólito em trincheira. Com base nestas hipóteses, o presente estudo tem por objetivo desenvolver um método para determinar e avaliar, com o uso da técnica da diluição isotópica com ${ }^{15} \mathrm{~N}$, a distribuição e o desenvolvimento de raízes metabolicamente ativas (vivas) de cana-de-açúcar no solo, associada às formas de amostragens: monólito e sondagem. 


\section{REVISÃO DE LITERATURA}

\subsection{Desenvolvimento e distribuição do sistema radicular da cana-de-açúcar}

As primeiras raízes que se desenvolvem após o plantio da cana-de-açúcar são as de fixação, originadas dos primórdios radiculares situados na zona radicular do tolete plantado (Bacchi, 1983; Castro \& Kluge, 2001). Durante aproximadamente 30 dias de brotação das gemas, a planta vive das reservas de nutrientes contidas no tolete e, parcialmente, do suprimento de água e nutrientes proporcionados por essas raízes de fixação (Bacchi, 1983; Blackburn, 1984). Após esse período inicia-se o desenvolvimento das raízes dos perfílhos primários, posteriormente dos secundários e assim sucessivamente. Na medida em que novas raízes vão se desenvolvendo, as de fixação vão perdendo sua função e a cana-planta passa a depender exclusivamente das raízes do perfílhos (Rochecouste, 1967). Dependendo das condições climáticas e do solo, em torno de 90 dias após o plantio todo o sistema radicular encontra-se distribuído nos primeiros $30 \mathrm{~cm}$ do solo (Casagrande, 1991).

Estudos citados por Dillewijn (1952) evidenciam a existência de três tipos básicos de raízes de cana-de-açúcar: raízes superficiais, ramificadas e absorventes; raízes de fixação, mais profundas; e raízes cordão, que podem atingir até seis metros de profundidade.

Após o corte da cana planta, o sistema radicular antigo mantem-se ainda em atividade por algum tempo, período em que é substituído pelas raízes dos novos perfilhos da soqueira, sendo esse processo lento e gradual. As raízes da soqueira são mais superficiais do que as da cana planta pelo fato dos perfilhos das soqueiras brotarem mais próximo da superfície do que os da cana planta. Pelo mesmo fato, quanto maior o 
número de cortes, mais superficial torna-se o sistema radicular das soqueiras (Bacchi, 1983).

Vários trabalhos foram desenvolvidos abordando a distribuição do sistema radicular de cana-de-açúcar no perfil do solo. Lee (1926), em trabalhos de distribuição do sistema radicular nas Ilhas Havaianas, verificou que a maioria das raízes da cultura encontrava-se nos $20 \mathrm{~cm}$ superficiais do solo, e que $85 \%$ encontravam-se até $60 \mathrm{~cm}$ de profundidade, sendo que a aeração do solo constituiu o principal fator para que as raízes da cana-de-açúcar tivessem boa superfície de absorção.

Jensen (1951), estudando o sistema radicular da cana-de-açúcar em Cuba, verificou que as variedades diferem pouco na distribuição de suas raízes e que todas emitem grande quantidade próximo à superfície do solo. Em todos os casos estudados, mais de 50\% das raízes da planta madura foram encontradas nos $20 \mathrm{~cm}$ superficiais do solo.

Em relação à distribuição do sistema radicular da cana-de-açúcar ao longo de seu ciclo, Inforzato \& Alvarez (1957) verificaram que 6 meses após o plantio o sistema radicular ultrapassava 2,10 m, estando bem distribuído em todas as camadas do solo, embora reduzisse, gradativamente, com a profundidade. Aos 6 meses foi encontrada 1,8 t ha ${ }^{-1}$ de raízes, a maioria até a profundidade de $70 \mathrm{~cm}$, representando $63 \%$ do total, sendo que nos primeiros $30 \mathrm{~cm}$ do solo encontravam-se $41 \%$ do sistema radicular. Aos 12 meses as plantas apresentaram grande aumento na massa de raízes em relação aos 6 meses, principalmente nas camadas superiores do solo, o que deveu-se, provavelmente, a maior umidade nesse período vegetativo da planta. Nos primeiros $30 \mathrm{~cm}$ do solo foram encontrados $71 \%$ das raízes, sendo que $61 \%$ situavam-se nos primeiros $20 \mathrm{~cm}$. O desenvolvimento do sistema radicular, com incremento na massa de raízes dos 6 aos 12 meses, mostrou estreita relação com o crescimento da parte aérea. Foram encontradas $8 \mathrm{t}$ ha $^{-1}$ de raízes aos 12 meses. Aos 18 meses o sistema radicular nos $30 \mathrm{~cm}$ superficiais correspondeu a $66 \%$ da massa radicular. Nesse estádio o sistema radicular foi menor em peso que aos 12 meses, sendo encontrada certa quantidade de raízes mortas, que não foi computada em virtude do estudo se restringir às raízes em atividade. 
Aguiar (1978) amostrou raízes aparentemente vivas e mortas, no Estado de São Paulo, durante um ciclo de cana-planta e observou que o máximo de formação das raízes aparentemente vivas deu-se de outubro a maio de 0-20 cm, de maio a outubro de 20-40 cm, e de maio a dezembro de 40-60 cm de profundidade. Essas constatações tinham como significado que as primeiras raízes a morrerem durante o período de estiagem foram as superficiais, as quais foram as primeiras a se renovarem durante o período de chuvas.

Em trabalho realizado por Korndörfer et al. (1989) também foi verificado que ao longo do perfil não ocorreram variações significativas na distribuição de raízes entre variedades. Na primeira amostragem a porcentagem de raízes na camada de 0 a $30 \mathrm{~cm}$ variou de 89 a 92\%, entre variedades. Numa segunda amostragem (cana soca) a porcentagem de raízes na camada de 0 a 40 cm variou de 85 a 92\%.

Alvarez (2000) estudando o crescimento de raízes de cana crua (colheita sem despalha a fogo) e queimada em dois ciclos, verificou que a quantidade de raízes foi maior no primeiro ano do que no segundo. Nos dois anos de amostragem as raízes concentraram-se mais na superfície do solo. No primeiro ano não houve diferença significativa entre a matéria seca de raízes $\left(\mathrm{g} \mathrm{m}^{-3}\right)$ de "cana crua" e queimada, em cinco profundidades avaliadas. No segundo ano, a matéria seca das raízes da cana queimada foi significativamente maior que as de "cana crua". A distribuição do sistema radicular mostrou que além das raízes se concentrarem na superfície, elas também têm presença marcante na proximidade do eixo da touceira.

Sampaio et al. (1987) identificaram, para as condições do nordeste brasileiro, que $75 \%$ da massa radicular da cana-de-açúcar estava localizada nos primeiros $20 \mathrm{~cm}$ superficiais e $50 \%$ estavam distantes a menos de $30 \mathrm{~cm}$ do centro da touceira. De forma geral, segundo Alvarez (2000), na cana crua há maior acúmulo de raízes em superfície e na cana queimada em profundidade, devido a maior umidade em solo coberto com palha, que não estimula o crescimento radicular até camadas mais profundas. O dessecamento da camada superficial do solo provoca uma readaptação do sistema radicular à procura de umidade em camadas mais profundas (Inforzato \& Alvarez, 1957). 
O desenvolvimento do sistema radicular é típico de cada variedade ou cultivar, havendo crescimento acumulativo do crescimento radicular durante os ciclos da cultura, da cana-planta para as socas sucessivas, sendo que a morte ou a renovação do sistema radicular não é causada pela colheita da cultura e sim pela deficiência hídrica, independente da fase de desenvolvimento (Aguiar, 1978; Vasconcelos, 2002b).

O sistema radicular (rizomas e raízes) é essencial para a rebrota das soqueiras após a colheita, já que ele cumpre o papel de reserva orgânica de energia e nutricional (Machado, 1987; Sampaio et al., 1987; Trivelin et al., 1988b e 2002; Camargo, 1989; Malavolta, 1994). Ao mesmo tempo em que ocorre a brotação das socas um novo sistema radicular é formado e algumas raízes vivas seriam importantes para alimentar os rebentos na fase inicial de desenvolvimento (Casagrande, 1991). Como mencionando anteriormente, a incorporação das raízes mortas ao solo, durante o período de crescimento, também pode contribuir para o aumento do seu teor de matéria orgânica (Ball-Coelho et al., 1992).

\subsection{Fatores que influenciam o desenvolvimento do sistema radicular}

Muitos fatores influenciam o desenvolvimento do sistema radicular, destacandose: riqueza do solo em elementos minerais, umidade e a aeração do solo (Inforzato \& Alvarez, 1957), acidez do solo e presença de alumínio e manganês tóxicos em subsuperfície (Raij, 1991; Havlin, 1999), além do sistema de manejo da cultura. Para haver máxima absorção de nutrientes pelas raízes são necessárias boas condições físicas, químicas e biológicas (avaliada, principalmente, pela ausência de pragas de solo). O suprimento ineficiente de oxigênio terá influência direta na absorção dos elementos essenciais N, P, K, S, Ca, Mg, Cl, B, Mn, Zn, Mo, Cu e Fe. A respiração aeróbia é o maior suprimento energético utilizado para a absorção de nutrientes e, para haver adequada aeração para sua sobrevivência, as raízes necessitam de $10 \%$ de volume de ar no solo (Kirkham, 1987).

Na cana-planta a maior quantidade de raízes favorece a produtividade em relação às soqueiras onde há manutenção de grande parte das raízes velhas e suberificadas que 
drenam as reservas que poderiam ser usadas para a produção de colmos e folhas. $\mathrm{O}$ desenvolvimento do sistema radicular é típico de cada variedade, tanto em quantidade, como em arquitetura, e em algumas variedades ele compete com a parte aérea por fotoassimilados, o que tem conseqüências desfavoráveis para a produtividade e acúmulo de sacarose. A distribuição no perfil do solo das raízes de uma variedade determina grande parte da sua adaptação ao ambiente, tanto em relação às condições climáticas, como ao tipo de solo (Vasconcelos et al., 2002a; Vasconcelos, 2002b).

De acordo com Korndörfer et al. (1989), quanto maior o sistema radicular de uma planta maior será a sua capacidade para explorar o solo e, conseqüentemente, a de aproveitar os nutrientes e a água disponível. O volume e a distribuição do sistema radicular são tão mais importantes quanto menor for a fertilidade do solo e maior a deficiência hídrica. O sistema radicular mais abundante aumenta os exsudados de raízes determinando maior atividade microbiana, o que tem influência no crescimento das plantas. De modo geral em solos profundos e sem impedimento físico, quanto maior o volume de raízes de uma variedade, maior sua capacidade para aproveitar a água disponível e os nutrientes (Korndörfer et al., 1989). Entretanto, em solos rasos ou com impedimento físico (compactação) ou químico (fertilidade), a eficiência em aproveitar água e os nutrientes parece ser mais importante do que o volume e a massa radicular.

\subsection{Avaliação do sistema radicular}

A avaliação do sistema radicular de uma cultura pode ser considerada fundamental no diagnóstico de sistemas de manejo que visam a otimização da produtividade agrícola, sendo que a distribuição das raízes no solo é resultante de uma série de processos complexos e dinâmicos, que incluem as interações entre o ambiente, o solo e as plantas em pleno crescimento (Fante Junior, 1999).

De acordo Köpke (1981), estudos sobre crescimento radicular devem ser feitos a partir da avaliação das características das raízes, como massa, comprimento e área, no tempo e no espaço, em conjunto com os fatores que influenciam a distribuição do sistema radicular, como densidade e porosidade do solo, água e ar disponíveis no solo, 
nutrientes e pH, dentre outros. Em estudos de raízes e suas interações com o solo (interface solo-raiz), a metodologia de quantificação é um fator limitante.

Segundo Bohm (1979) ${ }^{1}$, Schuurmann \& Goedewaagen $(1971)^{2}$ e Kopke (1981) ${ }^{3}$, citados por Fante Júnior (1999), existem vários métodos que permitem investigar a distribuição do sistema radicular, entretanto, avaliações do volume explorado, massa seca e comprimento radicular tratam-se de tarefas de difícil realização, com grandes limitações em todas as técnicas, como o tempo gasto, pouca informação obtida e elevada variabilidade dos resultados.

Vários são os métodos para estudo do sistema radicular de culturas em campo. Queiroz-Voltan et al. (1998) estudaram aspectos estruturais de raízes de cana-de-açúcar sob efeito da compactação do solo abriram trincheiras onde foram coletadas amostras de raízes em várias profundidades.

Fante Júnior et al. (1999), estudando o sistema radicular de aveia forrageira, utilizaram, entre outros métodos, a tradagem com o emprego de um trado manual de caneca de $5 \mathrm{~cm}$ de diâmetro e $10 \mathrm{~cm}$ de altura, sendo retiradas amostras da superfície até $50 \mathrm{~cm}$ de profundidade, ao longo de uma linha paralela à da cultura e distando em torno de $3 \mathrm{~cm}$ desta. Os autores deste trabalho concluíram que a distribuição do sistema radicular no solo apresentou considerável variabilidade espacial, mostrando maior relação com o tamanho das amostras que com o número delas.

Vasconcelos (2002b) realizou revisão sobre o tema, descrevendo métodos de avaliação do sistema radicular, tais como: extração de monólitos, tradagem e perfis de solo para filmagem e produção de imagens e/ou contagem do número de raízes.

\footnotetext{
${ }^{1}$ BOHM, W. Methods of studying root systems. New York: Springer-Verlag, 1979. 189p

${ }^{2}$ SCHUURMANN, J.J.; GOEDEWAAGEN, M.A.J. Methods for the examination of root systems and roots. 2.ed. Wageningen: Pudoc, 1971. 86p.

${ }^{3}$ KOPKE, U. Methods for studying root growth. In: SYMPOSIUM ON THE SOIL/ROOT SYSTEM IN RELATION TO BRAZILIAN AGRICULTURE, Londrina, 1980. Proceedings. Londrina: IAPAR, 1981. p.303-318.
} 


\subsection{Importância do nitrogênio para a cultura da cana-de-açúcar}

São muitos os trabalhos encontrados na literatura que mostram a importância do nitrogênio na cultura da cana-de-açúcar. O nutriente está em apenas 1\% da matéria seca total da planta, mas sua deficiência causa a redução na síntese de clorofila, de aminoácidos essenciais e da energia necessária à produção de carboidratos e esqueletos carbônicos (Dillewijn, 1952; Malavolta \& Haag, 1964; Alexander, 1973 e Epstein, 1975).

As maiores limitações do meio à produtividade da cana de açúcar, nas regiões canavieiras do Brasil, não se relacionam à radiação solar, à temperatura e, nem mesmo à água, mas sim à disponibilidade de quantidades adequadas de nutrientes minerais nos solos, com destaque ao nitrogênio (Trivelin, 2000).

O nitrogênio no ambiente é um elemento muito móvel e possui sete estados de valência ou níveis de oxidação que lhe permitem desempenhar seu complexo papel em processos vitais. A intensidade com que ocorrem as diferentes formas de ganhos e perdas do nutriente no agrossistema pode refletir a curto, médio e longo prazo na produção dos canaviais, uma vez que a cana-de-açúcar é considerada uma cultura semiperene. O perfeito entendimento da dinâmica do nitrogênio nesse sistema, determina possibilidades de manejo dessa cultura em condições variadas do meio, principalmente solo e clima, com o uso de cultivares melhorados que resultem em ganhos na produtividade agrícola e na sustentabilidade do agrossistema (Trivelin, 2000).

Entre os técnicos ligados ao setor agrícola de usinas produtoras de açúcar e álcool é voz corrente que se em determinado ano não for feita a adubação dos canaviais (soqueiras) com nitrogênio, a produtividade naquela safra não será afetada de forma marcante, mas o efeito ocorrerá nos anos seguintes, com reflexo na sua longevidade. Penatti et al. (1997) e Orlando Filho et al. (1999) constataram esse efeito e afirmaram que a resposta da cana-planta ao nitrogênio refletiu no maior vigor das soqueiras, aumentando a produção dos cortes subseqüentes, entre a cana-de-açúcar com e sem adubação nitrogenada. 
Em relação à distribuição do nitrogênio na planta, independentemente da dose de $\mathrm{N}$ aplicada ao solo, 28\% do nitrogênio acumulado na planta será encontrado na parte subterrânea: raízes e rizomas (Vitti, 1998; Trivelin et al., 2002). No trabalho realizado por Trivelin et al. (1988b), mais de 60\%do conteúdo de $\mathrm{N}$ na parte subterrânea, em média, foram localizados nos rizomas e, o restante, nas raízes. O teor de $\mathrm{N}$ na parte subterrânea foi 56\% superior ao da parte aérea, com a mesma ordem de grandeza em cana-planta. Ressalta-se ainda que o acúmulo de $\mathrm{N}$ na parte subterrânea da cana-deaçúcar está relacionado a rebrota da cultura que dependerá, nos primeiros estádios de desenvolvimento, dessa reserva nutricional.

O nitrogênio é importante também nos colmos sementes ou toletes de cana-deaçúcar usados no plantio. Mesmo se conhecendo pouco a respeito da utilização da reserva de nutrientes do tolete, é fato que quanto mais bem nutridos estes estiverem, melhor será a brotação e o desenvolvimento inicial da cana-planta. Na literatura, trabalhos demonstraram resposta à pré-fertilização com nitrogênio, alguns meses antes do corte de colmos destinados ao plantio, com menções sobre a influência do conteúdo de nitrogênio de colmos-semente na brotação da cana-de-açúcar (Humbert, 1968; Casagrande, 1991).

\subsection{Métodos de estudo do sistema radicular com traçador isotópico ${ }^{15} \mathrm{~N}$}

$\mathrm{O}$ uso do método do traçador isotópico para nitrogênio $\left({ }^{15} \mathrm{~N}\right)$ possibilita quantificar as taxas de transferência do nutriente nos diferentes compartimentos do sistema, podendo ser empregado em estudos quando as técnicas clássicas são insuficientes para o perfeito entendimento e quantificação de processos no ciclo do $\mathrm{N}$ (Trivelin, 2000). O estudo do sistema radicular da cana-de-açúcar pode ser realizado

com esse marcador isotópico via aplicação foliar, uma vez que o ${ }^{15} \mathrm{~N}$ é translocado até o sistema radicular (Trivelin et al., 1988a). 


\subsubsection{Métodos de fornecimento do marcador isotópico ${ }^{15} \mathrm{~N}$ às plantas}

Segundo Russel \& Fillery (1996) o marcador ${ }^{15} \mathrm{~N}$ pode ajudar a entender a contribuição dos restos culturais de leguminosas, especialmente raízes, às culturas subseqüentes em estudos de decomposição de resíduos dessas plantas no solo. Para isso é necessário que somente a planta seja marcada e não o solo. Os autores ainda comentam que poucos estudos sobre raízes têm sido desenvolvidos e que os procedimentos adotados na avaliação do $\mathrm{N}$ de sistema radicular raramente recuperam as raízes finas e as rizodeposições, sendo que uma fração substancial do $\mathrm{N}$ das leguminosas é derivado deste material. Sendo assim, os autores fizeram uma revisão de métodos ou técnicas de marcação do sistema radicular in situ, utilizadas não somente para leguminosas, mas também para gramíneas.

A aplicação foliar com ${ }^{15} \mathrm{~N}$-uréia é um dos métodos de marcação mais utilizados, mas a distribuição do traçador nas diferentes partes da planta é pouco uniforme. Trata-se de método pouco satisfatório em estudos de transferência de N no sistema, por não poder ser alcançado um balanço total do nutriente aplicado. Algumas das características do uso deste método são as perdas de $\mathrm{NH}_{3}$ após hidrólise da uréia no tecido foliar, e a remoção da ${ }^{15} \mathrm{~N}$-uréia das folhas por ação da chuva ou do orvalho, a qual é levada ao solo, invalidando a estimativa da quantidade de ${ }^{15} \mathrm{~N}$ no sistema radicular via translocação. Apesar destes pontos desfavoráveis, trata-se de uma técnica de fácil execução.

A imersão de folhas ou raízes em solução com ${ }^{15} \mathrm{~N}$ é uma técnica que supera muito dos problemas inerentes às aplicações foliares. O sistema confinado propicia uma grande absorção de ${ }^{15} \mathrm{~N}$ pela eliminação das perdas externas. O corte da folha, previamente a imersão em solução, aumenta a absorção e é necessário, também, o corte ou fendilhamento da raiz (objeto de estudo) para imersão na solução com ${ }^{15} \mathrm{~N}$.

Outra técnica que pode ser usada é a injeção de uma solução contendo ${ }^{15} \mathrm{~N}$, com a ressalva que para ser bem sucedida é necessário que seja feita em plantas maduras, por causa da dependência de um maior diâmetro de caule que suporte a quantidade e a concentração da solução a ser aplicada. 
O gás amônia enriquecido com ${ }^{15} \mathrm{~N}$ é uma forma muito eficiente de marcação de vegetais, sendo de rápida absorção e translocação devido ao seu fácil metabolismo. Além disso, o enriquecimento em ${ }^{15} \mathrm{~N}$ é uniforme na parte aérea e nas raízes das plantas. Suas limitações residem no custo das câmaras e equipamentos necessários para a obtenção de atmosfera controlada, na quantidade limitada de ${ }^{15} \mathrm{~N}$ que pode ser fornecida à planta, pois o gás de amônia é tóxico em altas concentrações, e no curto tempo de exposição.

O método utilizado por Russel \& Fillery (1996) foi o do 'cotton wick', ou método do fio de algodão. A metodologia consiste em transpassar um fio de algodão pelo caule da planta e mergulhar a extremidade desse fio em uma solução contendo o

${ }^{15} \mathrm{~N}$, a qual é absorvida por capilaridade realizando a marcação da planta por meio do sistema vascular. Essa técnica é tão eficiente quanto as outras, pois a absorção de $\mathrm{N}$ é função somente da transpiração da planta, diferente da absorção foliar ou radicular que ocorre por mecanismos ativos e passivos.

\subsubsection{Fornecimento via foliar, absorção e distribuição da uréia ${ }^{15} \mathrm{~N}$ na planta}

O fornecimento foliar de fontes nitrogenadas marcadas com ${ }^{15} \mathrm{~N}$, em princípio, não causa distúrbios à planta, na qual o material marcado distribui-se uniformemente podendo ser utilizado para determinar o $\mathrm{N}$ no sistema radicular (Jansen \& Bruinsma, 1989). A aplicação de solução diluída com uréia marcada em ${ }^{15} \mathrm{~N}$, por meio de pulverização foliar, tem sido usada com sucesso na marcação de leguminosas (Zebarth et al., 1991; Ambrosano et al., 2003).

McNeill et al. (1997) estudando o nitrogênio no sistema solo-planta em espécies de pastagem na Austrália, trevo (Trifolium subterraneum L.) e serradella (Ornithopus compressus L.), consideraram adequado o método de fornecimento de ${ }^{15} \mathrm{~N}$ via aplicação foliar com uréia marcada, o qual mesmo em soluções de baixas concentrações foi suficiente para marcar as raízes das plantas e traçar a dinâmica do elemento no sistema. A recuperação do ${ }^{15} \mathrm{~N}$ aplicado às plantas citadas variou de 74 a $84 \%$ no período 
vegetativo, sendo que a recuperação do elemento marcado no sistema radicular variou de 7 a $26 \%$.

A uréia apresenta-se como fonte de nitrogênio adequada para fornecimento via foliar, pois sua solubilidade em água e alto conteúdo de nitrogênio permitem aplicações de boa quantidade do nutriente quer seja aplicado em solução, quer na forma sólida (Thorne, 1955). A uréia aplicada às folhas dos vegetais é absorvida tão rapidamente como qualquer outra forma nitrogenada, constituindo fator positivo para seu uso em adubação foliar (Wittwer \& Teubner, 1959).

O tempo requerido para absorção de $50 \%$ do nitrogênio da uréia pulverizada na folha de cana-de-açúcar é inferior a 24 horas (Wittwer \& Teubner, 1959; Malavolta, 1994). Segundo Humbert (1960) estimativas obtidas por meio de observações microscópicas da presença de cristais de uréia sobre as folhas de cana-de-açúcar indicaram que 75 a 85\% do $\mathrm{N}$ das pulverizações foram absorvidos entre 24 e 48 horas. Em adição, Takahashi (1959) quantificou que 45, 74 e $79 \%$ de 0,2 g de uréia- ${ }^{15} \mathrm{~N}$ aplicada em solução às bainhas de folhas de cana-de-açúcar foram absorvidos após 24 , 72 e 168 horas, respectivamente. Trivelin et al. (1985) concluíram que foram absorvidos cerca de 50\% de $\mathrm{N}$-uréia, equivalente a aproximadamente $6 \mathrm{~kg} \mathrm{ha}^{-1}$ de $\mathrm{N}$-uréia, no intervalo de uma hora após a aplicação foliar, não se constatando absorção além desse valor até 7 horas. Os resultados de abundância de ${ }^{15} \mathrm{~N}$ desses estudos, comparadas às dos controles, indicaram ter havido absorção do N-uréia, ficando também evidenciada a translocação do nutriente ao sistema radicular no ciclo de cana-planta, assim como a remobilização desse nitrogênio do sistema radicular para a parte aérea na primeira rebrota (Trivelin et al., 1984). Os resultados de abundância de ${ }^{15} \mathrm{~N}$ nas raízes informaram que a absorção foliar ocorreu, evidenciando a translocação do N-uréia 6 horas após a aplicação foliar. O aumento na abundância de ${ }^{15} \mathrm{~N}$ nas raízes com o tempo indicou que a translocação do $\mathrm{N}$ da uréia teve continuidade no período experimental (Trivelin et al., 1988a).

A soma dos valores de NPPF (Nitrogênio da Planta Proveniente do Fertilizante) da parte aérea (24,4 mg de N-uréia) e do sistema radicular (21,3 mg de N-uréia), no ciclo da primeira rebrota, representou o $\mathrm{N}$-uréia aplicado às folhas que foi absorvido e 
translocado ao sistema radicular, antes do primeiro corte (7\% do N-uréia aplicado), e que redistribuiu-se em partes iguais no ciclo da primeira rebrota (Trivelin et al., 1984). Esses resultados evidenciaram o papel do $\mathrm{N}$ armazenado nas raízes e rizomas da canade-açúcar na rebrota da cultura.

Conforme Trivelin et al. (1988a), o nitrogênio aplicado às folhas e translocado às raízes indicaram efeito estatístico para o fator tempo, evidenciando que a translocação de $\mathrm{N}$ foi contínua até 96 horas após a fertilização foliar. O máximo valor obtido (5,5\% do N-uréia absorvido) mostrou-se inferior a trabalhos anteriores como Trivelin et al. (1984 e 1985). Deve-se considerar que naqueles a primeira amostragem das plantas ocorreu após 7 dias da adubação foliar e foram usadas touceiras de cana-de-açúcar em estádios mais avançados de desenvolvimento e, possivelmente, foram maiores as velocidades de translocação do $\mathrm{N}$ para sustentar o crescimento radicular, ou como mecanismo de armazenamento do nutriente para suprir as necessidades de uma futura rebrota. A translocação do nitrogênio ocorreu continuamente da parte aérea ao sistema radicular durante cinco dias após a fertilização foliar, sendo encontrado nas raízes, aproximadamente, $5 \%$ do N-uréia absorvido. O teor de N no sistema radicular foi $50 \%$ maior que o da parte aérea (folhas secas + colmos + ponteiros). Isso colocou novamente em evidência que o acúmulo do nutriente em raízes e rizomas trata-se de mecanismo de reserva da planta, a fim de sustentar a rebrota do ciclo subseqüente (Trivelin et al., 1988b; Camargo, 1989; Malavolta, 1994).

Pelo exposto, fica destacada a importância do conhecimento da distribuição no solo, desenvolvimento e acúmulo de $\mathrm{N}$ no sistema radicular da cana-de-açúcar, parte viva e não viva, em diferentes estádios e possíveis relações com a produtividade da cultura. 


\section{MATERIAL E MÉTODOS}

\subsection{Localização da área experimental, variedade de cana-de-açúcar, tipo de solo, manejo e épocas de amostragem}

A área experimental localizou-se em talhão comercial (6 ha) de cana-de-açúcar, na Fazenda São Luiz, pertencente ao Grupo COSAN S/A - Unidade Costa Pinto, no Município de Piracicaba, SP.

O ambiente de produção da área experimental é classificado como “D” (Landell et al., 2004), portanto de médio potencial de produção, com produtividade esperada de 80 a 84 t ha ${ }^{-1}$ em colmos. A variedade de cana-de-açúcar utilizada foi a RB85 5156, de alta precocidade em maturação e boa soqueira, sendo suas características agroindustriais descritas no Quadro 1.

\begin{tabular}{|cl|}
\hline \multicolumn{2}{|c|}{ Características Agroindustriais } \\
\hline Produtividade & Florescimento .............. intenso \\
Cana-planta ................... média & Chochamento ............... pouco \\
Cana-soca ...................... média & Teor de sacarose ........... alto \\
Exigência em solos ............. média & Precocidade ................... elevada \\
Brotação de soqueira ........... boa & Teor de fibra ................. baixo \\
Perfilhamento ..................... bom & Sensibil. a herbicidas...... não \\
Fechamento entrelinhas ........ bom & Declínio de outono .......... sim \\
Tombamento ..................... bastante & \\
\hline
\end{tabular}

Fonte: http://pmgca.dbv.cca.ufscar.br/htm/catal/rb855156.php

Quadro 1 - Características agroindustriais da variedade RB85 5156 
O solo da área experimental foi classificado como Latossolo Vermelho distrófico (Embrapa, 1999), de textura arenosa em superfície e média em subsuperfície, porém sem gradiente textural entre os horizontes. Suas características químicas e físicas são demonstradas nas Tabelas 1 e 2 respectivamente.

A acidez do solo foi corrigida com a aplicação de 3,0 $\mathrm{t} \mathrm{ha}^{-1}$ de calcário, previamente ao plantio, que foi realizado em 13 de setembro de 2001, como cana de ano (inverno), com espaçamento de 1,4 m entre linhas. A adubação mineral de plantio consistiu na aplicação $25 \mathrm{~kg} \mathrm{ha}^{-1}$ de N, $55 \mathrm{~kg} \mathrm{ha}^{-1}$ de P e $105 \mathrm{~kg} \mathrm{ha}^{-1}$ de K. Foi realizada, também, adubação orgânica com a aplicação de $25 \mathrm{t} \mathrm{ha}^{-1}$ de torta de filtro no sulco de plantio.

A primeira colheita foi realizada manualmente em 2 de maio de 2002, com produtividade média de $86 \mathrm{t} \mathrm{ha}^{-1}$ em colmos. Sucedeu-se ao corte o cultivo com operação de escarificação e a adubação da área com $100 \mathrm{~kg} \mathrm{ha}^{-1}$ de N e $125 \mathrm{~kg} \mathrm{ha}^{-1}$ de K. A segunda colheita, também manual, foi realizada no dia 7 de maio de 2003, com produtividade média de $80 \mathrm{t} \mathrm{ha}^{-1}$ em colmos. Após esse corte foi aplicado, em cobertura, 3,0 t ha ${ }^{-1}$ de calcário e 2,1 t ha ${ }^{-1}$ de gesso agrícola. A área foi novamente cultivada e adubada com $100 \mathrm{~kg} \mathrm{ha}^{-1}$ de $\mathrm{N}$ e $125 \mathrm{~kg} \mathrm{ha}^{-1}$ de $\mathrm{K}$. As amostragens de raízes foram realizadas em 19 de janeiro, 10 de março, 11 de maio e 22 de junho de 2004.

Tabela 1. Caracterização química do solo

\begin{tabular}{ccccccccccccc}
\hline prof & $\mathrm{pH}$ & M.O. & P res. & $\mathrm{K}$ & $\mathrm{Ca}$ & $\mathrm{Mg}$ & $\mathrm{H}+\mathrm{Al}$ & $\mathrm{Al}$ & $\mathrm{SB}$ & $\mathrm{CTC}$ & $\mathrm{V}$ & $\mathrm{m}$ \\
\hline $\mathrm{cm}$ & $\mathrm{CaCl}_{2}$ & $\mathrm{~g} \mathrm{dm}^{-3}$ & $\mathrm{mg} \mathrm{dm}^{-3}$ & & \multicolumn{5}{c}{$\mathrm{mmol}_{\mathrm{c}} \mathrm{dm}^{-3}$} \\
$0-20$ & 5,2 & 9 & 8 & 0,8 & 24 & 6 & 16 & 1 & 31 & 47 & 66 & 3 \\
$20-40$ & 4,8 & 7 & 5 & 0,5 & 17 & 5 & 18 & 3 & 23 & 41 & 56 & 12 \\
$40-60$ & 4,4 & 6 & 3 & 0,1 & 16 & 5 & 31 & 9 & 21 & 52 & 41 & 30 \\
$60-80$ & 4,1 & 4 & 2 & 0,1 & 10 & 3 & 34 & 13 & 13 & 47 & 28 & 50 \\
\hline
\end{tabular}

Tabela 2. Caracterização física do solo (composição granulométrica)

\begin{tabular}{cccccc}
\hline prof & argila & silte & areia total & areia grossa & areia fina \\
\hline $\mathrm{cm}$ & & & $\mathrm{g} \mathrm{kg}^{-1}$ & & \\
$0-20$ & 124 & 4 & 872 & 220 & 652 \\
$60-80$ & 180 & 10 & 810 & 230 & 580 \\
\hline
\end{tabular}




\subsection{Delineamento e parcelas experimentais}

O delineamento experimental utilizado foi o de blocos subdivididos no tempo, com parcelas e subparcelas, com quatro repetições (blocos por época) e quatro épocas de amostragem. Os blocos foram distribuídos transversalmente ao sentido da linha de plantio (controle local), sendo cada bloco correspondente a uma trincheira.

As parcelas, dentro de cada bloco, representavam os locais de amostragem, formados pela intersecção de uma profundidade $(0-20,20-40,40-60$ ou $60-80 \mathrm{~cm})$ e de uma distância da linha de plantio (na linha, 14-42 ou 42-70 cm da linha), totalizando 12 parcelas por bloco. As subparcelas, dentro de cada parcela, representavam os métodos de amostragem (monólito ou sonda), totalizando 24 subparcelas por bloco.

Os blocos constituíram-se de três segmentos contíguos de linhas de cana-deaçúcar de dois metros de comprimento, posicionados distantes três linhas um do outro, como esquematizado na Figura 1.

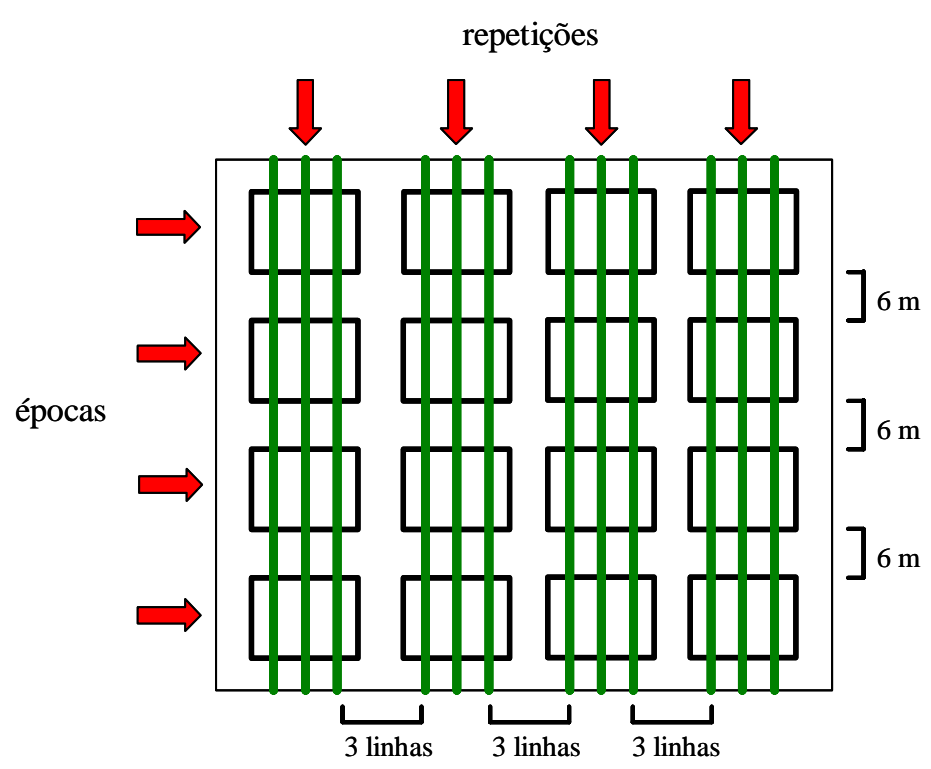

Faz. São Luiz

Figura 1 - Esquema de posicionamento dos blocos em campo 


\subsection{Solução de uréia- $-{ }^{15} \mathrm{~N}$ e forma de aplicação}

A fonte utilizada como marcador isotópico ${ }^{15} \mathrm{~N}$ foi a uréia com abundância de $25 \%$ em átomos de ${ }^{15} \mathrm{~N}$, fornecida em $10 \mathrm{~mL}$ de solução na concentração de $31 \%$ (m/v), às plantas do segmento central de $2 \mathrm{~m}$ de comprimento de cada bloco.

A aplicação da solução de uréia foi feita por pulverização foliar, sendo a colheita do material realizada após 96 horas da aplicação. Antes das pulverizações, o solo foi coberto com lona plástica (Figura 2A), dos dois lados do segmento de linha a ser pulverizado, a fim de evitar um possível contato da solução com o solo por deriva ou escorrimento. A lona plástica permaneceu recobrindo a superfície do solo até a colheita.

Para pulverização da solução foram usados aplicadores ou "sprays” (Figura 2B) para adição às folhas de pequenos volumes de solução, tentando-se evitar o escorrimento pelas folhas e colmos. Após o crescimento das plantas, procurou-se aplicar a solução o mais próximo à região das bainhas. Os "sprays” foram testados antes do uso, a fim de aferir a repetibilidade dos volumes aplicados, como demonstrado na Tabela 3. Foram utilizados os quatro "sprays” de menores coeficientes de variação para o volume total de solução aplicada. Como nem todo volume de solução (10 mL) era aplicado, procedia-se, após cada aplicação, adição de água ao reservatório $(5 \mathrm{~mL})$ para a aplicação da restante da solução do frasco, procurando-se com esse procedimento transferir toda solução de uréia às plantas.
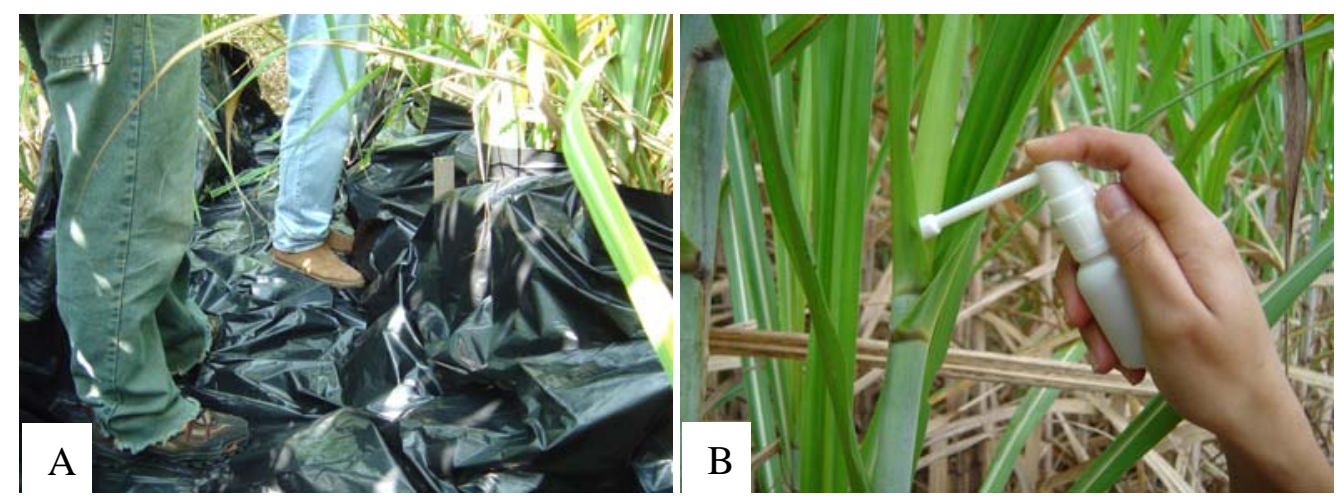

Figura 2 - Proteção da superfície do solo com lona plástica (A) e aplicação de solução de uréia- ${ }^{15} \mathrm{~N}$ com pulverizador tipo “spray” (B) 
Tabela 3. Testes de aplicações com pulverizador (“spray”)

\begin{tabular}{ccccc}
\hline "Spray" & Vol. Solução & Esborrifadas & Vol. Aplicado & Coef. Var. \\
\hline 01 & $\mathrm{~mL}$ & $\mathrm{n}^{\mathbf{0}}$ & $\mathrm{mL}$ & $\%$ \\
02 & 10 & 121 & 9,01 & 4,2 \\
03 & 10 & 124 & 8,63 & 2,3 \\
04 & 10 & 123 & 8,89 & 4,6 \\
05 & 10 & 140 & 7,67 & 13,6 \\
06 & 10 & 130 & 8,53 & 7,6 \\
\hline
\end{tabular}

\subsection{Equipamentos utilizados nas amostragens}

Na colheita das amostras de solo juntamente com raízes foram utilizados dois métodos: monólitos colhidos na parede de trincheiras e sondagens.

Para amostragem dos monólitos (Figura 3A) foi confeccionado um equipamento em aço inox com as dimensões de: $28 \mathrm{~cm}$ de comprimento, $10 \mathrm{~cm}$ de largura e $20 \mathrm{~cm}$ de profundidade, com volume de coleta de 5,6 $\mathrm{dm}^{3}$. Essas dimensões foram definidas em função do espaçamento da cultura e das profundidades de amostragem.

Para a sondagem foi utilizada a sonda amostradora de raízes (Figura 3B), fabricada em aço inox, com as seguintes dimensões: $120 \mathrm{~cm}$ de comprimento e 5,5 cm de diâmetro interno, com volume de coleta de aproximadamente $0,48 \mathrm{dm}^{3}$, a cada $20 \mathrm{~cm}$ de profundidade de sondagem.
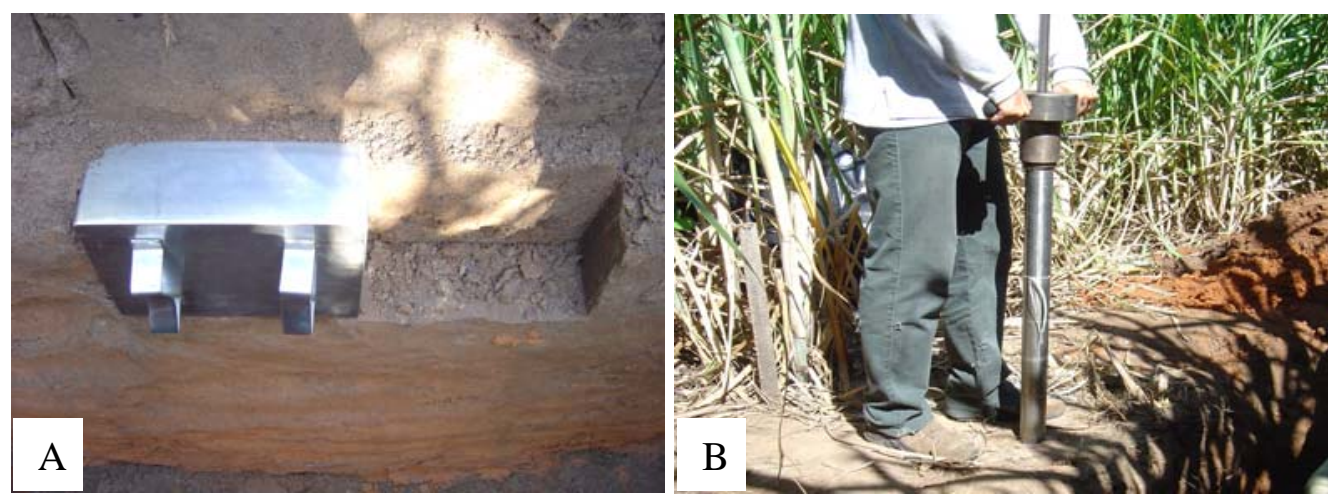

Figura 3 - Equipamentos utilizados para a coleta de amostras em campo: peça em aço inox para a amostragem dos monólitos (A) e sonda amostradora de raízes (B) 


\subsection{Esquema de coleta de amostras de planta e de solo contendo raízes}

A amostragem da parte aérea da cultura foi feita colhendo-se as plantas no segmento de $2 \mathrm{~m}$ da linha central da parcela, que foi marcada com ${ }^{15} \mathrm{~N}$. As plantas das linhas paralelas e contíguas a esse seguimento também foram colhidas com o objetivo de estimar a produção da cultura, em cada época de amostragem. A amostragem da parte subterrânea foi realizada pelos dois métodos citados, conforme o esquema da Figura 4.

Os monólitos foram obtidos após a colheita da parte aérea, na parede de trincheiras abertas transversalmente à linha de cana, no centro das parcelas marcadas com ${ }^{15} \mathrm{~N}$, após a colheita da parte aérea. As trincheiras tinham dimensões de $1 \mathrm{~m}$ na linha e 1,4 m de entrelinha a entrelinha. As amostras com as dimensões do monólito - $28 \mathrm{~cm}$ de comprimento, $10 \mathrm{~cm}$ de espessura e $20 \mathrm{~cm}$ de profundidade - foram colhidas nas profundidades de 0-20, 20-40, 40-60 e 60-80 cm, na projeção da linha da cultura e nas laterais dessas amostras, distantes de 14 a 42 cm e de 42 a $70 \mathrm{~cm}$ da linha.

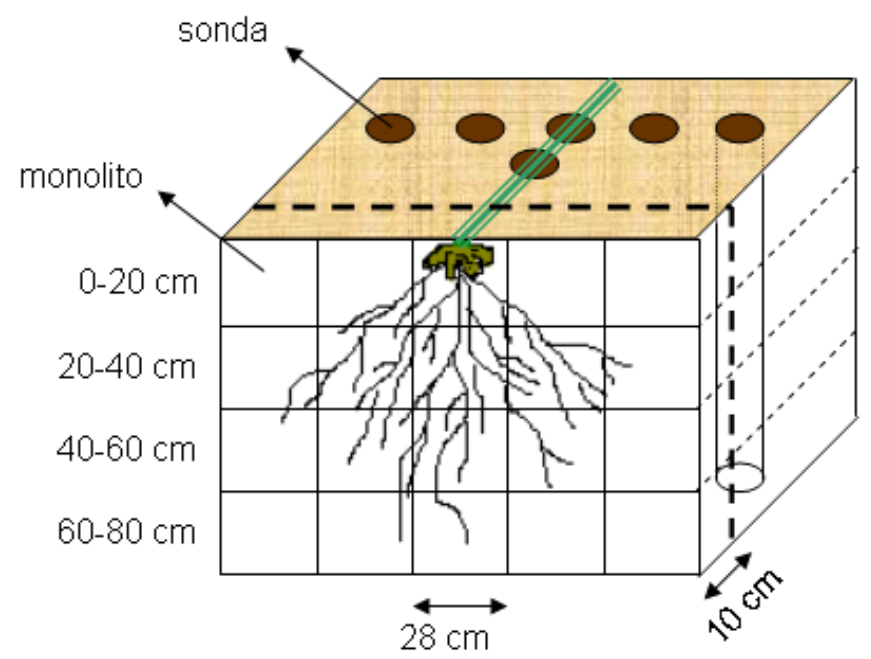

Figura 4 - Esquema de colheita das amostras em campo 
As sondagens foram feitas paralelamente à superfície da trincheira, distando de $10 \mathrm{~cm}$ do local onde foram coletados os monólitos. As amostras com a sonda foram coletadas nas profundidades de 0-20, 20-40, 40-60 e 60-80 cm, em dois pontos na projeção da linha da cultura e nas suas laterais, distantes de $28 \mathrm{~cm}$ e de $56 \mathrm{~cm}$ da linha. Foi também coletado, na linha e na entrelinha da cultura, nas profundidades de amostragem, solo em anéis volumétricos a fim de avaliar a densidade e a umidade do solo.

\subsection{Processamento do material colhido}

O preparo das amostras de planta e solo foi feito conforme Trivelin et al. (1984 e 1985). Em cada época de amostragem, a parte aérea da planta foi pesada logo após corte e triturada em uma desfibradora tipo forrageira. Foram feitas subamostragens do total do material processado, de cada bloco, e colocadas para secar em estufa com circulação forçada de ar a $65^{\circ} \mathrm{C}$ por $48 \mathrm{~h}$. Após a secagem do material foi determinada sua umidade e o material seco foi passado em moinho de facas, homogeneizado e levado para determinações de N-total e de abundância de ${ }^{15} \mathrm{~N}$.

Para as amostras de solo colhidas por sondagem e pelo método da trincheira (monólito) foram separadas as seguintes amostras: (1) solo + raízes (totais), (2) raízes totais e (3) raízes vivas. Após a coleta dos monólitos e das sondagens, as raízes foram separadas do solo por peneiramento (malha $2 \mathrm{~mm}$ ), obtendo-se amostras de raízes totais. Nas amostras de raízes (2 e 3), o solo aderido foi removido por meio de lavagem em água corrente. As amostras de raízes, tanto do monólito, quanto da sonda, foram secas em estufa com circulação forçada de ar a $65^{\circ} \mathrm{C}$ por $48 \mathrm{~h}$. Após a secagem, as amostras foram pesadas para quantificação de massa seca e estimativa da distribuição do sistema radicular no perfil do solo.

As amostras de raízes do monólito, depois de pesadas, foram moídas em moinho de facas e subamostradas para poderem ser analisadas. As amostras de raízes da sonda também foram moídas em moinho de facas, mas todo material processado foi homogeneizado com a amostra de solo de onde ela foi peneirada, para compor as 
amostras do tipo (1) solo + raízes. Tanto essas amostras, quanto as amostras de solo do monólito foram passadas em moinho de bola para uma melhor homogeneização antes das determinações de $\mathrm{N}$-total e de abundância de ${ }^{15} \mathrm{~N}$.

Desde a superfície, e por todo o perfil do solo onde foram coletados os monólitos, para cada profundidade de amostragem e na projeção da linha da cultura, foram separadas amostras de raízes consideradas visualmente vivas (ativas). Essas amostras foram consideradas padrões na determinação, por diluição isotópica, de raízes vivas do total de raízes. Para a utilização dessas raízes como padrões aceitou-se, segundo Jansen \& Bruinsma (1989), a suposição da uniformidade de distribuição do marcador isotópico na planta.

Os anéis volumétricos coletados foram pesados e secos em estufa a $105^{\circ} \mathrm{C}$ por 48h. Logo após a secagem foram tomadas as suas massas para as avaliações de densidade $\left(\mathrm{g} \mathrm{cm}^{-3}\right)$ e umidade $(\%, \mathrm{~m} / \mathrm{m})$ de solo, sendo que para os dados de densidade foram usados a massa de solo seco e o volume dos anéis.

\subsection{Determinações de N-total e de abundância de ${ }^{15} \mathrm{~N}$}

As determinações do teor de $\mathrm{N}$ e de abundância de ${ }^{15} \mathrm{~N}$ em amostras de planta e solo foram realizadas no CENA/USP, em espectrômetro de massas automatizado modelo ANCA-SL, da Europa Científica (Barrie \& Prosser, 1996).

\subsection{Cálculos para quantificação da massa seca de raízes metabolicamente ativas (vivas)}

Para o cálculo do material seco de raízes metabolicamente ativas de cada amostra foram utilizadas as abundâncias isotópicas, as massas e os teores de $\mathrm{N}$ destas amostras, além das abundâncias e dos teores de $\mathrm{N}$ dos padrões de raízes vivas e as abundâncias de solo natural (anexos A, B, C e D), segundo McNeill et al. (1997) e Trivelin et al. (2002). Doravante, neste trabalho as raízes metabolicamente ativas, quantificadas pela técnica da 
diluição isotópica com ${ }^{15} \mathrm{~N}$, serão também referidas como raízes vivas, apesar de nem todas as raízes vivas serem ativas quanto a distribuição do composto marcado.

A porcentagem de $\mathrm{N}$ em uma amostra derivada de raiz viva (\%NARV) é obtida pela equação:

$\%$ NARV $=\left[\left(\%{ }^{15} \mathrm{~N}_{\text {amostra }}-\%{ }^{15} \mathrm{~N}_{\text {solo }}\right) /\left(\%{ }^{15} \mathrm{~N}_{\text {raiz viva }}-\%{ }^{15} \mathrm{~N}_{\text {solo }}\right)\right] .10^{2}$

significando: \% ${ }^{15} \mathrm{~N}_{\text {amostra }}$ - abundância em átomos \% de ${ }^{15} \mathrm{~N}$ na amostra; $\%{ }^{15} \mathrm{~N}_{\text {solo }}$ abundância em átomos \% de ${ }^{15} \mathrm{~N}$ no solo natural sem aplicação do traçador; $\%{ }^{15} \mathrm{~N}_{\text {raiz viva }}$ abundância em átomos \% de ${ }^{15} \mathrm{~N}$ na raiz viva (padrão).

A quantidade de $\mathrm{N}$ total das amostras (NTA) é dada por:

$\mathrm{NTA}=\mathrm{M}_{\mathrm{amostra}} \cdot\left(\% \mathrm{~N}_{\text {amostra }} / 10^{2}\right)$

onde: $\mathrm{M}_{\mathrm{amostra}}$ é a massa da amostra; \% $\mathrm{N}_{\text {amostra }}$ é o teor de nitrogênio na amostra.

A quantidade de $\mathrm{N}$ da amostra proveniente de raízes vivas (QNARV) é obtida da conjugação das equações (1) e (2) e representada por:

QNARV $=\left(\%\right.$ NARV $\left./ 10^{2}\right)$. NTA

Com a QNARV pode-se calcular a massa seca de raízes vivas da amostra (MSRVA), em mg:

$\operatorname{MSRVA}=\left[(\mathrm{QNARV}) \cdot 10^{2}\right] / \% \mathrm{~N}_{\text {raiz viva }}$

Incluindo-se todas as variáveis utilizadas para o cálculo da MSRVA na equação (4), tem-se: 
MSRVA $=\left\{\left[\left(\%{ }^{15}\right.\right.\right.$ Nexc.amostra $) /\left(\%{ }^{15}\right.$ Nexc.raiz viva $\left.\left.)\right] . M_{\text {amostra }} \cdot \% \mathrm{~N}_{\text {amostra }}\right\} / \% \mathrm{~N}_{\text {raiz viva }}$

significando: $\%{ }^{15}$ Nexc.amostra - porcentagem de átomos de ${ }^{15} \mathrm{~N}$ em excesso na amostra; $\%{ }^{15} \mathrm{Nexc}$.raiz viva - porcentagem de átomos de ${ }^{15} \mathrm{~N}$ em excesso na raiz viva; $\% \mathrm{~N}_{\text {raiz viva }}$ teor de nitrogênio na raiz viva.

A equação (5) pode ser usada para amostras de solo, solo + raízes e raízes, desde que as massas das amostras sejam utilizadas em base seca.

\subsection{Pluviosidade e balanço hídrico simplificado durante o desenvolvimento da cana- de-açúcar}

Os dados de pluviometria e do extrato do balanço hídrico utilizados para caracterização do regime hídrico durante o período de desenvolvimento da cultura foram obtidos da estação metereológica automatizada do Departamento de Ciências Exatas ESALQ/USP. O extrato do balanço hídrico foi calculado segundo Camargo \& Camargo (1993), com o auxílio de planilha eletrônica fornecida pelo departamento citado.

\subsection{Análise estatística}

Os valores obtidos de massa seca de raízes totais e vivas foram submetidos a análise de variância, utilizando o teste F de Fisher e Snedecor, ao nível de 95\% de probabilidade, para cada local de amostragem. Os métodos de amostragem foram comparados no perfil do solo utilizando-se o erro padrão da média (n=4), e a comparação de médias para cada época foi feita com teste de Tukey, ao nível de 5\% de significância. Para a análise dos dados foi utilizado o programa SAS (SAS Institute, 1991). 


\section{RESULTADOS E DISCUSSÃO}

\subsection{Pluviosidade e extrato do balanço hídrico durante o desenvolvimento da cultura}

A pluviosidade e o extrato do balanço hídrico, referentes ao período de desenvolvimento da cana-de-açúcar (setembro de 2001 a junho de 2004) estão representados nas Figuras 5 e 6 respectivamente.

O plantio, na primeira quinzena de setembro de 2001, foi realizado ao final do período de deficiência hídrica (Figura 6). Nos meses seguintes, com o aumento da pluviosidade, principalmente entre dezembro de 2001 e março de 2002, a cultura passou a se desenvolver com excedente hídrico até o primeiro corte (2/5/2002), não sendo a disponibilidade de água, nesse período, fator limitante ao desenvolvimento do sistema radicular.

O ciclo da primeira soca, no entanto, passou por um período com deficiência hídrica entre maio e outubro de 2002, com precipitação acumulada de 281mm de chuva e deficiência hídrica acumulada de $277 \mathrm{~mm}$. A partir de novembro de 2002, até o segundo corte (7/5/2003), a cultura passou por período com excedente hídrico nos meses de novembro de 2002 a janeiro de 2003, passando por um pequeno veranico em fevereiro de 2003, sendo que no mês do segundo corte iniciava um novo período de deficiência hídrica.

O ciclo da segunda soca, da mesma forma que o da primeira, caracterizou-se por um período inicial com deficiência hídrica, de maio a novembro de 2003, com precipitação acumulada de 198 mm e deficiência hídrica acumulada de 267 mm. Houve excedente hídrico com aumento da pluviosidade a partir de novembro de 2003. 


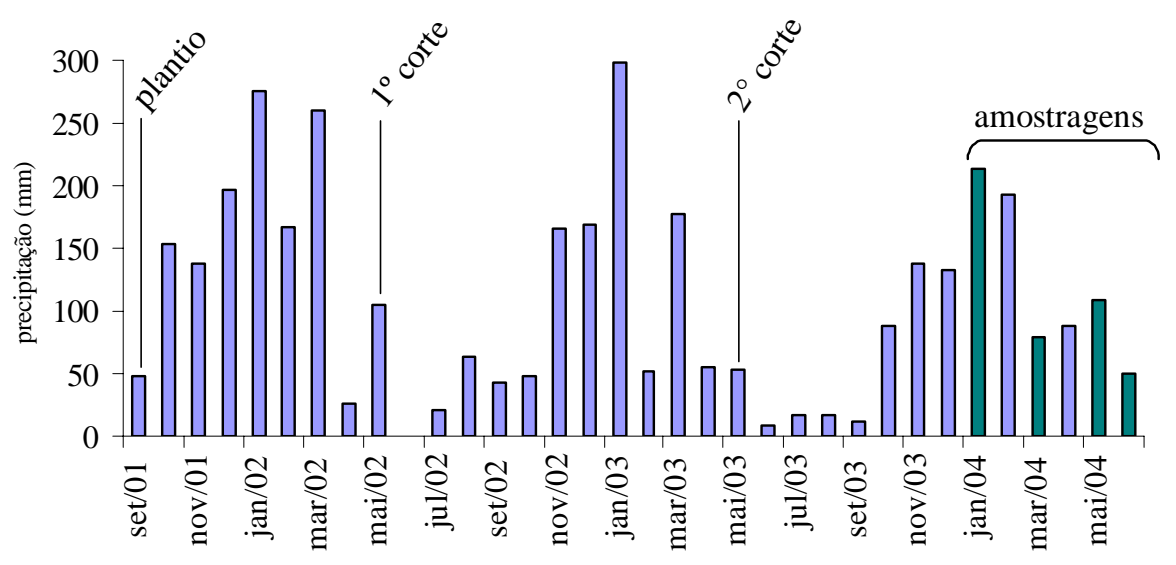

Figura 5 - Pluviometria durante o desenvolvimento da cultura, sendo que as barras verdes representam os meses de amostragem em campo

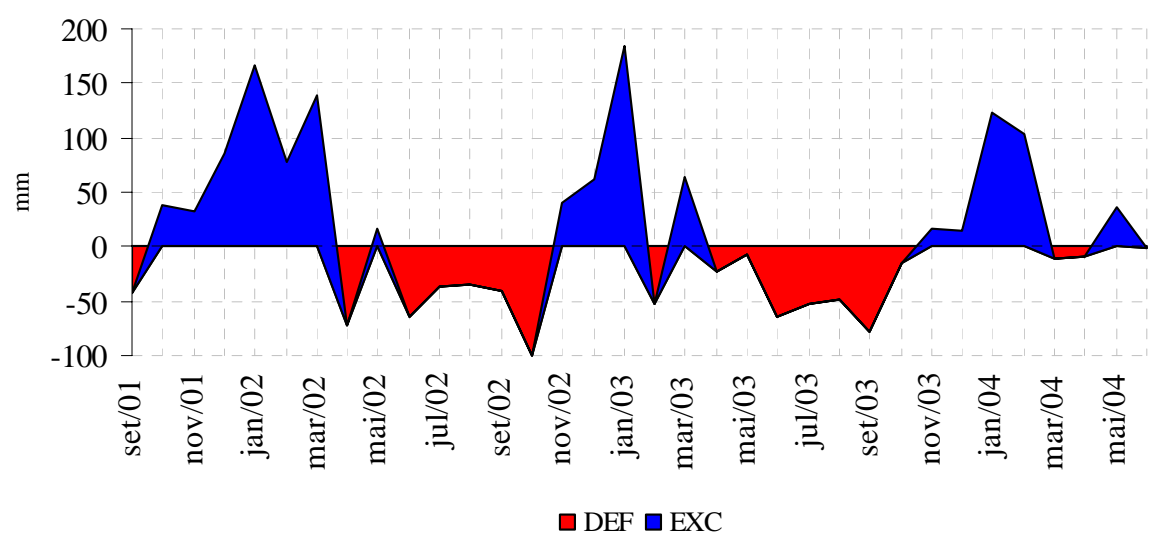

Figura 6 - Extrato do balanço hídrico durante o desenvolvimento da cultura, dado pela deficiência (DEF) e excesso (EXC) hídricos

A morte do sistema radicular da cana-de-açúcar ocorre, de acordo com Aguiar (1978) e Vasconcelos (2002b), com a deficiência hídrica, independente da fase de desenvolvimento, sendo sua renovação dependente do fim do período de falta de água no solo, com o início das chuvas. A primeira (19/1/04) e a terceira (11/5/04) amostragens foram realizadas com excedente hídrico. Na segunda (10/3/04), a cultura passava por um período curto de deficiência hídrica, e na última (22/06/04) iniciava-se um período de maior estiagem, com a diminuição das chuvas. 


\subsection{Densidade do solo}

Os valores de densidade do solo, na linha e na entrelinha da cultura (distante 70 cm da linha), por épocas e por profundidades, são apresentados nas Figuras 7 e 8 respectivamente.

Em janeiro (primeira amostragem) a densidade do solo variou de 1,47 a $1,59 \mathrm{~g} \mathrm{~cm}^{-3}$, sendo que na linha da cultura a densidade foi maior do que na entrelinha na profundidade de 60 a $80 \mathrm{~cm}$. As maiores densidades foram observadas entre 20 e $40 \mathrm{~cm}$ de profundidade. Em março (segunda amostragem) as densidades do solo na linha e na entrelinha não diferiram, sendo que os maiores valores foram encontrados na superfície, 1,55 $\mathrm{g} \mathrm{cm}^{-3}$ em média. Em maio (terceira amostragem) as densidades variaram de 1,44 a $1,58 \mathrm{~g} \mathrm{~cm}^{-3}$. Os valores para linha e entrelinha diferiram nas profundidades de 0 a 20 e de 40 a $60 \mathrm{~cm}$, sendo a densidade na linha superior a da entrelinha. Em junho (última amostragem) somente na profundidade 40 a 60 cm não houve diferença na densidade de linha e entrelinha. Nas demais profundidades a densidade na linha foi maior, com valor máximo de $1,60 \mathrm{~g} \mathrm{~cm}^{-3}$.

Valores de densidades de solo atingindo 1,64 $\mathrm{g} \mathrm{cm}^{-3}$ foram observados por Vasconcelos (2002b), em trabalho realizado na região de Ribeirão Preto nos $20 \mathrm{~cm}$ superficiais de um Latossolo Vermelho distrófico de textura média, e foram atribuídos ao tráfego intenso de máquinas na operação de colheita mecanizada. Para densidade do solo acima de $1,45 \mathrm{~g} \mathrm{~cm}^{-3}$ as raízes não encontram boas condições para suprir a parte aérea das plantas com níveis satisfatórios de nutrientes (Fernandes et al., 1983).

A partir da terceira amostragem houve diferença entre a densidade do solo na linha e na entrelinha nos $20 \mathrm{~cm}$ superficiais, sendo maior na linha. De 20 a $40 \mathrm{~cm}$ a densidade só foi diferente na quarta amostragem, sendo maior na linha. Na profundidade de 40 a $60 \mathrm{~cm}$ a densidade foi diferente para linha e entrelinha na terceira amostragem. Na profundidade de 60 a $80 \mathrm{~cm}$ a densidade não diferiu na segunda amostragem. Com exceção da profundidade 20 a 40 cm, a tendência observada com o passar do tempo foi de aumento na densidade do solo, principalmente na linha da cultura. 


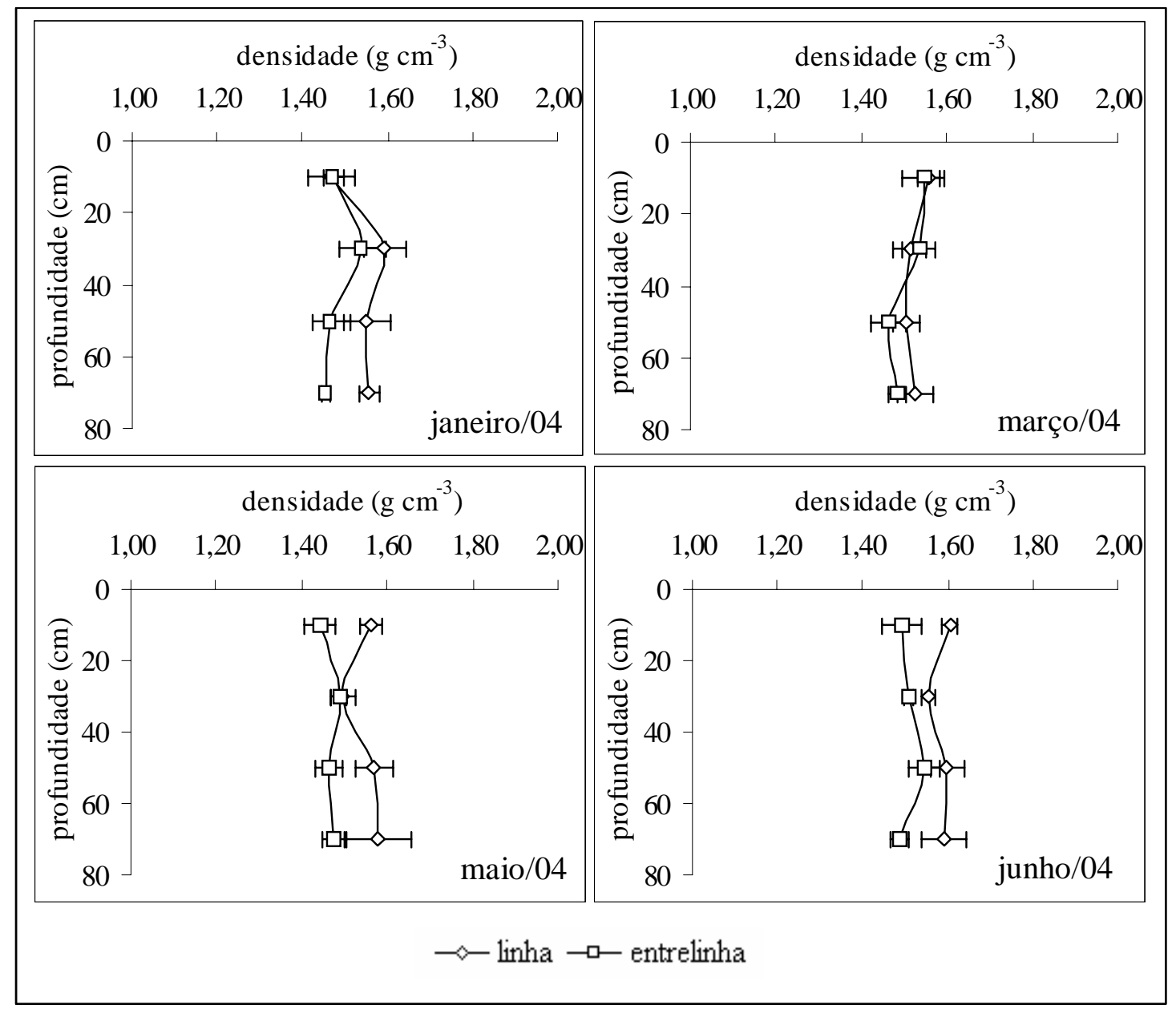

Figura 7 - Densidade $\left(\mathrm{g} \mathrm{dm}^{-3}\right)$ média do solo em diferentes profundidades na linha e entrelinha da cultura, em janeiro, março, maio e junho de 2004; as barras representam o desvio padrão da média $(\mathrm{n}=4)$

As raízes influenciam o arranjo das partículas do solo, pois a absorção de água pelas raízes causa secamento das partículas de solo adjacente, provocando pressões capilares que comprimem os grânulos. Dessa forma, as raízes atuam diretamente sobre a agregação do solo por meio da pressão exercida, aproximando as partículas primárias e microagregados, e indiretamente por meio da produção de exsudatos radiculares que provocam intenso desenvolvimento microbiano, por sua vez sintetizando polissacarídeos e ácidos húmicos de elevado poder agregante (Anghinoni \& Meurer, 1999). 


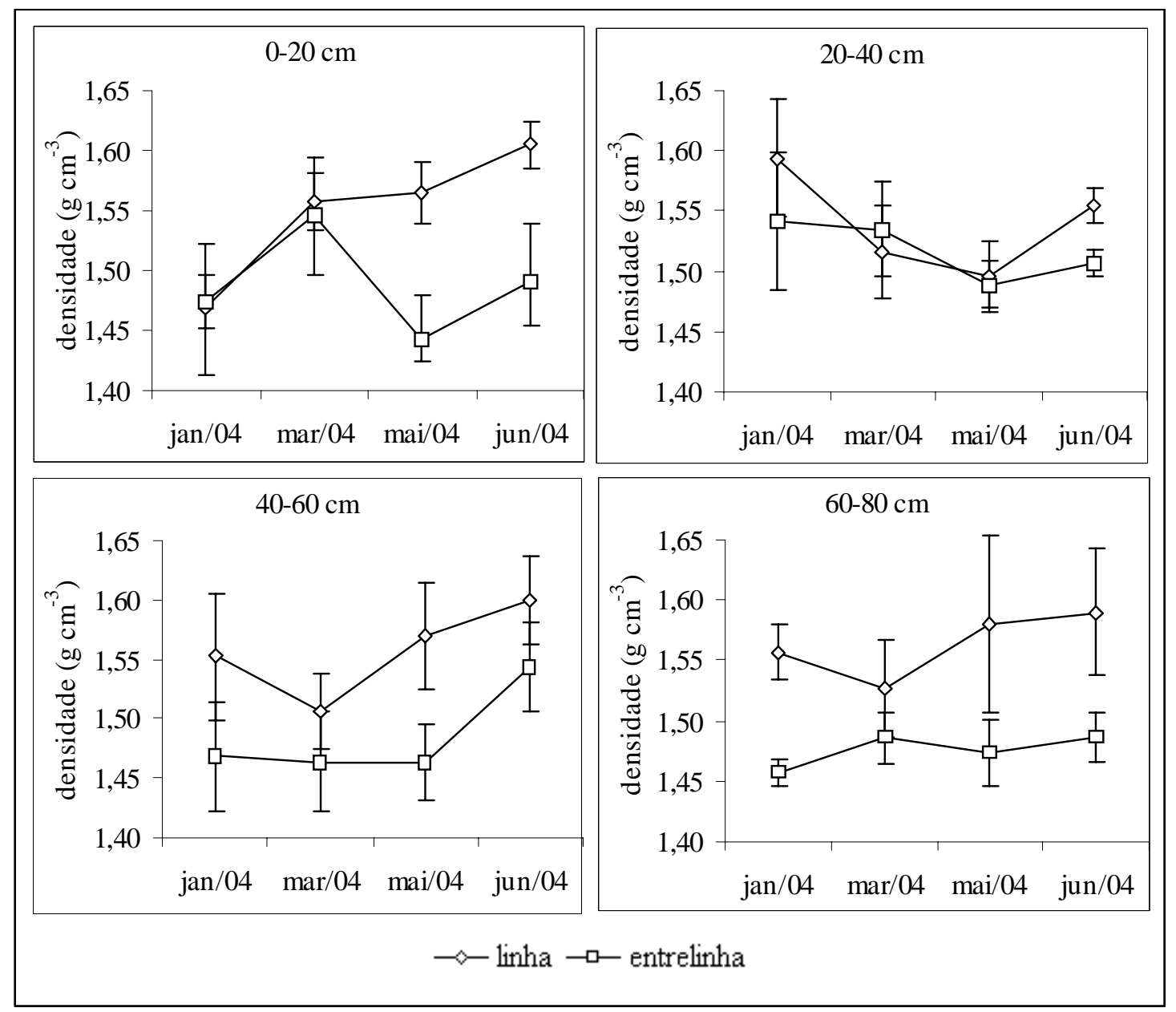

Figura 8 - Densidade $\left(\mathrm{g} \mathrm{dm}^{-3}\right)$ média do solo, na linha e na entrelinha da cultura, nas profundidades de 0-20, 20-40, 40-60 e 60-80 cm, em função das épocas de amostragem; as barras representam o desvio padrão da média $(n=4)$

Vasconcelos (2002b), avaliando densidade do solo cultivado com cana-de-açúcar colhida mecanicamente, observou que as maiores densidades ocorriam na linha e a 35 cm da linha de brotação, superiores ao meio da entrelinha onde foi realizada a subsolagem, por ocasião da adubação. Conforme o autor, esse efeito foi causado pela transmissão de força impressa pelo rodado das máquinas ao longo das partículas do solo. Outro fator que causa o aumento na densidade do solo na linha da cultura da cana-deaçúcar é o tráfego direto do rodado das máquinas sobre esta, durante as operações envolvidas na colheita, principalmente quando os operadores movimentam os 
transbordos lateralmente para igualar a carga na colheita mecanizada, ou quando as bitolas dos equipamentos não combinam com o espaçamento da cultura, resultando em enfraquecimento da soqueira e, conseqüente, redução na produtividade (Braunack \& Peatey, 1999).

Outra operação mecanizada que altera a densidade e a porosidade do solo, principalmente na entrelinha, é a tríplice operação realizada no cultivo da soca da canade-açúcar, representada pela subsolagem ou gradagem, adubação e escarificação. Paulino et al. (2004) estudando essa operação em um Latossolo Vermelho distroférrico no Paraná, constataram que o tríplice cultivo alterou a densidade, a macro e a microporosidade do solo. A escarificação reduziu a densidade e a microporosidade, e aumentou a macroporosidade do solo, melhorando suas características físicas para o desenvolvimento radicular.

Salata et al. (1987) estudando a importância do tipo de sulcador no desenvolvimento do sistema radicular de cana-de-açúcar, concluíram que independentemente da variedade testada, quando usado o sulcador-escarificador foram obtidos os melhores desempenhos em produtividade, o que estava diretamente relacionado ao desenvolvimento do sistema radicular. A escarificação propiciou às raízes melhores condições de exploração do solo em profundidade.

\subsection{Umidade do solo}

A umidade do solo, na linha e na entrelinha da cultura, para épocas de amostragem e por profundidades constam da Figuras 9 e 10 respectivamente.Os valores de umidade não diferiram, nas quatro amostragens, em ambas as posições na linha e entrelinha, nas profundidades amostradas, a não ser nos $20 \mathrm{~cm}$ superficiais em maio.

De forma geral, houve o aumento da umidade do solo com a profundidade em todas as épocas de amostragem variando de 9,1 a 12,8\% em janeiro, de 13,5 a 14,2\% em março, de 9,9 a 13,0\% em maio, e de 10,0 a 14,0\% em junho, em média. 


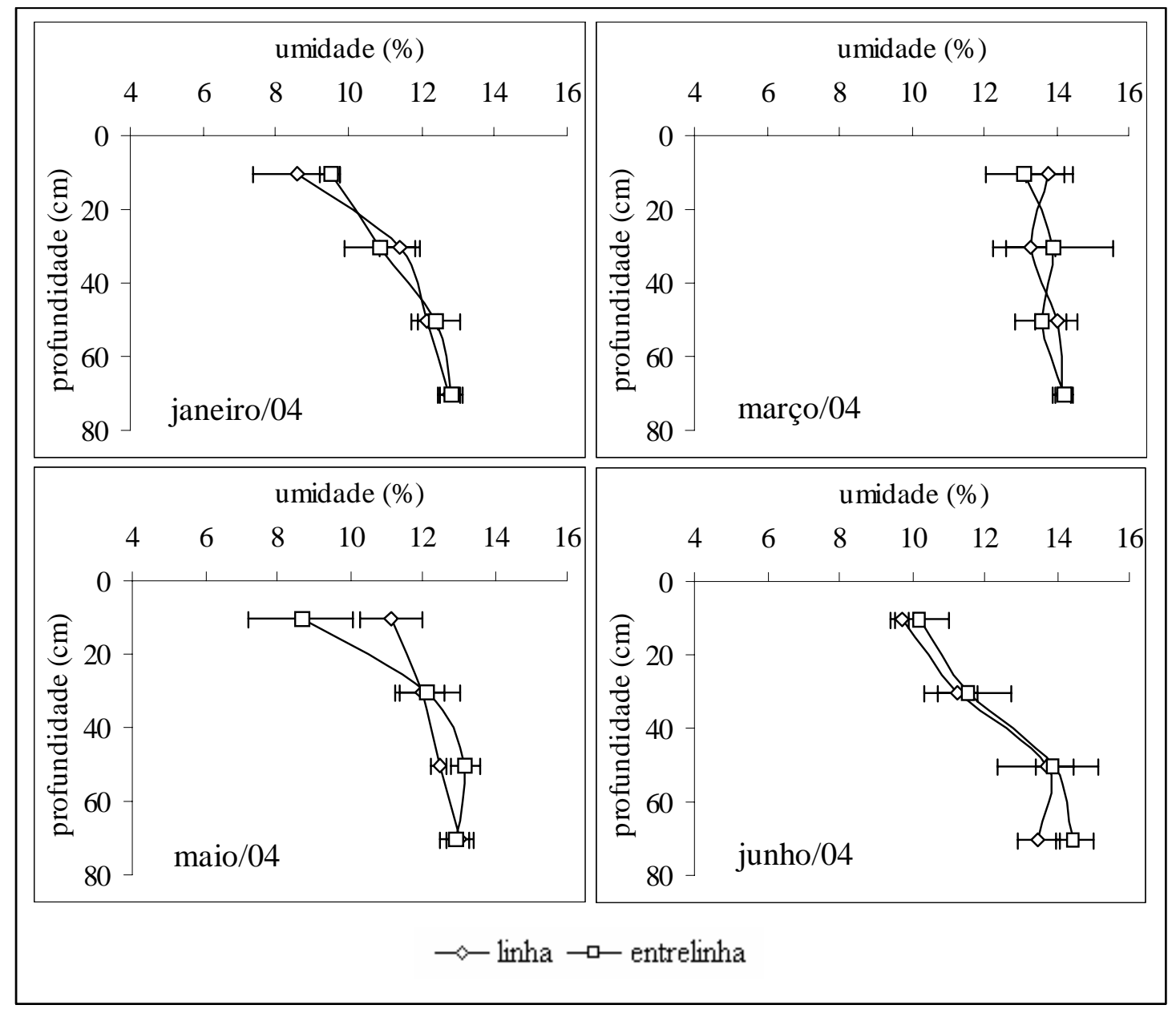

Figura 9 - Umidade (\%, m/m) média do solo e sua distribuição no perfil, na linha e entrelinha da cultura, em janeiro, março, maio e junho de 2004; as barras representam o desvio padrão da média $(n=4)$

A umidade do solo também não diferiu entre a linha e entrelinha quando analisada por profundidade, nas épocas de amostragem, com exceção para a camada superficial em maio (Figura 10). As maiores variações de umidade foram encontradas nas camadas superficiais, de 9 a 14\%, sendo que nas camadas mais profundas a umidade foi mais constante variando de 12 a $14 \%$ de $40-60 \mathrm{~cm}$, e de 13 a $14 \%$ de $60-80 \mathrm{~cm}$. Vasconcelos (2002b) encontrou valores próximos aos do presente trabalho, em solo de textura média, sendo que no período seco a umidade não ultrapassou 13,2\% e no período úmido foram superiores a esse valor. 
A menor umidade na camada superficial do solo, profundidade na qual a reserva de água disponível reduz-se mais rapidamente, é prejudicial à planta quando o sistema radicular se desenvolve nessa região. $\mathrm{O}$ menor desenvolvimento radicular em subsuperfície pode ocorrer por impedimentos físicos ou químicos. Segundo Yang (1977) as operações mecanizadas realizadas sob condições de solo seco, tem efeitos reduzidos na compactação do solo, fato que deixa de ser observado quando a umidade da superfície do solo é mantida pela palha, por exemplo.

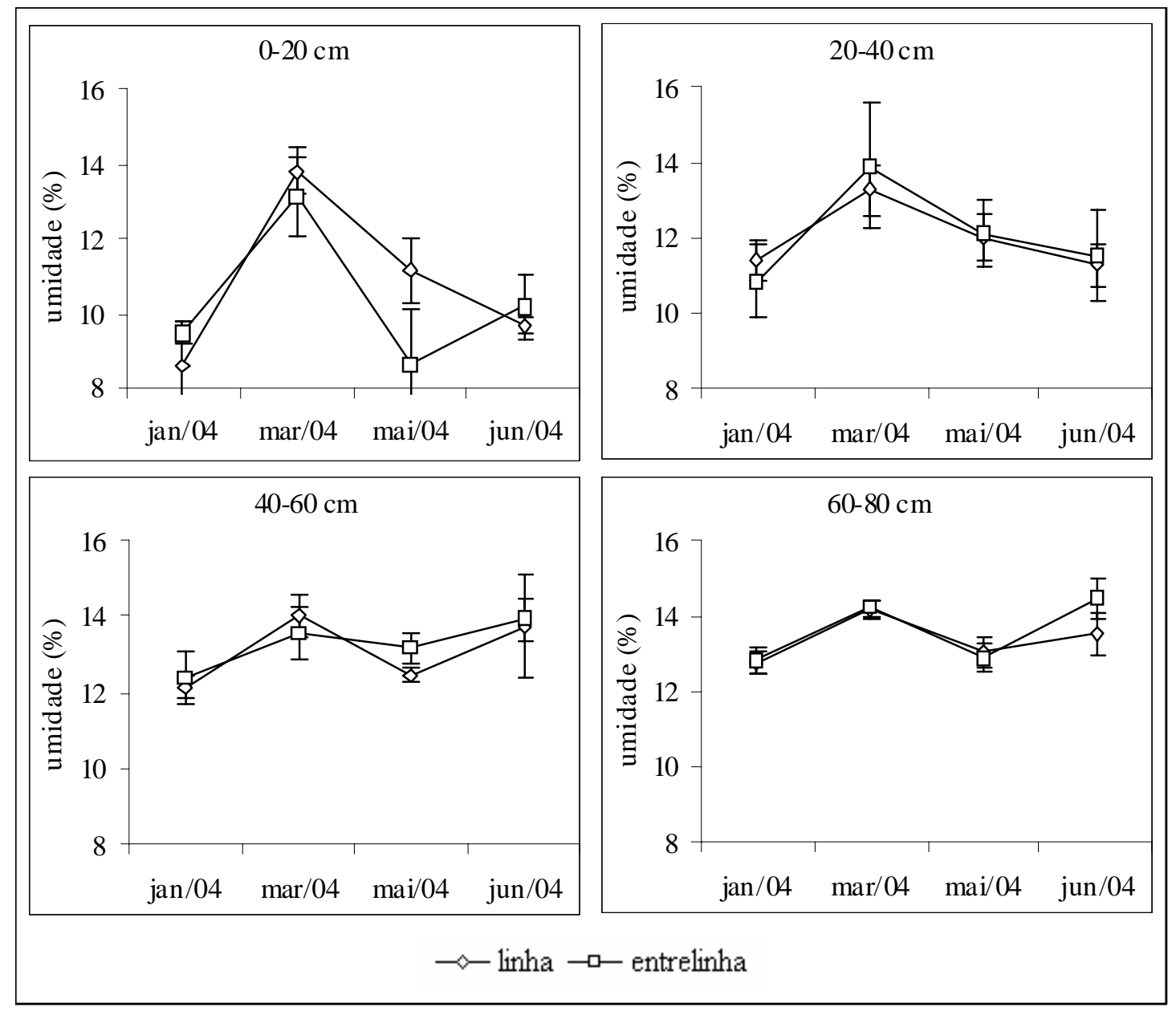

Figura 10 - Variação da umidade (\%, m/m) média do solo, na linha e na entrelinha da cultura, nas profundidades de 0-20, 20-40, 40-60 e 60-80 cm, em função das épocas de amostragem; as barras representam o desvio padrão da média $(\mathrm{n}=4)$ 


\subsection{Desenvolvimento da parte aérea da planta}

Em janeiro de 2004 as plantas da área experimental estavam no $8^{\circ}$ mês de desenvolvimento da $2^{\circ}$ soqueira ou do $3^{\circ}$ ciclo. A Figura 11 mostra a evolução da produtividade da área, em toneladas por hectare de massa natural (úmida) e seca, de colmos mais ponteiros.

As produtividades foram de 81, 87, 96 e $98 \mathrm{t} \mathrm{ha}^{-1}$ em massa natural, e 22, 26, 32 e $31 \mathrm{t} \mathrm{ha}^{-1}$ em massa seca para janeiro, março, maio e junho de 2004 respectivamente. As massas úmidas de janeiro e março não diferiram entre si, e foram diferentes das de maio e junho, que por sua vez não diferiram. As massas secas não diferiram estatisticamente em maio e junho, sendo menores nos primeiros meses, aumentando com o tempo.

Orlando Filho et al. (1980) observaram, para cana soca, que a produção de massa seca pelas folhas foi superior à dos colmos até o $6^{\circ}$ mês de idade, tornando-se inferior a partir do $8^{\circ}$ mês até o final do ciclo. Inforzato \& Alvarez (1957) constataram que o desenvolvimento do sistema radicular em cana planta, dos 6 aos 12 meses mostrou estreita relação com o crescimento da parte aérea.

A parte aérea e o sistema radicular da cana-de-açúcar competem por fotoassimilados, o que tem conseqüências desfavoráveis para a produtividade e acúmulo de sacarose. Para o vegetal, a capacidade de sobrevivência é fator preponderante, sendo que a manutenção de uma arquitetura radicular com maior quantidade de raízes significa maior quantidade de reservas metabólicas, enquanto a maior distribuição em profundidade, apesar de reduzir a altura dos colmos, confere a planta maior possibilidade de contato com camadas mais úmidas e menor estresse em períodos de deficiência hídrica. Estes processos resultam em maior demanda para o sistema radicular da energia que poderia ser exportada na colheita (Vasconcelos, 2002b). 


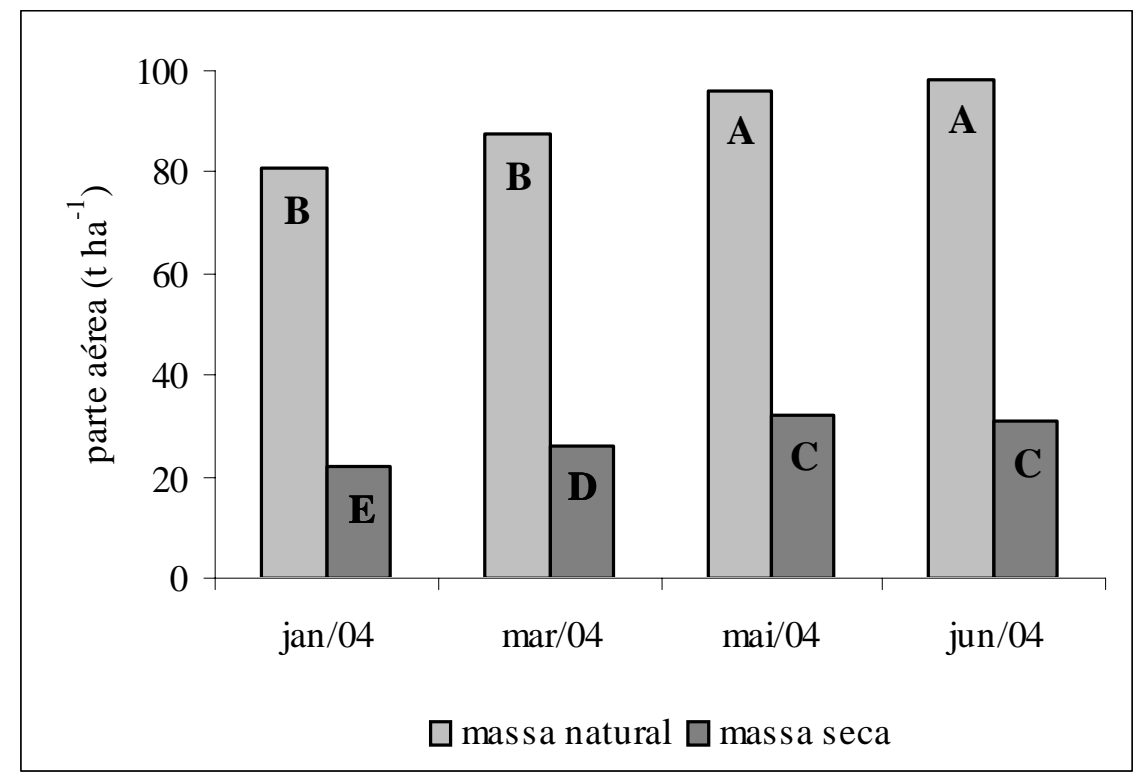

Figura 11 - Massa seca e natural da parte aérea (colmos + ponteiros), em $\mathrm{t} \mathrm{ha}^{-1}$, nas quatro épocas de amostragem; letras diferentes representam diferença significativa a $5 \%$ de probabilidade pelo teste $\mathrm{F}$

\subsection{Desenvolvimento e distribuição do sistema radicular: método do monólito}

O método o monólito foi considerado padrão na avaliação do desenvolvimento e distribuição do sistema radicular da cana-de-açúcar, pois segundo Köpke (1981) permite estimar a quantidade total de raízes, com grande exatidão, apesar de apresentar baixa precisão e ser de difícil execução.

Como pode ser observado na Figura 12, o sistema radicular (rizomas + raízes) aumentou de janeiro a maio, apesar de o primeiro mês de amostragem ter sido o $8^{\circ}$ mês de desenvolvimento da cultura após o corte. Vasconcelos (2002b) também observou aumento significativo da massa de raízes de janeiro para maio em todas as profundidades avaliadas. As massas secas do sistema radicular nas amostragens de janeiro, março, maio e junho de 2004 foram, respectivamente, 4,4; 5,7; 5.9; e 6,3 t ha-1, com valor médio de 5,6 $\mathrm{t} \mathrm{ha}^{-1}$, sendo $3,8 \mathrm{t} \mathrm{ha}^{-1}$ de raízes e $1,8 \mathrm{t} \mathrm{ha}{ }^{-1}$ de rizomas. 


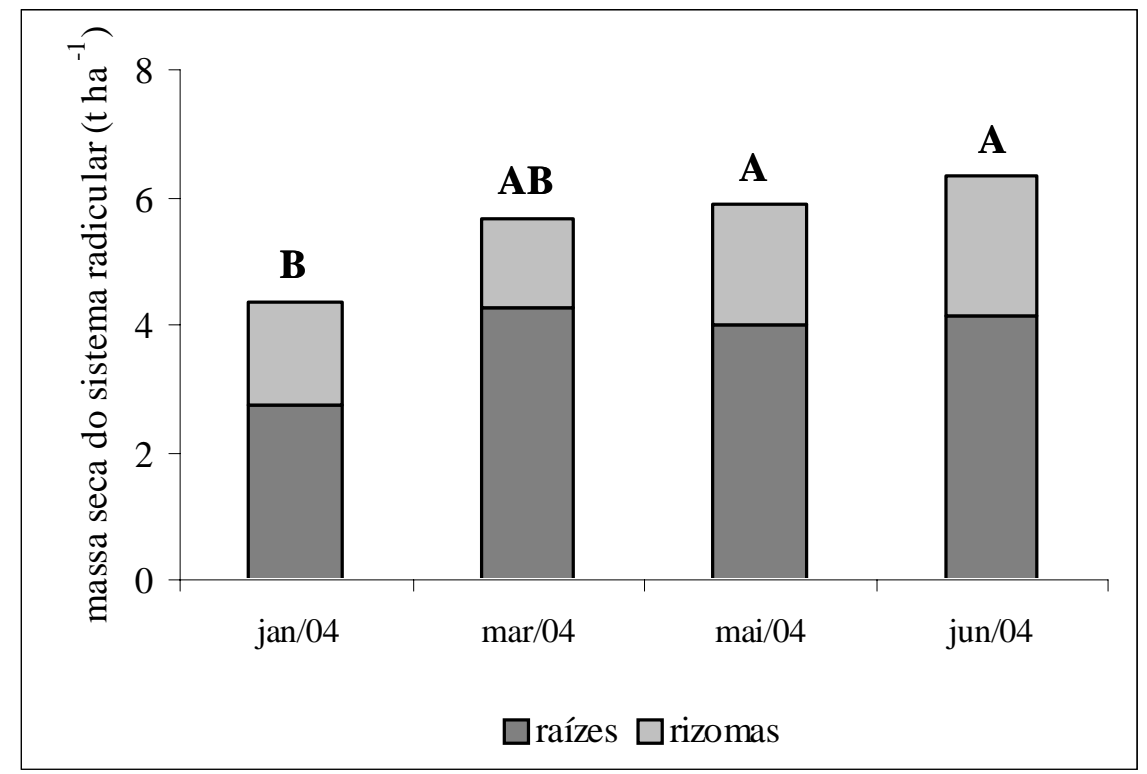

Figura 12 - Massa seca do sistema radicular, raízes e rizomas, em $\mathrm{t} \mathrm{ha}^{-1}$, nas quatro épocas de amostragem; letras diferentes representam diferença significativa a $5 \%$ de probabilidade pelo teste $\mathrm{F}$

Inforzato \& Alvarez (1957) trabalhando com cana planta encontraram, aos 6 meses após o plantio, 1,8 t ha ${ }^{-1}$ de raízes. No período de 6 a 12 meses houve incremento na massa de raízes sendo encontradas $8,0 \mathrm{t} \mathrm{ha}^{-1}$ aos 12 meses. Esses resultados foram superiores aos do presente trabalho, com a cultura no $3^{\circ}$ ciclo. No entanto, os autores citam em seu trabalho que aos 18 meses o sistema radicular apresentava menor massa que aos 12 meses, sendo encontrada certa quantidade de raízes mortas, não computadas em virtude do estudo restringir-se às raízes em atividade. Essa pode ser uma das razões das diferenças encontradas entre as massas dos sistemas radiculares entre este trabalho e o de Inforzato e Alvarez (1957), além das diferenças edafoclimáticas, varietais e de ciclo da cultura.

Não houve diferença pronunciada da massa do sistema radicular e de sua distribuição no perfil do solo de uma amostragem para outra, pelo fato de a cultura já estar em seu $8^{\circ}$ mês de desenvolvimento e, também, por não ter havido um período de 
deficiência hídrica severa, o qual poderia ter causado morte de raízes nos meses precedentes as amostragens.

Em relação a distribuição de raízes em profundidade (Figura 13A), 74\% das raízes, em média, localizaram-se nos $20 \mathrm{~cm}$ superficiais do solo, não existindo muita variação entre as épocas de amostragem. Considerando os primeiros $40 \mathrm{~cm}$ superficiais, essa porcentagem aumenta para 92\%, restando 8\% das raízes de 40 a $80 \mathrm{~cm}$ de profundidade. A distribuição das raízes em relação à linha de plantio (Figura 13B), apresentou, em média, 65\% das raízes localizadas na linha, 18\% de 14 a $42 \mathrm{~cm}$ da linha e $17 \%$ de 42 a $70 \mathrm{~cm}$ da linha. As distribuições porcentuais das raízes no perfil do solo mostram maior densidade radicular superficialmente e em torno da touceira da cana.

Vários trabalhos apresentaram dados da distribuição de raízes de cana-de-açúcar no solo com valores parecidos aos deste trabalho. Lee (1926), nas Ilhas Havaianas, verificou que $65 \%$ das raízes encontravam-se nos $20 \mathrm{~cm}$ superficiais do solo, e que $85 \%$ encontravam-se até $60 \mathrm{~cm}$ de profundidade, considerando a aeração do solo o principal fator para que as raízes da cana-de-açúcar tenham boa superfície para absorção de água e nutrientes. Jensen (1951), em Cuba, observou emissão de grande quantidade de raízes de cana-de-açúcar próximo à superfície do solo e que as variedades diferiam pouco na distribuição de suas raízes, sendo que em todos os casos estudados mais de $50 \%$ delas encontravam-se nos $20 \mathrm{~cm}$ superficiais do solo.
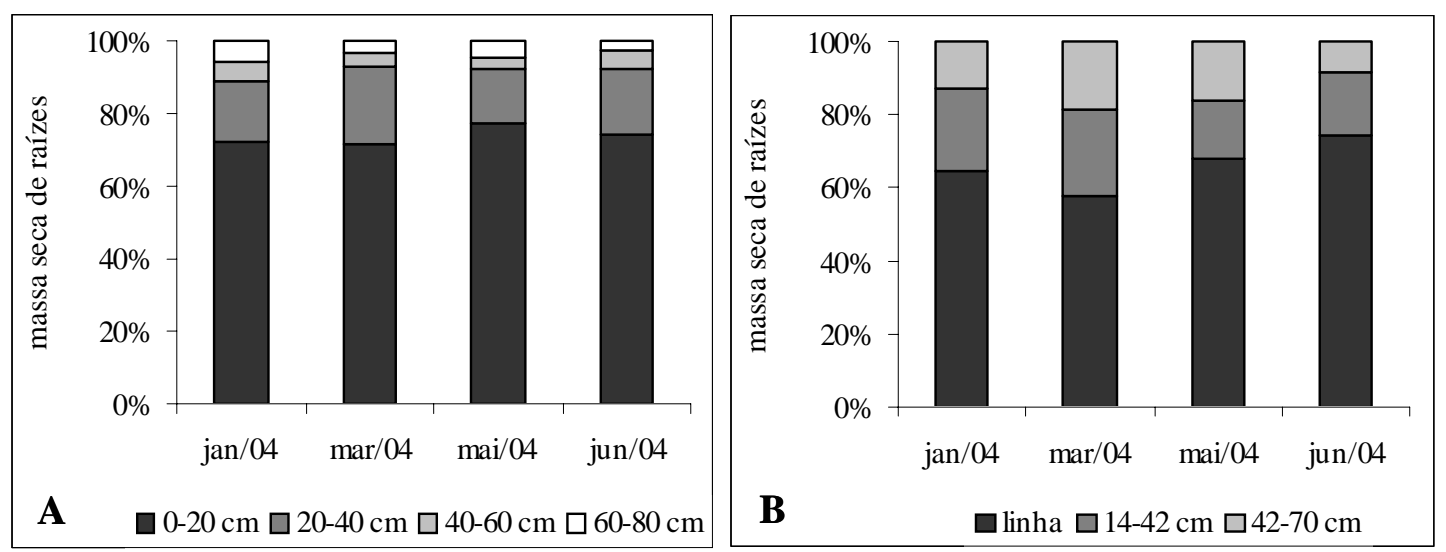

Figura 13 - Porcentagem de raízes no perfil do solo em profundidade (A) e em diferentes distâncias da linha de plantio (B), nas quatro épocas de amostragem 
Da análise dos resultados encontrados na Figura 14, observando-se os locais de colheita de amostras no perfil do solo, em cada época, fica claro o acúmulo de massa do sistema radicular na superfície e na linha. Em janeiro a massa seca de raízes na linha e a $20 \mathrm{~cm}$ de profundidade era de 2,02 $\mathrm{g} \mathrm{dm}^{-3}$ e em junho, na última amostragem, era de $3,68 \mathrm{~g} \mathrm{dm}^{-3}$, diferindo estatisticamente. Nos outros locais, a variação espacial de raízes foi elevada, no entanto, não apresentou padrões definidos de acréscimo, decréscimo ou estabilidade da massa do sistema radicular, sendo que na maioria das observações de 40 a $80 \mathrm{~cm}$ e de 14 a $70 \mathrm{~cm}$ da linha os valores não diferiram da média.

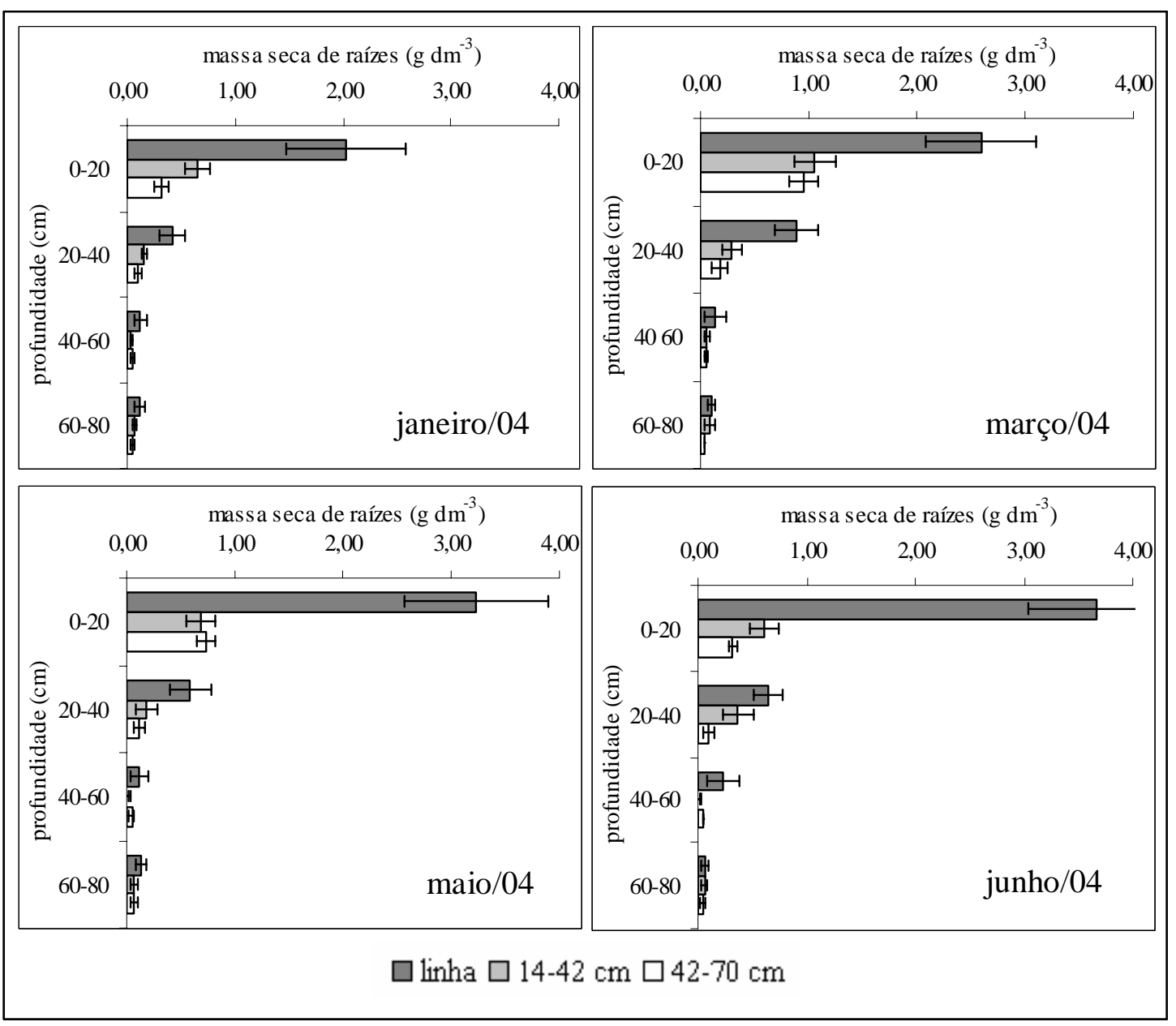

Figura 14 - Distribuição de raízes $\left(\mathrm{g} \mathrm{dm}^{-3}\right)$ no perfil do solo em janeiro, março, maio e junho de 2004; as barras representam o desvio padrão da média $(\mathrm{n}=4)$ 
Inforzato \& Alvarez (1957) encontraram, aos 12 meses de desenvolvimento da cultura, $71 \%$ das raízes localizadas nos primeiros $30 \mathrm{~cm}$ de profundidade, sendo que $61 \%$ destas situavam-se nos primeiros $20 \mathrm{~cm}$ do solo. Aos 18 meses o sistema radicular nos $30 \mathrm{~cm}$ superficiais correspondeu a 66\% da massa radicular. Todos esses valores também são próximos aos encontrados no presente trabalho. Korndörfer et al. (1989) verificaram que no perfil do solo não ocorriam variações significativas na distribuição de raízes entre variedades, sendo que na cana planta a porcentagem de raízes na camada de 0 a $30 \mathrm{~cm}$ variou de 89 a 92\%, entre variedades, e na cana soca a porcentagem de raízes na camada de 0 a $40 \mathrm{~cm}$ variou de 85 a 92\%. Segundo Anghinoni \& Meurer (1999), o aumento da densidade de raízes, em uma fração restrita de solo pode limitar a absorção de nutrientes pelas plantas, mesmo que haja alta concentração em forma disponível, pois o decréscimo da umidade do solo, causado pela alta demanda das raízes, aumenta a salinidade e diminui a intensidade do processo de difusão.

Alvarez (2000) verificou que o sistema radicular além de concentrar-se mais na superfície, também tem presença marcante na proximidade do eixo da touceira, como encontrado no presente trabalho. Sampaio et al. (1987) identificaram, para as condições do nordeste brasileiro, que $75 \%$ da massa radicular da cana-de-açúcar localizavam-se nos primeiros $20 \mathrm{~cm}$ superficiais e 50\% das raízes estavam distantes a menos de $30 \mathrm{~cm}$ da touceira. Deve-se considerar que existe uma pressão resultante do manejo da cultura, principalmente em relação ao tráfego na entrelinha, que diminui a porosidade e conseqüentemente a aeração do solo.

Como a densidade de solo não alterou-se muito em profundidade, bem como a umidade, um dos fatores que podem ter dificultado o desenvolvimento do sistema radicular das plantas e limitado sua distribuição em profundidade, além da baixa aeração, foi a elevada saturação em alumínio (m\%) da camada de 40 a 80 cm, chegando a 50\% na profundidade de 60 a $80 \mathrm{~cm}$.

De acordo com Furlani (1983) além do alto teor de alumínio no solo ser tóxico às plantas e diminuir o desenvolvimento radicular, pode ainda provocar a fixação de fósforo em formas menos disponíveis, diminuindo a taxa de respiração e interferindo em reações enzimáticas responsáveis pela deposição de polissacarídeos nas paredes 
celulares, além de modificar a dinâmica de absorção e transporte de vários nutrientes, principalmente Ca e Mg. O cálcio é fundamental para o crescimento das raízes sendo essencial na divisão celular e para a manutenção da funcionalidade da membrana, além de complexar o alumínio tóxico (Marschner et al., 1996; Havlin, et al., 1999). A diminuição nos teores de cálcio em profundidade podem ter contribuído para pequeno desenvolvimento do sistema radicular. A correção superficial da acidez do solo também restringe o crescimento das raízes às camadas superiores deste, onde a reserva de água disponível é menor (Raij, 1991).

\subsection{Análise comparativa dos métodos de amostragem de sistema radicular para massa seca de raízes}

As amostragens da massa seca do sistema radicular pelos métodos do monólito e da sonda diferiram estatisticamente na profundidade de 40 a $60 \mathrm{~cm}$, na média das quatro épocas de amostragem (Figura 15).

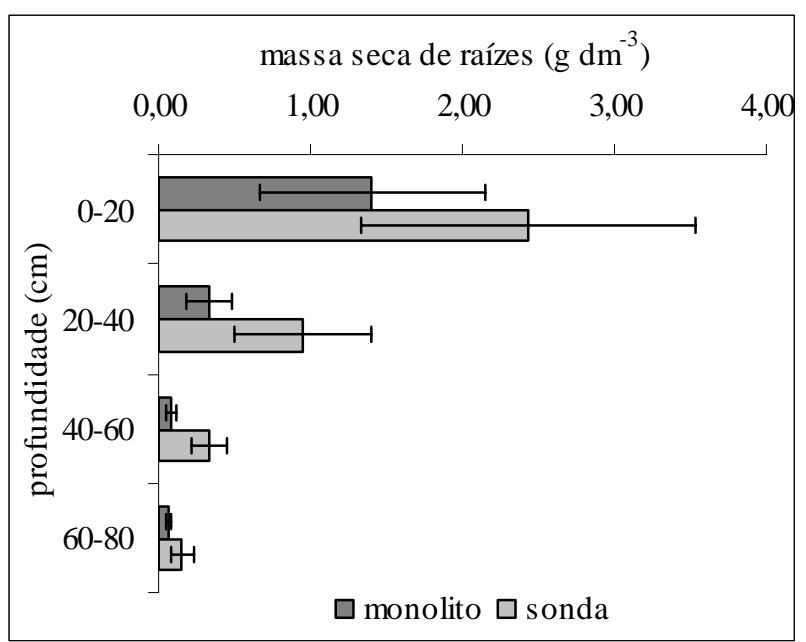

Figura 15 - Massa seca de raízes $\left(\mathrm{g} \mathrm{dm}^{-3}\right.$ ) pelos dois métodos de amostragem: monólito e sonda, para avaliação da distribuição de raízes no perfil do solo, na média das quatro épocas de amostragem; as barras representam o desvio padrão da média $(\mathrm{n}=4)$ 
Embora os valores para outras profundidades não tenham diferido pela observação dos desvios padrões das médias, o método da sonda mostrou sistematicamente maiores quantidades médias de raízes em comparação ao método do monólito.

Ambos os métodos mostraram que houve aumento da massa do sistema radicular amostrado, na média do perfil do solo, de janeiro para os meses seguintes, sendo que nestes os valores encontrados não foram diferentes entre si (Tabela 4). Os métodos, para as médias gerais, mostraram-se equivalentes apenas em janeiro, tendo a sonda nos outros meses superestimado a massa do sistema radicular em relação ao monólito.

Em cada época de amostragem (Figura 16), os métodos mostraram-se diferentes para as profundidades de 0 a 20, 20 a 40 e 40 a $60 \mathrm{~cm}$ em março; de 20 a $40 \mathrm{~cm}$ em maio; e de 40 a 60 e 60 a $80 \mathrm{~cm}$ em junho. Para todas as outras amostragens os métodos não diferiram, apesar do método da sonda continuar superestimando a quantidade de raízes amostradas.

Tabela 4. Massa seca de raízes ( $\mathrm{g} \mathrm{dm}^{-3}$ ) de todo perfil do solo, de entrelinha a entrelinha, amostradas pelos métodos do monólito e da sonda, em quatro épocas de amostragens $(\mathrm{n}=16)$

\begin{tabular}{ccc}
\hline Época de amostragem & Monólito & Sonda \\
\hline Janeiro/2004 & $0,35 \mathrm{Ab}$ & $\mathrm{g} \mathrm{dm}^{-3}$ \\
Março/2004 & $0,53 \mathrm{Ba}$ & $1,25 \mathrm{Aa}$ \\
Maio/2004 & $0,50 \mathrm{Ba}$ & $0,94 \mathrm{Aa}$ \\
Junho/2004 & $0,52 \mathrm{Ba}$ & $1,08 \mathrm{Aa}$ \\
Média & $0,48 \mathrm{~B}$ & $0,97 \mathrm{~A}$ \\
CV (\%) & 17,7 & 29,1 \\
\hline
\end{tabular}

Médias seguidas de mesma letra não diferem entre si pelo teste de Tukey a 5\% de probabilidade, sendo que as letras maiúsculas comparam médias nas linhas e as minúsculas nas colunas. 


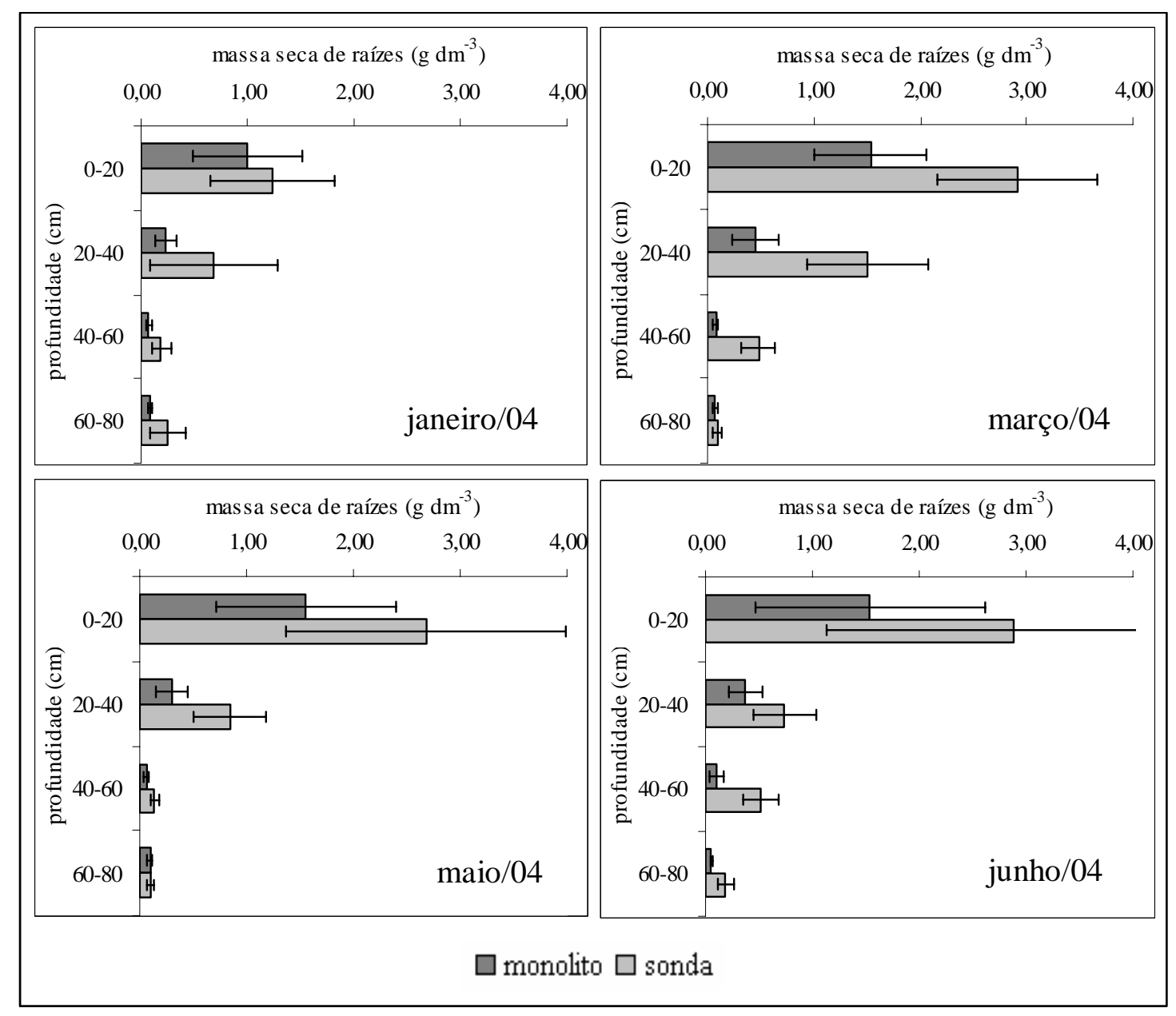

Figura 16 - Massa seca de raízes $\left(\mathrm{g} \mathrm{dm}^{-3}\right.$ ) obtidas pelos métodos de amostragem monólito e sonda, no perfil do solo, em janeiro, março, maio e junho de 2004; as barras representam o desvio padrão da média $(n=4)$

O método do monólito apresentou menor coeficiente de variação em comparação ao da sondagem ou da tradagem, muito provavelmente por amostrar maior volume de solo (Kücke et al., 1995). A distribuição do sistema radicular no solo apresentou considerável variabilidade espacial, mostrando maior relação com o tamanho das amostras que com o número delas (Fante Junior, 1999).

A superestimativa da massa radicular pela sonda pode ocorrer pela maior concentração de raízes no ponto de amostragem, não representando uma distribuição média destas. Além das condições edafoclimáticas, a época de amostragem também 
pode interferir neste particular, já que com o tempo ocorre alteração da distribuição espacial das raízes no solo, tanto em profundidade, quanto em relação a distância da linha da cultura.

Vasconcelos et al. (2003) utilizando trado para a amostragem de raízes de canade-açúcar, verificou que além do método superestimar a massa de raízes amostradas em comparação com o monólito, o uso de duas subamostras não se mostrou adequado à quantificação das raízes na comparação com o método do monólito, sugerindo que o aumento do número destas pode melhorar a representatividade do método.

O que pode ter colaborado para que os métodos não diferissem neste trabalho foi a própria falta de uniformidade na distribuição espacial do sistema radicular no solo e a baixa repetibilidade dos dados, fazendo com que os desvios se apresentassem elevados. No entanto, dificilmente serão encontrados desvios e coeficientes de variação baixos, já que a quantificação do crescimento do sistema radicular em campo, por qualquer método de amostragem, é um desafio em função de alguns fatores, tais como: a arquitetura geométrica complexa do sistema radicular, a diversidade de tipos e diâmetros das raízes, as diferentes atividades fisiológicas em raízes de diferentes idades, o rápido crescimento e decomposição de raízes finas, os processos microbiológicos que ocorrem na interface solo-raiz e a variabilidade do ambiente edáfico no qual as raízes se desenvolvem (Luxmoore \& Stolzy, 1987; Fante Junior, 1999).

\subsection{Massa seca de raízes metabolicamente ativas quantificadas pelo método do monólito e pela diluição isotópica}

Comparando a massa seca de raízes metabolicamente ativas (vivas) com o total de raízes (Figura 17), pelo método do monólito, pode-se observar que, apesar de as raízes vivas aumentarem no decorrer das amostragens concomitantemente com as raízes totais, elas diferem entre si nas camadas do solo onde se concentram 92\% das raízes (020 e 20-40 cm de profundidade), sendo estatisticamente iguais nos meses de março, maio e junho, nas profundidades de 40 a 60 e 60 a $80 \mathrm{~cm}$, o que também foi verificado por Vasconcelos (2002b) nessas mesmas profundidades. 


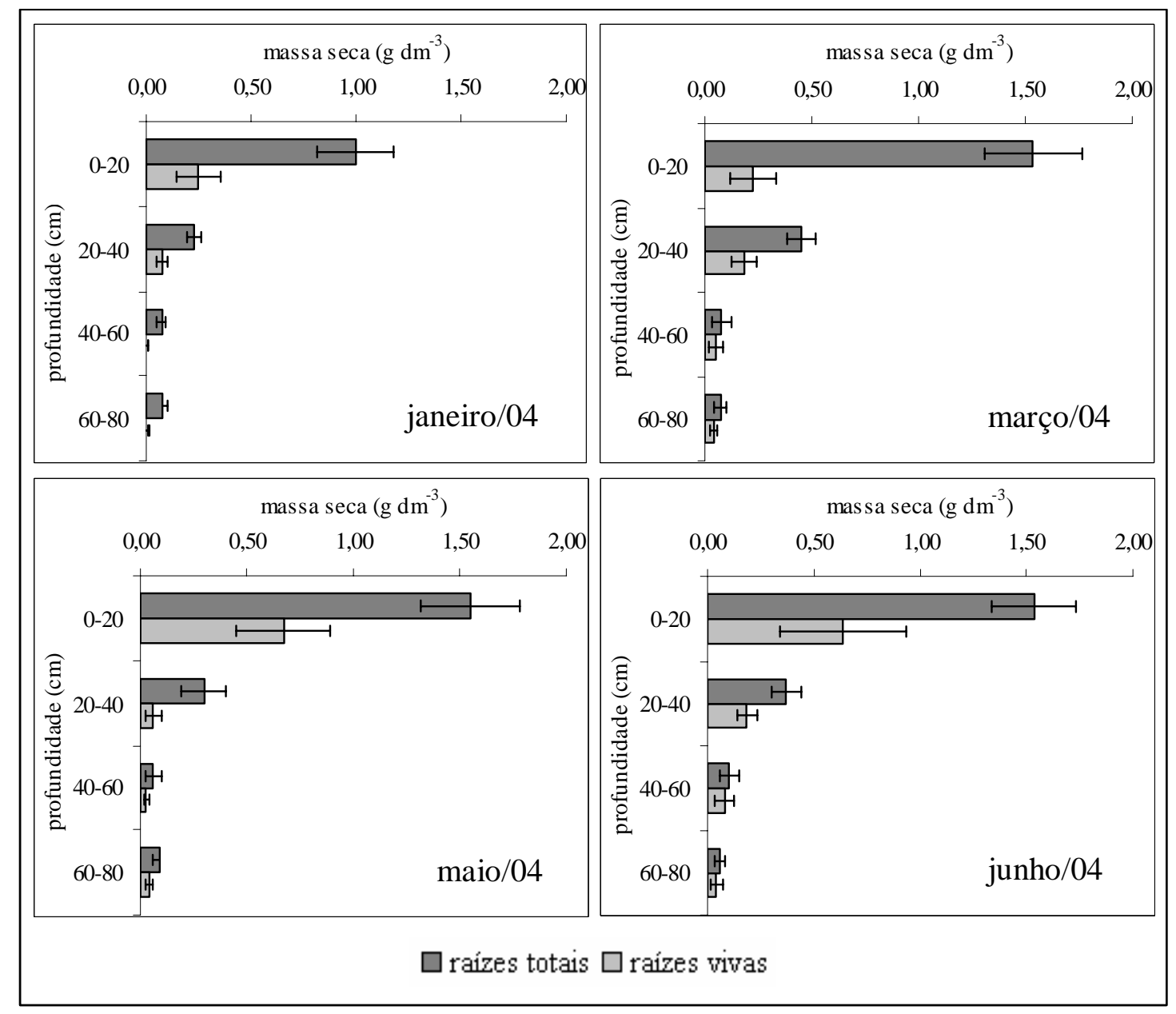

Figura 17 - Raízes totais e raízes vivas $\left(\mathrm{g} \mathrm{dm}^{-3}\right)$ quantificadas pelo método do monólito, no perfil do solo, em janeiro, março, maio e junho de 2004; as barras representam o desvio padrão da média $(n=4)$

Quando se avalia a distribuição porcentual de raízes vivas e do total de raízes (Figura 18), observa-se que os valores são muito próximos, com exceção em março, em que ocorre aumento das raízes vivas em profundidade em relação as totais. A quantidade de raízes vivas aumentou significativamente da primeira para a última amostragem, passando de 0,25 $\mathrm{g} \mathrm{dm}^{-3}$ para 0,64 $\mathrm{g} \mathrm{dm}^{-3}$ nos $20 \mathrm{~cm}$ superficiais, (Figura 17). Na média das profundidades $(0 \mathrm{a} 80 \mathrm{~cm}$ ) esse aumento proporcional foi ainda maior, já que a massa de raízes vivas aumentou de $0,09 \mathrm{~g} \mathrm{dm}^{-3}$ para $0,24 \mathrm{~g} \mathrm{dm}^{-3}$, equivalendo quase ao triplo do valor inicial. 


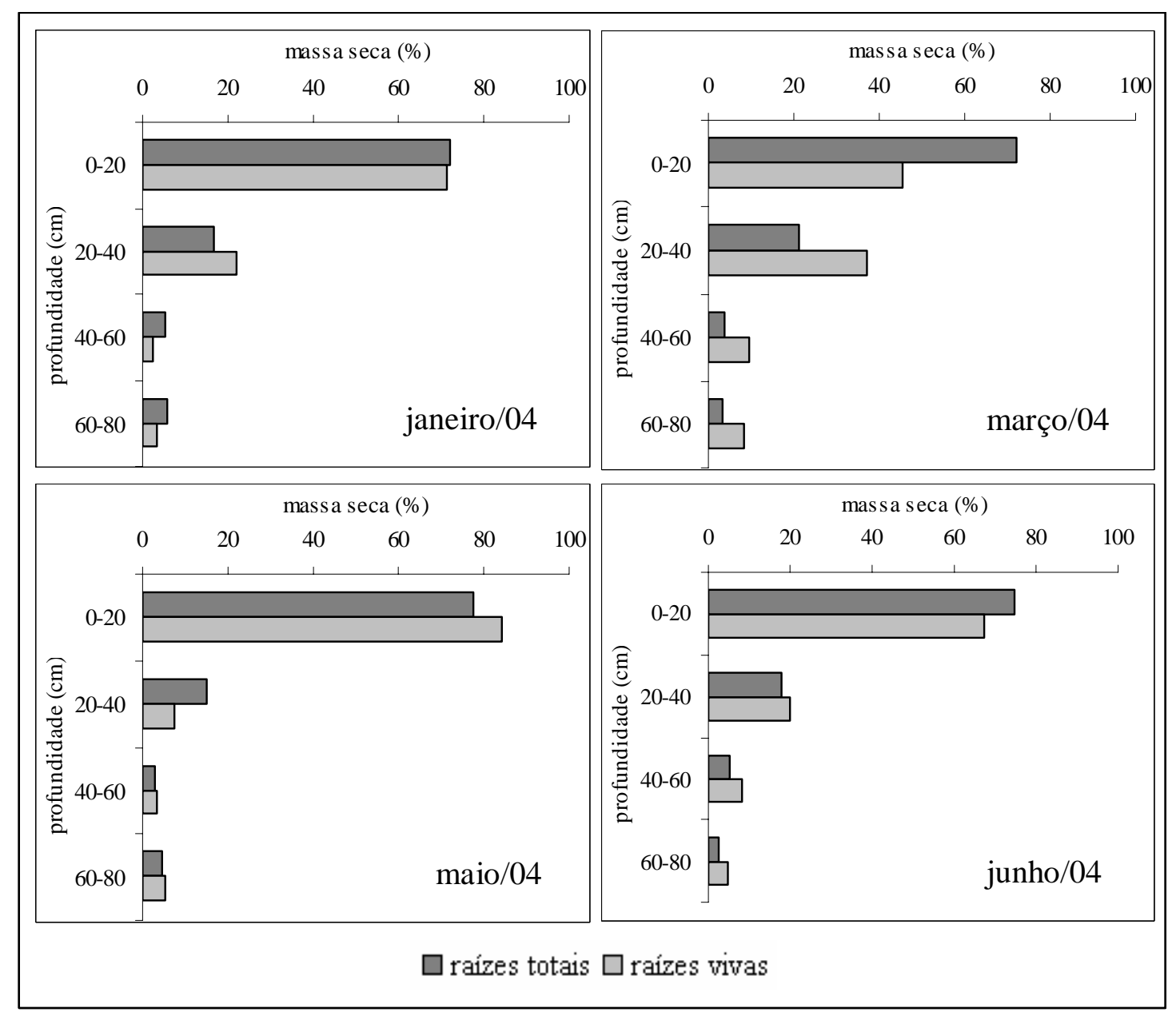

Figura 18 - Distribuição de raízes totais e raízes vivas quantificadas pelo método do monólito no perfil do solo, em janeiro, março, maio e junho de 2004

A porcentagem de raízes vivas em relação ao total, por profundidade de amostragem (Figura 19), aumentou com o tempo, sendo que em janeiro 17\% das raízes totais encontravam-se ativas e em junho essa porcentagem foi de 38\%. O que pode ter ocorrido é que a maior parte das raízes não estava ativa quanto a distribuição do ${ }^{15} \mathrm{~N}$ e, de acordo com as seguintes hipóteses, essa fração não ativa do sistema radicular poderia ser: raízes mortas da linha marcada; raízes de cana-de-açúcar das linhas adjacentes que não foram marcadas com o isótopo $\left({ }^{15} \mathrm{~N}\right)$ e cresceram em direção a linha marcada; raízes que estariam funcionando como órgão de reserva de nutrientes e energia e não estariam translocando compostos assimilados pela parte aérea da planta. 
Faroni \& Trivelin (2004) observaram uma tendência de maior marcação isotópica nas raízes mais superficiais ao solo e próximas a linha de cana-de-açúcar. Os autores atribuíram esse efeito a possível desuniformidade de translocação do ${ }^{15} \mathrm{~N}$ no sistema radicular, bem como a presença de raízes mortas ou raízes de plantas das linhas adjacentes, as quais não foram marcadas com ${ }^{15} \mathrm{~N}$ e apresentavam abundância natural.

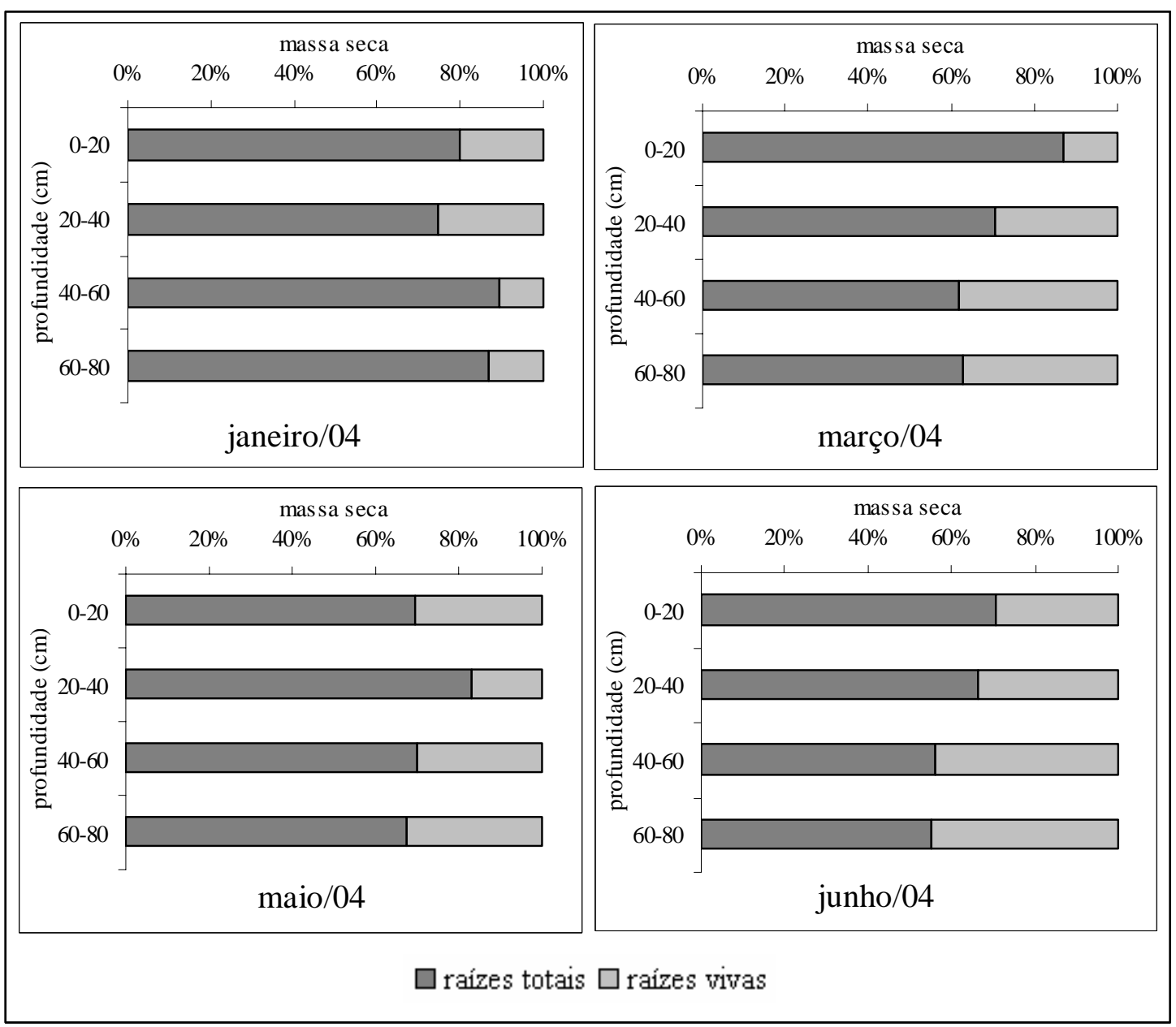

Figura 19 - Distribuição de raízes totais e raízes vivas, por camada de amostragem, quantificadas pelo método do monólito, no perfil do solo, em janeiro, março, maio e junho de 2004 
Outro fato importante que pode ser observado é a maior distribuição porcentual de raízes vivas em profundidade, em média 31\% das raízes totais, enquanto em superfície a média foi de 23\%. Essa tendência de aumento de raízes vivas em profundidade foi observada por Aguiar (1978), no Estado de São Paulo, onde o máximo da formação das raízes aparentemente vivas deu-se: de outubro a maio na profundidade de 0 a $20 \mathrm{~cm}$; de maio a outubro na profundidade de 20 a $40 \mathrm{~cm}$; e de maio a dezembro na profundidade de 40 a 60 cm, em função da faixa de maior disponibilidade de água no solo.

\subsection{Resíduos de raízes metabolicamente ativas no solo}

A Figura 20 representa a massa de raízes vivas, amostradas pelo método do monólito, que passaram pela peneira no processo de sua separação do solo e deixaram de ser contabilizadas na massa de raízes vivas. Como as amostras coletadas por este método passaram por uma peneira de malha de $2 \mathrm{~mm}$, muitas raízes finas e radicelas deixaram de ser coletadas e ficaram no solo. Rizodeposições e descamações radiculares também poderiam fazer parte deste material peneirado, mas como foi curto (96h) o período entre a aplicação da uréia- ${ }^{15} \mathrm{~N}$ e a colheita, essa possibilidade foi desconsiderada.

Os resultados mostram que quanto maior foi a massa de raízes de uma amostra, maior a quantidade de raízes perdidas no peneiramento. Em algumas profundidades a massa residual de raízes vivas foi maior do que a separada pelo peneiramento, principalmente nas amostras das maiores profundidades. No geral, o resíduo de raízes vivas no solo foi da ordem de $46 \%$ do total destas raízes. A contabilização dessas raízes é importante para comparar os métodos, já que a amostra da sonda, neste trabalho, foi analisada integralmente, sem a separação das raízes do solo, estando presentes as raízes finas e radicelas. 


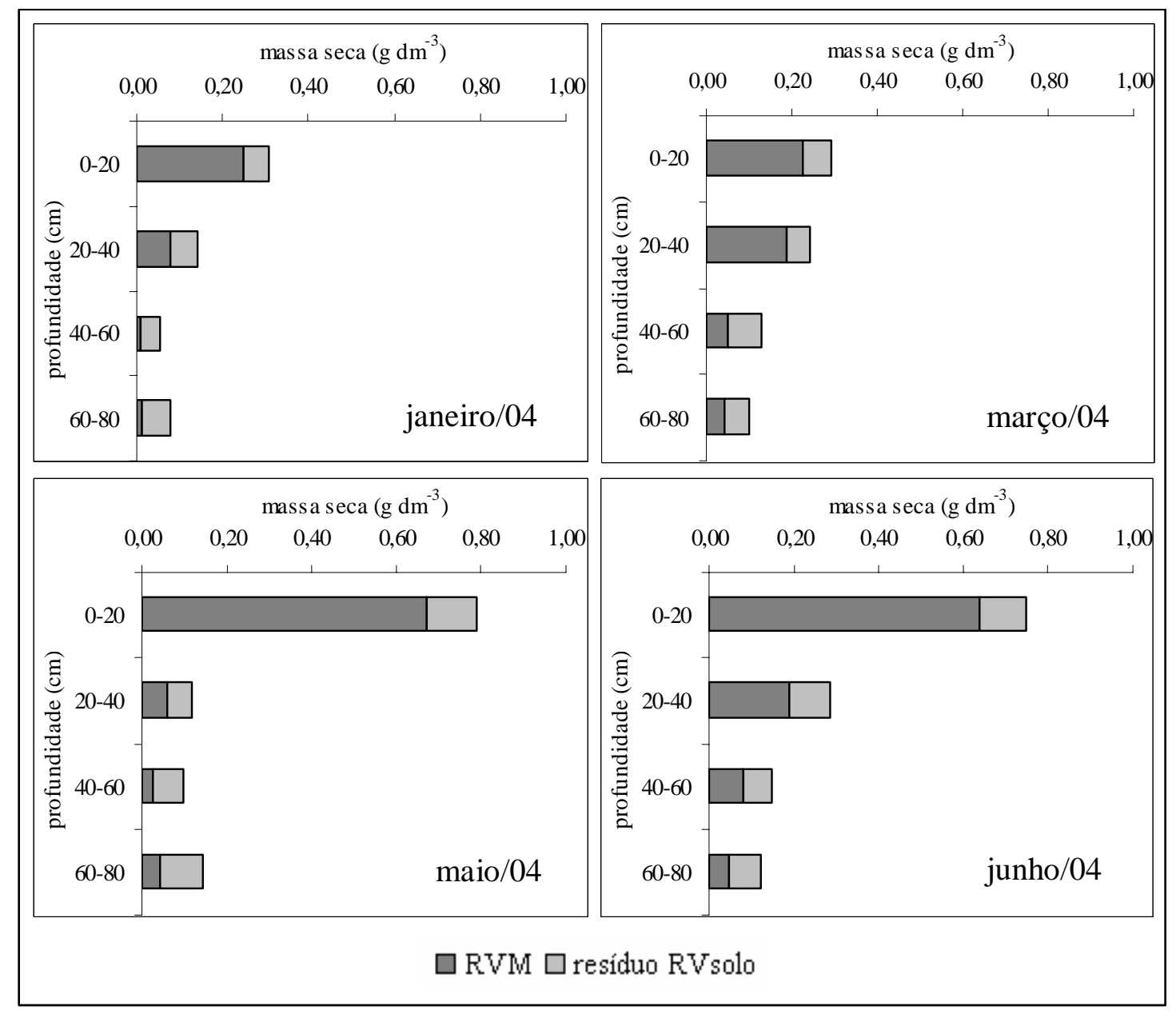

Figura 20 - Massa seca $\left(\mathrm{g} \mathrm{dm}^{-3}\right)$ de raízes vivas do monólito (RVM) e resíduo de raízes vivas no solo (resíduo RVsolo) em diferentes profundidades no perfil, em janeiro, março, maio e junho de 2004

Noordwijk \& Floris (1979) trabalhando com métodos de lavagem e armazenamento de raízes de trigo, observaram que dependendo do método ou do conjunto de métodos utilizados para separar as raízes do solo e armazená-las até o processamento, podem ocorrer perdas de 9 a 43\%. Os autores verificaram ainda, perdas da ordem de $17 \%$ da massa de raízes totais utilizando a mesma metodologia empregada neste experimento.

Na maioria dos trabalhos que tratam de sistemas radiculares não é dada muita importância a essas possíveis perdas de raízes de pequeno diâmetro no momento da 
separação do solo. No entanto, quanto menor o diâmetro da raiz, maior sua área específica e contato com a solução do solo para a absorção de água e nutrientes. São nas raízes finas e radicelas que ocorrem as infecções por micorrizas, que aumentam a área de absorção, além de elevar a disponibilidade de alguns nutrientes (Anghinoni \& Meurer, 1999; Rheinheimer \& Anghinoni, 2001).

\subsection{Análise comparativa dos métodos de amostragem do sistema radicular para massa seca de raízes metabolicamente ativas}

Comparando-se os valores amostrados de raízes ativas (vivas), determinadas por diluição isotópica, pelos métodos da sonda e do monólito (Figura 21), observa-se que somente na camada superficial não houve diferença. Para todas as outras profundidades ocorreu diferença significativa, sendo que o método da sonda superestimou as amostragens em relação ao método do monólito.

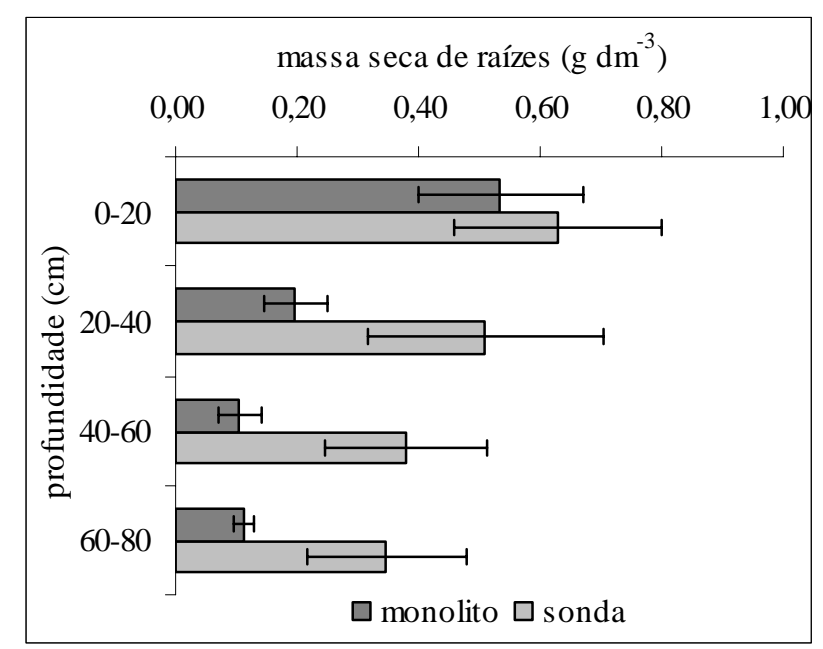

Figura 21 - Massa seca de raízes vivas $\left(\mathrm{g} \mathrm{dm}^{-3}\right)$ pelos dois métodos de amostragem: monólito (mais resíduo de raízes vivas no solo) e sonda, para avaliação da distribuição de raízes vivas no perfil do solo, na média das quatro épocas de amostragem; as barras representam o desvio padrão da média $(n=4)$ 
Com relação às épocas de amostragem, apenas de maio a junho ocorreu aumento da massa do sistema radicular no método do monólito, na média de todo o perfil do solo (Tabela 5). Os métodos, considerando as médias gerais, mostraram-se equivalentes apenas em junho, tendo a sonda, nos outros meses, superestimado a massa do sistema radicular em relação ao monólito.

Analisando-se separadamente as épocas de amostragem (Figura 22), tem-se que em $50 \%$ dos locais ou pontos de amostragem não ocorreram diferenças. Nos $20 \mathrm{~cm}$ superficiais, onde localizou-se 75\% do sistema radicular, os métodos não diferiram em nenhuma época, com valores bem próximos. No entanto, em profundidade, a variação foi maior sendo que os métodos não diferiram em maio, de 20 a 40 e de 60 a $80 \mathrm{~cm}$, e em junho, de 20 a 40 e de 40 a $60 \mathrm{~cm}$.

Tabela 5. Massa seca de raízes vivas $\left(\mathrm{g} \mathrm{dm}^{-3}\right)$ de todo perfil do solo, de entrelinha a entrelinha, amostradas pelos métodos do monólito e da sonda, em quatro épocas de amostragens $(\mathrm{n}=16)$

\begin{tabular}{ccc}
\hline Época de amostragem & Monólito & Sonda \\
\hline Janeiro/2004 & $0,15 \mathrm{Bb}$ & $0,48 \mathrm{Aa}$ \\
Março/2004 $\mathrm{gm}^{-3}$ & $0,45 \mathrm{Aa}$ \\
Maio/2004 & $0,19 \mathrm{Bb}$ & $0,46 \mathrm{Aa}$ \\
Junho/2004 & $0,29 \mathrm{Bb}$ & $0,47 \mathrm{Aa}$ \\
Média & $0,33 \mathrm{Aa}$ & $0,47 \mathrm{~A}$ \\
CV (\%) & $0,24 \mathrm{~B}$ & 2,8 \\
\hline
\end{tabular}

Médias seguidas de mesma letra não diferem entre si pelo teste de Tukey a 5\% de probabilidade, sendo que as letras maiúsculas comparam médias nas linhas e as minúsculas nas colunas. 


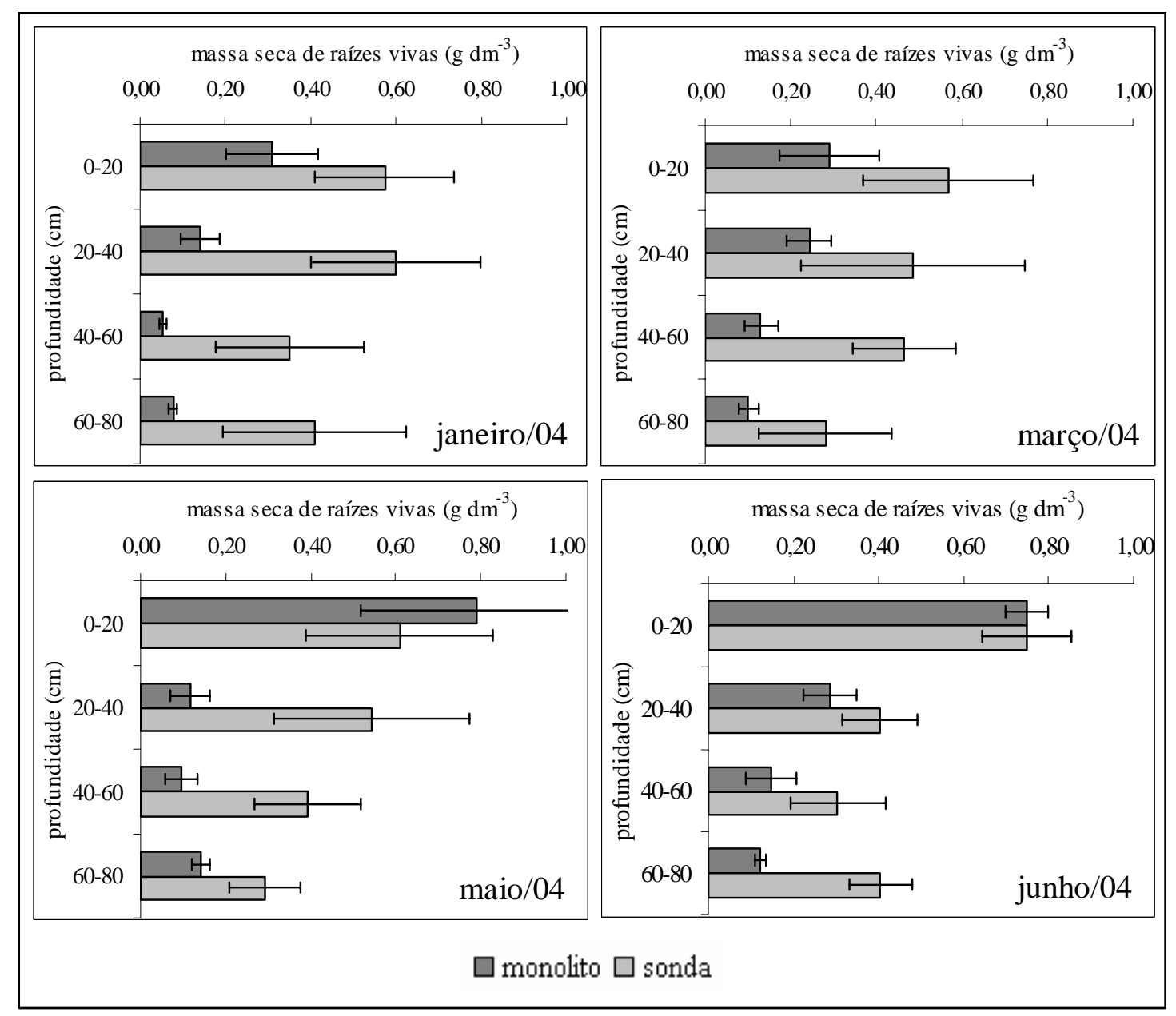

Figura 22 - Massa seca de raízes vivas $\left(\mathrm{g} \mathrm{dm}^{-3}\right.$ ) obtidas pelos métodos de amostragem: monólito (mais resíduos de raízes vivas no solo) e sonda, no perfil do solo, em janeiro, março, maio e junho de 2004; as barras representam o desvio padrão da média $(\mathrm{n}=4)$

Vasconcelos (2002b) verificou que houve desenvolvimento acumulativo do sistema radicular da cana-de-açúcar com o tempo, e ressaltou que não foi possível constatar a renovação do mesmo a cada ciclo da cultura. O crescimento de raízes em plantas perenes, segundo Klepper (1991), ocorre por fluxos de atividade com padrões de distribuição dos fotoassimilados variando com a estação do ano. Se faz importante, então, compreender estes fluxos de atividade e emissão de novas raízes da cana-de- 
açúcar, e como demonstrado neste trabalho a técnica da diluição isotópica com ${ }^{15} \mathrm{~N}$ pode ser utilizada em estudos dessa natureza.

Entretanto, a escassez ou inexistência de trabalhos com avaliação da distribuição e/ou a quantificação de raízes vivas ou ativas no solo, particularmente para a cana-deaçúcar, dificulta as comparações de resultados e discussões em relação aos dados e informações apresentados neste trabalho. Poucas são as metodologias para o estudo e separação de raízes vivas e mortas, sendo estas, na maioria, com o uso de corantes celulares como a Fuccina Básica, usada apenas na análise qualitativa, e o Tetrazolium, que pode ser usado na análise quantitativa, mas de forma indireta (Steponkus \& Lanphear, 1967; Ruf \& Brunner, 2003). Em adendo, essas metodologias são complicadas e trabalhosas, além da necessidade de serem realizadas imediatamente após a amostragem das raízes, enquanto estas estão metabolicamente ativas. No caso da

utilização da metodologia de diluição isotópica de ${ }^{15} \mathrm{~N}$, o material pode ser processado e armazenado sem a necessidade de protocolos ou cuidados especiais.

O estudo do sistema radicular, não somente como um todo, englobando raízes vivas e mortas, mas também de seus fluxos de atividade e emissão de novas raízes, de um ciclo para outro, com a identificação de raízes metabolicamente ativas, sua massa e distribuição, pode contribuir para o melhor entendimento das relações da planta com o ambiente de produção e, provavelmente, redirecionar o manejo da cultura, visando o uso de práticas agrícolas mais eficientes e sustentáveis, que preservem o ambiente e economizem os recursos naturais, alcançando, em última instância, maior produtividade e longevidade dos canaviais.

\subsection{Considerações finais}

A maioria dos trabalhos encontrados na literatura até o momento, que envolvem as várias técnicas existentes para o estudo de raízes, principalmente para culturas perenes, não fazem distinção entre raízes metabolicamente ativas e mortas, nem menção aos os fluxos de emissão de novas raízes a cada ciclo do vegetal, o que trata-se de um 
contra-senso já que são as raízes vivas as responsáveis pela relação solo-planta, principalmente na absorção de água e nutrientes.

O objetivo central deste trabalho foi o de desenvolver um método de amostragem a fim de distinguir, em uma massa total de raízes, as raízes vivas de mortas com o uso do marcador isotópico ${ }^{15} \mathrm{~N}$. Com este trabalho, os resultados dão indicativos consistentes da exeqüibilidade da técnica. A quantidade de dados gerados por este experimento permitirá várias inferências além das aqui apresentadas. No entanto, como todo novo método, a falta de trabalhos na mesma linha de pesquisa dificulta comparações e avaliações. Os poucos trabalhos que serviram de base para este, estudos como os que avaliam métodos de marcação de plantas com ${ }^{15} \mathrm{~N}$ e os que estudam o nitrogênio do sistema radicular das plantas (“below ground nitrogen” - BGN), são realizados na maioria com plantas forrageiras e leguminosas, não voltados ao estudo do sistema radicular, mas sim do ciclo do $\mathrm{N}$ no solo.

Sendo assim, espera-se que essa técnica possa ser usada em outros estudos, não só com a cultura da cana-de-açúcar, mas também com outras espécies, e que também possa ser desmistificada a idéia de que estudos isotópicos são complicados e onerosos, e que estes possam ser mais usados, não só para avaliar o crescimento radicular, mas também as reservas de $\mathrm{N}$, principalmente em plantas que rebrotam às custas de reservas do sistema radicular após o corte, como é o caso da cana-de-açúcar. 


\section{CONCLUSÕES}

Com base nos resultados apresentados e nas condições em que foi realizado o trabalho conclui-se que:

a) o método da diluição isotópica com ${ }^{15} \mathrm{~N}$ possibilitou avaliar a massa de raízes metabolicamente ativas (vivas) de cana-de-açúcar e sua distribuição no solo;

b) o método de amostragem com a sonda amostradora de raízes foi viável em comparação com a amostragem do monólito em trincheira, para quantificação de raízes: nas profundidades de 0 a 20, 20 a 40 e 60 a $80 \mathrm{~cm}$ do perfil do solo para raízes totais, e nos $20 \mathrm{~cm}$ superficiais do solo para raízes vivas, onde a massa de raízes é maior;

c) ocorreu morte do sistema radicular concomitantemente ao desenvolvimento de novas raízes, o que fica evidenciado pelo crescimento proporcional da massa de raízes totais e vivas;

d) a distribuição de raízes vivas, em relação ao total do sistema radicular de cada camada do solo, foi proporcionalmente maior nas camadas mais profundas;

e) a determinação da massa de raízes vivas que permaneceu junto com o solo após peneiramento foi de fundamental importância na contabilização da massa de raízes vivas total amostrada pelo método do monólito;

f) o sistema radicular da cana de açúcar distribuiu-se superficialmente e próximo a linha de plantio. 
ANEXOS 
Anexo A

Tabela 6. Abundância em ${ }^{15} \mathrm{~N}$ dos compartimentos estudados, nos diferentes locais e épocas de amostragem

\begin{tabular}{|c|c|c|c|c|c|}
\hline Compartimento & Local & Janeiro & Março & Maio & Junho \\
\hline & & \multicolumn{4}{|c|}{$\%{ }^{15} \mathrm{~N}$} \\
\hline Parte Aérea & Parcela Central & 1,081 & 0,840 & 0,956 & 2,706 \\
\hline \multicolumn{6}{|l|}{ Padrão Raiz } \\
\hline & $0-20 \mathrm{~cm}$ & 1,237 & 1,662 & 1,214 & 0,483 \\
\hline & $20-40 \mathrm{~cm}$ & 0,624 & 0,675 & 0,569 & 0,428 \\
\hline & $40-60 \mathrm{~cm}$ & 0,583 & 0,399 & 0,417 & 0,402 \\
\hline & $60-80 \mathrm{~cm}$ & 0,546 & 0,388 & 0,420 & 0,384 \\
\hline \multicolumn{6}{|l|}{ Raízes } \\
\hline & $0-20 \mathrm{~cm}$ & 0,516 & 0,497 & 0,529 & 0,381 \\
\hline & $20-40 \mathrm{~cm}$ & 0,410 & 0,431 & 0,412 & 0,378 \\
\hline & $40-60 \mathrm{~cm}$ & 0,400 & 0,379 & 0,378 & 0,379 \\
\hline & $60-80 \mathrm{~cm}$ & 0,390 & 0,376 & 0,386 & 0,377 \\
\hline \multicolumn{6}{|l|}{ Rizomas } \\
\hline & Parcela Central & - & 1,130 & 1,180 & - \\
\hline \multicolumn{6}{|l|}{ Solo + Raízes } \\
\hline & $0-20 \mathrm{~cm}$ & 0,385 & 0,393 & 0,384 & 0,374 \\
\hline & $20-40 \mathrm{~cm}$ & 0,375 & 0,374 & 0,372 & 0,371 \\
\hline & $40-60 \mathrm{~cm}$ & 0,374 & 0,371 & 0,371 & 0,371 \\
\hline & $60-80 \mathrm{~cm}$ & 0,371 & 0,369 & 0,370 & 0,370 \\
\hline \multicolumn{6}{|l|}{ Padrão Solo } \\
\hline & $0-20 \mathrm{~cm}$ & \multicolumn{4}{|c|}{0,371} \\
\hline & $20-40 \mathrm{~cm}$ & \multicolumn{4}{|c|}{0,370} \\
\hline & $40-60 \mathrm{~cm}$ & \multicolumn{4}{|c|}{0,370} \\
\hline & $60-80 \mathrm{~cm}$ & \multicolumn{4}{|c|}{0,369} \\
\hline \multicolumn{6}{|l|}{ Solo } \\
\hline & $0-20 \mathrm{~cm}$ & 0,373 & 0,373 & 0,374 & 0,372 \\
\hline & $20-40 \mathrm{~cm}$ & 0,371 & 0,371 & 0,371 & 0,371 \\
\hline & $40-60 \mathrm{~cm}$ & 0,371 & 0,371 & 0,371 & 0,371 \\
\hline & $60-80 \mathrm{~cm}$ & 0,370 & 0,369 & 0,369 & 0,369 \\
\hline
\end{tabular}


Anexo B

Tabela 7. Teores de N (\%) dos compartimentos estudados, nos diferentes locais e épocas de amostragem

\begin{tabular}{|c|c|c|c|c|c|}
\hline Compartimento & Local & Janeiro & Março & Maio & Junho \\
\hline & & \multicolumn{4}{|c|}{$\% \mathrm{~N}$} \\
\hline Parte Aérea & Parcela Central & 0,81 & 0,37 & 0,36 & 0,81 \\
\hline \multicolumn{6}{|l|}{ Padrão Raiz } \\
\hline & $0-20 \mathrm{~cm}$ & 0,86 & 0,70 & 0,68 & 0,62 \\
\hline & $20-40 \mathrm{~cm}$ & 0,76 & 0,46 & 0,56 & 0,59 \\
\hline & $40-60 \mathrm{~cm}$ & 0,76 & 0,46 & 0,53 & 0,43 \\
\hline & $60-80 \mathrm{~cm}$ & 0,78 & 0,44 & 0,49 & 0,48 \\
\hline \multicolumn{6}{|l|}{ Raízes } \\
\hline & $0-20 \mathrm{~cm}$ & 0,79 & 0,61 & 0,69 & 0,77 \\
\hline & $20-40 \mathrm{~cm}$ & 0,73 & 0,70 & 0,57 & 0,67 \\
\hline & $40-60 \mathrm{~cm}$ & 0,67 & 0,55 & 0,52 & 0,59 \\
\hline & $60-80 \mathrm{~cm}$ & 0,58 & 0,52 & 0,46 & 0,54 \\
\hline \multicolumn{6}{|l|}{ Rizomas } \\
\hline & Parcela Central & - & 0,54 & 0,98 & - \\
\hline \multicolumn{6}{|l|}{ Solo + Raízes } \\
\hline & $0-20 \mathrm{~cm}$ & 0,06 & 0,07 & 0,05 & 0,05 \\
\hline & $20-40 \mathrm{~cm}$ & 0,04 & 0,07 & 0,04 & 0,03 \\
\hline & $40-60 \mathrm{~cm}$ & 0,03 & 0,06 & 0,03 & 0,03 \\
\hline & $60-80 \mathrm{~cm}$ & 0,02 & 0,05 & 0,02 & 0,02 \\
\hline \multicolumn{6}{|l|}{ Padrão Solo } \\
\hline & $0-20 \mathrm{~cm}$ & & & & \\
\hline & $20-40 \mathrm{~cm}$ & & & & \\
\hline & $40-60 \mathrm{~cm}$ & & & & \\
\hline & $60-80 \mathrm{~cm}$ & & & & \\
\hline \multicolumn{6}{|l|}{ Solo } \\
\hline & $0-20 \mathrm{~cm}$ & 0,04 & 0,08 & 0,05 & 0,04 \\
\hline & $20-40 \mathrm{~cm}$ & 0,04 & 0,07 & 0,04 & 0,03 \\
\hline & $40-60 \mathrm{~cm}$ & 0,03 & 0,08 & 0,03 & 0,03 \\
\hline & $60-80 \mathrm{~cm}$ & 0,02 & 0,05 & 0,02 & 0,02 \\
\hline
\end{tabular}


Anexo C

Tabela 8. Massa seca de raízes totais $\left(\mathrm{g} \mathrm{dm}^{-3}\right)$ pelos dois métodos de amostragem (monólito e sonda) e por local, para as quatro épocas de amostragem

\begin{tabular}{|c|c|c|c|c|c|c|}
\hline \multicolumn{2}{|c|}{ Local } & Método & Janeiro & Março & Maio & Junho \\
\hline & & & \multicolumn{4}{|c|}{ g. $\mathrm{dm}^{-3}$} \\
\hline \multirow[t]{2}{*}{$0-20$} & Linha & Monólito & 2,02 & 2,59 & 3,24 & 3,68 \\
\hline & & Sonda & 2,41 & 4,38 & 5,26 & 6,41 \\
\hline \multirow[t]{2}{*}{$0-20$} & $14-42 \mathrm{~cm}$ & Monólito & 0,65 & 1,06 & 0,68 & 0,61 \\
\hline & & Sonda & 0,68 & 2,42 & 1,73 & 1,22 \\
\hline \multirow[t]{2}{*}{$0-20$} & $42-70 \mathrm{~cm}$ & Monólito & 0,32 & 0,95 & 0,73 & 0,32 \\
\hline & & Sonda & 0,61 & 1,92 & 1,04 & 1,04 \\
\hline \multirow[t]{2}{*}{$20-40$} & Linha & Monólito & 0,42 & 0,88 & 0,59 & 0,64 \\
\hline & & Sonda & 1,88 & 2,62 & 1,51 & 1,27 \\
\hline \multirow[t]{2}{*}{$20-40$} & $14-42 \mathrm{~cm}$ & Monólito & 0,16 & 0,29 & 0,19 & 0,37 \\
\hline & & Sonda & 0,11 & 1,13 & 0,65 & 0,68 \\
\hline \multirow[t]{2}{*}{$20-40$} & $42-70 \mathrm{~cm}$ & Monólito & 0,11 & 0,18 & 0,12 & 0,10 \\
\hline & & Sonda & 0,06 & 0,78 & 0,37 & 0,26 \\
\hline \multirow[t]{2}{*}{$40-60$} & Linha & Monólito & 0,13 & 0,14 & 0,12 & 0,24 \\
\hline & & Sonda & 0,36 & 0,62 & 0,23 & 0,40 \\
\hline \multirow[t]{2}{*}{$40-60$} & $14-42 \mathrm{~cm}$ & Monólito & 0,04 & 0,06 & 0,02 & 0,02 \\
\hline & & Sonda & 0,19 & 0,66 & 0,11 & 0,85 \\
\hline \multirow[t]{2}{*}{$40-60$} & $42-70 \mathrm{~cm}$ & Monólito & 0,05 & 0,04 & 0,04 & 0,05 \\
\hline & & Sonda & 0,03 & 0,16 & 0,07 & 0,29 \\
\hline \multirow[t]{2}{*}{$60-80$} & Linha & Monólito & 0,12 & 0,10 & 0,14 & 0,06 \\
\hline & & Sonda & 0,57 & 0,12 & 0,11 & 0,11 \\
\hline \multirow[t]{2}{*}{$60-80$} & $14-42 \mathrm{~cm}$ & Monólito & 0,07 & 0,09 & 0,07 & 0,06 \\
\hline & & Sonda & 0,12 & 0,15 & 0,14 & 0,33 \\
\hline \multirow[t]{2}{*}{$60-80$} & $42-70 \mathrm{~cm}$ & Monólito & 0,06 & 0,03 & 0,07 & 0,05 \\
\hline & & Sonda & 0,05 & 0,02 & 0,04 & 0,11 \\
\hline
\end{tabular}


Anexo D

Tabela 9. Massa seca de raízes vivas $\left(\mathrm{g} \mathrm{dm}^{-3}\right.$ ) pelos dois métodos de amostragem (monólito e sonda) e por local, para as quatro épocas de amostragem

\begin{tabular}{|c|c|c|c|c|c|c|}
\hline \multicolumn{2}{|c|}{ Local } & Método & Janeiro & Março & Maio & Junho \\
\hline & & & \multicolumn{4}{|c|}{$\mathrm{g} \mathrm{dm}^{-3}$} \\
\hline \multirow[t]{2}{*}{$0-20$} & Linha & Monólito & 0,73 & 0,60 & 1,96 & 1,85 \\
\hline & & Sonda & 1,49 & 1,02 & 0,73 & 0,95 \\
\hline \multirow[t]{2}{*}{$0-20$} & $14-42 \mathrm{~cm}$ & Monólito & 0,14 & 0,23 & 0,32 & 0,19 \\
\hline & & Sonda & 0,19 & 0,38 & 0,71 & 0,67 \\
\hline \multirow[t]{2}{*}{$0-20$} & $42-70 \mathrm{~cm}$ & Monólito & 0,06 & 0,05 & 0,09 & 0,20 \\
\hline & & Sonda & 0,04 & 0,35 & 0,39 & 0,62 \\
\hline \multirow[t]{2}{*}{$20-40$} & Linha & Monólito & 0,25 & 0,50 & 0,08 & 0,58 \\
\hline & & Sonda & 1,34 & 0,65 & 0,66 & 0,44 \\
\hline \multirow[t]{2}{*}{$20-40$} & $14-42 \mathrm{~cm}$ & Monólito & 0,09 & 0,08 & 0,16 & 0,12 \\
\hline & & Sonda & 0,28 & 0,37 & 0,45 & 0,36 \\
\hline \multirow[t]{2}{*}{$20-40$} & $42-70 \mathrm{~cm}$ & Monólito & 0,09 & 0,15 & 0,11 & 0,16 \\
\hline & & Sonda & 0,18 & 0,44 & 0,52 & 0,41 \\
\hline \multirow{2}{*}{$40-60$} & Linha & Monólito & 0,04 & 0,17 & 0,11 & 0,25 \\
\hline & & Sonda & 0,26 & 0,72 & 0,61 & 0,40 \\
\hline \multirow[t]{2}{*}{$40-60$} & $14-42 \mathrm{~cm}$ & Monólito & 0,05 & 0,08 & 0,09 & 0,08 \\
\hline & & Sonda & 0,31 & 0,52 & 0,18 & 0,21 \\
\hline \multirow[t]{2}{*}{$40-60$} & $42-70 \mathrm{~cm}$ & Monólito & 0,06 & 0,14 & 0,08 & 0,11 \\
\hline & & Sonda & 0,48 & 0,16 & 0,40 & 0,30 \\
\hline \multirow[t]{2}{*}{$60-80$} & Linha & Monólito & 0,09 & 0,12 & 0,16 & 0,14 \\
\hline & & Sonda & 0,21 & 0,17 & 0,37 & 0,41 \\
\hline \multirow[t]{2}{*}{$60-80$} & $14-42 \mathrm{~cm}$ & Monólito & 0,06 & 0,14 & 0,16 & 0,12 \\
\hline & & Sonda & 0,47 & 0,44 & 0,19 & 0,44 \\
\hline \multirow[t]{2}{*}{$60-80$} & $42-70 \mathrm{~cm}$ & Monólito & 0,08 & 0,04 & 0,11 & 0,11 \\
\hline & & Sonda & 0,55 & 0,23 & 0,33 & 0,37 \\
\hline
\end{tabular}




\section{REFERÊNCIAS BIBLIOGRÁFICAS}

AGUIAR, S.F. Observações sobre sistema radicular de cana planta (Saccharum spp.) Jaboticabal, Faculdade de Ciências Agrária e Veterinárias - Universidade Estadual Paulista, 1978. 24p.

ALEXANDER, A.G. Sugar cane physiology: a comprehensive study of Saccharum souce-to-link system. Amsterdam: Elsevier, 1973. 752p.

ALVAREZ, I.A.; CASTRO, P.R.C.; NOGUEIRA, M.C.S. Crescimento de raízes de cana crua e cana queimada em dois ciclos. Scientia Agrícola, , v.57, n.4, p.653-659, 2000.

AMBROSANO, E.J.; TRIVELIN, P.C.O.; CANTARELLA, H.; ROSSETTO, R.; MURAOKA, T.; BENDASSOLLI, J.A.; AMBROSANO, G.M.B.; TAMISO, L.G.; VIEIRA, F.C.; PRADA NETO, I. Nitrogen-15 labeling of Crotalaria juncea green manure. Scientia Agricola, v.60, n.1, p.181-184, 2003.

ANGHINONI, I; MEURER, E.J. Eficiência de absorção de nutrientes pelas raízes. In: WORKSHOP SOBRE SISTEMA RADICULAR: METODOLOGIAS E ESTUDOS DE CASO. Aracajú, 1999. Anais Embrapa Tabuleiros Costeiros, 1999. p.57-87.

BACCHI, O.O.S. Botânica da cana-de-açúcar. In: ORLANDO FILHO, J. Nutrição e adubação da cana-de-açúcar no Brasil. Piracicaba: IAA/Planalsucar, 1983. cap.2, p.24-37. 
BALL-COELHO, B.; SAMPAIO, E.V.S.B.; TIESSEN, H.; STEWART, J.W.B. Root dynamic in plant ratoon crops of sugar cane. Plant and Soil, v.142, p.297-305, 1992.

BARRIE, A.; PROSSER, S.J. Automated analysis of ligth-element stable isotopes by isotope ratio mass spctrometry. In: BOUTTON, T.W., YAMSAHI, S. (Ed.). Mass spectrometry of soils. New York: Marcel Dekker., 1996. p.1-46.

BLACKBURN, F. Sugarcane. New York: Longman, 1984. 414p.

BRAUNACK, M.V.; PEATEY, T.C. Changes in soil physical properties after one pass of a sugarcane haulout unit. Australian Journal Experimental Agriculture, v.39, p.733-742, 1999.

CÂMARA, G.M.S. Ecofisiologia da cultura de cana-de-açúcar. In: CÂMARA, G.M.S.; OLIVEIRA, E.A.M. (Ed.). Produção de cana-de-açúcar. Piracicaba: ESALQ/FEALQ, 1993. p209-225.

CAMARGO, M.B.P.; CAMARGO, A.P. Representação gráfica informatizada do extrato do balanço hídrico de Thornthwaite \& Mather. Bragantia, v.52, p.169-172, 1993.

CAMARGO, P.B. Dinâmica do nitrogênio dos fertilizantes uréia $\left({ }^{15} \mathrm{~N}\right)$ e aquamônia $\left({ }^{15} \mathrm{~N}\right)$ incorporados ao solo na cultura de cana-de-açúcar. Piracicaba, 1989. 104p. Dissertação (Mestrado) - Escola Superior de Agricultura “Luiz de Queiroz”, Universidade de São Paulo.

CASAGRANDE, A.A. Tópicos de morfologia e fisiologia da cana-de-açúcar. Jaboticabal: FUNEP, 1991. 157p. 
CASTRO, P.R.C.; KLUGE, R.A. Ecofisiologia de culturas extrativas: cana-deaçúcar; seringueira; coqueiro; dendezeiro e oliveira. Cosmópolis: Stoller do Brasil, 2001. 138p.

DILLEWIJN, C. van. Botany of sugarcane. Waltham: Chronica Botanica, 1952. 371p.

EMPRESA BRASILEIRA DE PESQUISA AGROPECUÁRIA. Centro Nacional de Pesquisa de Solos. Sistema brasileiro de classificação de solos. Rio de Janeiro, 1999. 412p.

EPSTEIN, E. Nutrição mineral das plantas: princípios e perspectivas. Trad. de E. Malavolta. São Paulo: EDUSP; Rio de Janeiro: Livros Técnicos e Científicos, 1975. 341p.

FANTE JUNIOR, L.; REICHARDT, K.; JORGE, L.A.C.; BACCHI, O.O.S. Distribuição do sistema radicular de uma cultura de aveia forrageira. Scientia Agricola, v.56, no.4, supl, p.1091-1100, 1999.

FARONI, C.E.; TRIVELIN, P.C.O. Avaliação do sistema radicular de cana-de-açúcar pela técnica da diluição isotópica com ${ }^{15} \mathrm{~N}$. Compact Disc In: FERTIBIO 2004. Lages: SBCS/UDESC, 2004.

FERNANDES, J.; RIPOLI, T.C.; MILLAN, M. A compactação do solo e a brotação das soqueiras. Álcool \& Açúcar, v.3, n.12, p.12-17, 1983.

FURLANI, P.R. Toxidade de alumínio e toxidez em plantas. In: RAIJ, B. van; BATAGLiA, O.C.; SILVA, N.M. Acidez e calagem no Brasil. Campinas: Sociedade Brasileira de Ciência do Solo, 1983. p.78-86. 
HAVLIN J.D.; BEATON J.D.; TISDALE L.T.; NELSON W.L. Soil fertility and fertilizers: an introduction to soil management. 6. ed. New York: Prentice Hall, 1999. 499p.

HUMBERT, R.P. Fertilization by aircraft in the Hawaiian sugar industry. The Hawaiian Planter's Record, v.55, n.4, p.301-311, 1960.

HUMBERT, R.P. The growing of sugarcane. Amsterdam: Elsevier, 1968. 779p.

INFORZATO, R.; ALVAREZ, R. Distribuição do sistema radicular da cana-de-açúcar var. Co. 290, em solo tipo terra-roxa-legítima. Bragantia, v.16, n.1, p.1-13, 1957.

JANSEN, H.H.; BRUINSMA, Y. Methodology for the quantification of root and rhizosphere nitrogen dynamics by exposure of shoots to $15 \mathrm{~N}$-labelled ammonia. Soil Biology \& Biochemistry, v.21, p.189-196, 1989.

JENSEN, J.H. Some studies of root habits of sugar cane in Cuba. Yonkers, N.Y.: Tropical Plant Research Foundation, 1951. 37p.

KIRKHAM, M. B. Soil-oxygen and plant-root interaction: an electrical analog study. In: DIEST, A. van, (ed). Plant and soil: interfaces and interactions. Wageningen, Martinius Nijhoff Publishers, 1987. p.11-19.

KLEPPER, B. Root-shoot relationships. In: WAISEL, Y.; ESHEL, A.; KADAFKI, V. Plant roots: the hidden half. New York: Marcel Decker, 1991. p.265-286.

KÖPKE, V. Methods for studying root growth. In: SYMPOSIUM ON THE SOIL/ROOT SYSTEM, Londrina, 1980. Proceedings Londrina: Fundação Instituto Agronômico do Paraná, 1981. p.303-318. 
KORNDÖRFER, G.H.; PRIMAVESI, O.; DEUBER, R. Crescimento e distribuição do sistema radicular da cana-de-açúcar em solo LVA. Piracicaba: Coopersucar. 1989, n.47, p.32-36. (Boletim Técnico 47)

KÜCKE, M.; SCHMID, H.; SPIESS, A. A comparison of four methods for measuring roots in field crops in three contrasting soils. Plant Soil, v.172, p.63-71, 1955.

LANDELL, M.G.A.; PRADO, H.; VASCONCELOS, A.C.M.; VIEIRA.; S.R.; XAVIER, M.A. Histórico sobre os critérios pedológicos para qualificação de ambientes de produção da cana-de-açúcar no Estado de São Paulo, Brasil. In: II JORNADAS SOBRE AGRICULTURA DE PRECISIÓN, A Corunã, 2004. Proceedings. A Corunã: Faculdad de Ciencias, Campus de A. Zapateira, 2004, v.1, p.48-50.

LEE, H.A. The distribution of the roots of sugar cane in the soil in the Hawaiian Islands. Plant Physiology, v.1, p.363-378, 1926.

LUXMOORE, R.L.; STOLZY, L.H. Modeling belowground processes of roots, the rizosphere, and the soil communities. In: WISIOL, K.; HESKETH, J.D. Plant growth modeling for resource management: quantifying plant processes. Вoca Raton: CRC Press, 1987. v.2, p.129-153.

MACHADO, E.C. Fisiologia de produção de cana-de-açúcar. In: PARANHOS, S.B. (Coord,) Cana-de-açúcar: cultivo e utilização. Campinas: Fundação Cargill, 1987, v.1, cap.1, p.56-87.

MALAVOLTA, E. Fertilizing for high yield sugarcane. Basel: IPI, 1994. 104p. (Bulletin, 14). 
MALAVOLTA, E.; HAAG, N.P. Nutrição e adubação. In: Malavolta, E. (Ed.). Cultura e adubação da cana-de-açúcar. São Paulo: Instituto Brasileiro da Potassa, 1964. p.237-278.

MARSCHNER, H.; KIRKBY, E.A.; CAKMAK, I. Effect of mineral status on shootroot partitioning of photoassimilates and cycling of mineral nutrients. Journal of Experimental Botany, v.47, p.1255-1263, 1996.

McNEILL, A.M.; ZHU, C.; FILLERY, R.P. Use of in situ ${ }^{15} \mathrm{~N}$-labelling to estimate the total below-ground nitrogen of pasture legumes in intact soil-plant systems. Australian Journal Agriculture Research, v.48, p.295-304, 1997.

NOORDWIJK, M. van; FLORIS, J.; Loss of dry weight during washing and storage of root samples. Plant and Soil, v.53, p.239-243, 1979.

ORLANDO FILHO, J.; HAAG, H.P.; ZAMBELLO JUNIOR, E. Crescimento e absorção de macronutrientes pela cana-de-açúcar, variedade CB41-76, em função da idade, em solos do Estado de São Paulo. Boletim Técnico Planalsucar, v.2, n.1, p.1-128, 1980.

ORLANDO FILHO, J.; RODELLA, A.A.; BELTRAME, J.A.; LAVORENTI, N.A. Doses, fontes e formas de aplicação de nitrogênio em cana-de-açúcar. STAB Açúcar, Álcool e Subprodutos, v.17, n.4, p.39-41, 1999.

PAULINO, A.F.; MEDINA, C.C.; AZEVEDO, M.C.B.; SILVEIRA, K.R.P.; TREVISAN, A.A.; MURATA, I.M. Escarificação de um latossolo vermelho na póscolheita de soqueira de cana-de-açúcar. Revista Brasileira de Ciência do Solo, v.28, n.5, p.911-917, 2004. 
PENATTI, C.P.; DONZELLI, J.L.; FORTI, J.A. Doses de nitrogênio em cana-planta. In: SEMINÁRIO DE TECNOLOGIA AGRONÔMICA, 7., Piracicaba, 1997. Anais Piracicaba: Centro de Tecnologia da COPERSUCAR, 1997. p.340-349.

QUEIROZ-VOLTAN, R.B.; PRADO, H.; MORETTI, F.C. Aspectos estruturais de raízes de cana-de-açúcar sob efeito da compactação do solo. Bragantia, v.57, n.1, p.49-55, 1998.

RAIJ, B. van. Fertilidade do solo e adubação. Piracicaba: Editora Agronômica Ceres, 1991. 343p.

RHEINHEIMER, D.S.; ANGHINONI, I. Distribuição do fósforo inorgânico em sistemas de manejo de solo. Pesquisa Agropecuária Brasileira, v.36, n.1, p.151160, 2001.

ROCHECOUSTE, E. Weed control in sugar cane. Réduit: Mauritius Sugar Industry Research Institute, 1967. 117p.

RODRIGUES, R. Século XXI, o novo tempo da agroenergia renovável. Visão Agrícola, v.1, n.1, p.4-7, jan-jun, 2004.

RUF, M.; BRUNNER, I. Vitality of tree fine roots: reevaluation of the tetrazolium test. Tree Physiology, v.23, p.257-263, 2003.

RUSSEL, C.A.; FILLERY, I.R.P. In situ ${ }^{15} \mathrm{~N}$ labeling of lupin below-ground biomass. Australian Journal Agricultural Research, v.47, p.1035-1046, 1996.

SALATA, J.C.; ARMENE, J.C.; DEMATTE, J.L.I. Influência do tipo de sulcador no desenvolvimento do sistema radicular e produtividade da cana-de-açúcar. STABAçúcar, Álcool e Subprodutos, v.5, n.4, p.12-18, 1987. 
SAMPAIO, E.V.S.B; SALCEDO, I.H. Eficiência de utilização de uréia- ${ }^{15} \mathrm{~N}$ por canaplanta e três socas em tabuleiro costeiro de Pernambuco. In: CONGRESSO NACIONAL DA STAB, 4., CONVENÇÃO DA ACTALAC, 7., Olinda, 1987. Anais Olinda: STAB, 1987. p.46-49.

SAS INSTITUTE. SAS/STAT user's guide; release 6.08 ed. Cary, 1991. 1028p.

STEPONKUS, P.L.;. LANPHEAR F.O. Refinement of the triphenyl tetrazolium chloride method for determining cold injury. Plant Physiology, n.42, p.1423-1426, 1967.

TAKAHASHI, D.T. Six years studies on nitrogen utilization by sugar cane plant using ${ }^{15} \mathrm{~N}$ as a tracer. In: INTERNATIONAL SOCIETY OF SUGARCANE TECHNOLOGISTS CONGRESS, 10. Honolulu, 1959. Proceedings Amsterdam: Elsevier Publishing, 1960. p.377-389.

THORNE, G. Nutrient uptake from leaf sprays by crops. Field Crops Abstracts, v.8, n.3, p.147-151, 1955.

TRIVELIN, P.C.O. Utilização do nitrogênio pela cana-de-açúcar: três casos estudados com o uso do traçador ${ }^{15} \mathrm{~N}$. Piracicaba, 2000. 143p. Tese (Livre-docência) - Centro de Energia Nuclear na Agricultura, Universidade de São Paulo.

TRIVELIN, P.C.O.; COLETI, J.T.; LARA CABEZAS, W.A.R. Efeito residual na soqueira de cana-de-açúcar do nitrogênio da uréia aplicada por via foliar na canaplanta. In: SEMINÁRIO SOBRE TÉCNICAS NUCLEARES NA PRODUÇÃO DE PLANTAS AGRÍCOLAS, Piracicaba, 1984. Anais Piracicaba: CENA, 1984. p.119-124. 
TRIVELIN, P.C.O.; COLETI, J.T.; MATSUI, E. Absorção e perdas de uréia aplicada por via foliar na cana-de-açúcar (Saccharum spp), considerando a ocorrência de chuvas a diferentes intervalos de tempo da aplicação. STAB-Açúcar, Álcool e Subprodutos, v.3, n.3, p.12-16, 1985.

TRIVELIN, P.C.O.; VITTI, A.C.; OLIVEIRA, M.W.; GAVA, G.J.C.; G. A. SARRIÉS Utilização de nitrogênio e produtividade da cana-de-açúcar (cana-planta) em solo arenoso com incorporação de resíduos da cultura. Revista Brasileira de Ciência do Solo, v.26, n.3, p.636-646, 2002.

TRIVELIN, P.C.O.; CAMARGO, P.B.; LIBARDI, P.L.; MORAES, S.O.; LARA CABEZAS, W.A.R.; PALHARES, A.L. Dinâmica do $\mathrm{N}$ dos fertilizantes: uréia $\left({ }^{15} \mathrm{~N}\right)$ e aquamônia $\left({ }^{15} \mathrm{~N}\right)$ incorporados ao solo na cultura da cana-de-açúcar. Piracicaba: FEALQ; CENA, 1988b. 84p. (Relatório Técnico).

TRIVELIN, P.C.O.; CARVALHO, J.G.; SILVA, A.Q.; PRIMAVESI, A.C.P.A.; CAMACHO, E.; EIMORI, I.E.; GUILHERME, M.R. Adubação foliar de cana-deaçúcar (Saccharum spp). Absorção e translocação de uréia- ${ }^{15}$ N. Energia Nuclear e Agricultura, v.9, n.2, p.52-65, 1988a.

UNICA. Estatísticas. Produção de Cana-de-açúcar. http://www.unica.com.br. (10 de novembro de 2004).

VASCONCELOS, A.C.M. O sistema radicular da cana-de-açúcar e a expressão do potencial de produção. STAB-Açúcar, Álcool e Subprodutos, v.21, n.2, p.20, 2002a.

VASCONCELOS, A.C.M. Desenvolvimento do sistema radicular e da parte aérea de socas de cana-de-açúcar sob dois sistemas de colheita: crua mecanizada e queimada manual. Jaboticabal, 2002b. 140p. Tese (Doutorado) Faculdade de Ciências Agrárias e Veterinárias - UNESP. 
VASCONCELOS, A.C.M.; CASAGRANDE, A.A.; PERECIN, D.; JORGE, L.A.C.; LANDELL, M.G.A. Avaliação do sistema radicular de cana-de-açúcar por diferentes métodos. Revista Brasileira de Ciência do Solo, v.27, n.3, p.849-858, 2003.

VITTI, A.C. Utilização pela cana-de-açúcar (cana planta) do nitrogênio da uréia $\left({ }^{15} \mathrm{~N}\right)$ e do mineralizado no solo em sistemas de manejo com e sem a queima. Piracicaba, 1998. 93p. Dissertação (Mestrado) - Centro de Energia Nuclear na Agricultura, Universidade de São Paulo.

WITTWER, S.H.; TEUBNER, F.G. Foliar absorption of mineral nutrients. Annual Review of Plant Physiology, v.10, n.1, p.13-32, 1959.

YANG, S.J. Soil physical properties and the growth of ratoon cane as influenced by mechanical harvesting. In: CONGRESS OF INTERNATIONAL SOCIETY OF SUGAR CANE TECHNOLOGISTS, São Paulo,1977. Proceedings São Paulo: ISSCT, 2001. p.835-847.

ZEBARTH, B.J.; ALDER, V.; SHEARD, R.W. In situ labelling of legume residues with a foliar application af a ${ }^{15} \mathrm{~N}$-enriched urea solution. Communications in Soil Service and Plant Analysis, v.22, p.437-447, 1991. 